\title{
FRAÇÃO ORGÂNICA DE BIOSSÓLIDOS E EFEITO NO ESTOQUE DE CARBONO E QUALIDADE DA MATÉRIA ORGÂNICA DE UM LATOSSOLO CULTIVADO COM EUCALIPTO
}

\section{CRISTIANO ALBERTo DE ANDRADE}

Tese apresentada à Escola Superior de Agricultura "Luiz de Queiroz", Universidade de São Paulo, para obtenção do título de Doutor em Agronomia, Área de Concentração: Solos e Nutrição de Plantas.

P I R A C I C A B A

Estado de São Paulo - Brasil

Abril - 2004 


\title{
FRAÇÃO ORGÂNICA DE BIOSSÓLIDOS E EFEITO NO ESTOQUE DE CARBONO E QUALIDADE DA MATÉRIA ORGÂNICA DE UM LATOSSOLO CULTIVADO COM EUCALIPTO
}

\section{CRISTIANO ALBERTO DE ANDRADE}

Engenheiro Agrônomo

\author{
Orientador: Prof. Dr. CARLOS CLEMENTE CERRI
}

Tese apresentada à Escola Superior de Agricultura "Luiz de Queiroz", Universidade de São Paulo, para obtenção do título de Doutor em Agronomia, Área de Concentração: Solos e Nutrição de Plantas.

P I R A C I C A B A

Estado de São Paulo - Brasil

Abril - 2004 
Dados Internacionais de Catalogação na Publicação (CIP) DIVISÃO DE BIBLIOTECA E DOCUMENTAÇÃO - ESALQ/USP

Andrade, Cristiano Alberto de

Fração orgânica de biossólidos e efeito no estoque de carbono e qualidade da matéria orgânica de um latossolo cultivado com eucalipto / Cristiano Alberto de Andrade. - - Piracicaba, 2004.

$121 \mathrm{p}$.

Tese (doutorado) - Escola Superior de Agricultura Luiz de Queiroz, 2004. Bibliografia.

1. Biossólidos 2. Carbono 3. Eucalipto 4. Latossolo 5. Lodo de esgoto Matéria orgânica do solo 7. Química do solo 8. Solos (Qualidade) I. Título 
"É preferível arriscar coisas grandiosas, alcançar triunfos e glórias, mesmo expondo-se à derrota, do que formar fila com os pobres de espírito que não gozam muito e nem sofrem muito, porque vivem na penumbra obscura e cinzenta dos que não conhecem nem a vitória, nem a derrota"

(Paulo Nogueira de Camargo e Ody Silva, 1975)

Aos meus pais Antonio e Rute, e ao meu irmão Cassio, por me mostrarem, desde muito cedo, o verdadeiro sentido da palavra família, OFEREÇO

\begin{abstract}
À Ana, pelo apoio irrestrito na concretização de minhas aspirações, pela sabedoria e cumplicidade, enfim, pelo toque adicional de felicidade em minha vida,
\end{abstract}




\section{AGRADECIMENTOS}

Ao Prof. Dr. Carlos Clemente Cerri, pela orientação, voto de confiança e amizade, meu muito obrigado;

À Prof. Dra. Maria Emilia Mattiazzo, pela convivência agradável de dez anos, construída com trabalho, companheirismo e amizade;

Ao meu "fiel escudeiro" Claudeir de Oliveira, pela amizade e pelo esforço intenso para realização deste trabalho;

Aos meus tios Bolivar e Rosimeire, e aos meus primos Evandro e Elaine, pelo apoio;

Aos companheiros Marcelino Guedes, Marcelo Alves e Janaina do Carmo, pela sincera amizade e pelas conversas sábias ao longo desses anos;

Aos amigos de ontem e de hoje, Roberto Konno, Pedro Plese, Luciano Vaz, Dauton Cappi, Alex Paulus e Tatiane, com quem dividi momentos alegres na vida em república; Aos estagiários Fernando Limonge, André Luis, Matheus Bayer e Vítor pelo auxílio em algumas etapas do trabalho e, sobretudo, pela amizade;

Aos alunos de graduação Camila Cenciani e Diléia dos Santos, com que tive a agradável oportunidade de trabalhar;

Aos amigos que conheci no Departamento de Química da ESALQ/USP, Adriana, Édna, Fábio Prata, Fernando, Tadeu, Genelício, Barizon, Paula Parcker, Paula Prezzotto, Marta, Márcio, Letícia, Lúcia, Fabiana, Susian, Estêvão e Jonas, meu muito obrigado; Às pesquisadoras Dra. Marisa C. Piccolo e Dra. Brigitte Feighl, e aos amigos Norberto, Caio, Karine, Marcelo e Lavres, que participam ou participaram do grupo de trabalho de Rondônia, pelos momentos alegres e pelos ensinamentos de grupo;

Ao Prof. Dr. Fábio Poggiani, pela amizade e pela chance de novamente integrar o grupo de pesquisa do Projeto SABESP; 
Ao Prof. Dr. Ricardo Ferraz de Oliveira, pela consideração e oportunidade de trabalharmos juntos;

Aos técnicos do Laboratório de Biogeoquímica Ambiental do CENA/USP, Luiz Hiroshi, Lílian, Sandra e Dagmar, pelos laços de amizade criados e pelo apoio nas análises;

Ao Dr. Adibe Luiz Abdalla do Laboratório de Nutrição Animal do CENA/USP, pelo apoio nas análises;

À técnica de laboratório Regina Peçanha, pelo atendimento sempre gentil, pelo esforço e dedicação na realização das análises;

Ao Dr. Jean Ometto, do Laboratório de Ecologia Isotópica do CENA/USP, pela amizade, pelo apoio técnico nas análises e, sobretudo, pelo caráter profissional que todo pesquisador público deve ter;

Às secretárias Nancy, Mara, Angélica, Armelinda e Ana, por “me socorrerem” sempre que necessário, com sorriso nos lábios;

Às bibliotecárias Eliana e Silvia, pela atenção e atendimento na revisão deste trabalho;

À Coordenação do Curso de Pós-Graduação em Solos e Nutrição de Plantas da ESALQ/USP, pela oportunidade concedida;

À CAPES, pela concessão de três anos de bolsa para o cumprimento dessa etapa;

A todos os amigos do curso de Pós-Graduação da ESALQ, pelos momentos alegres e ensinamentos ao longo desses anos;

A todos os brasileiros pagadores de impostos, principalmente aqueles financeiramente menos favorecidos, que muitas vezes sem dinheiro para financiar os estudos de seus próprios filhos, concederam a este “estranho" a oportunidade de cursar uma UNIVERSIDADE PÚBLICA, meus sinceros agradecimentos. 


\section{SUMÁRIO}

Páginas

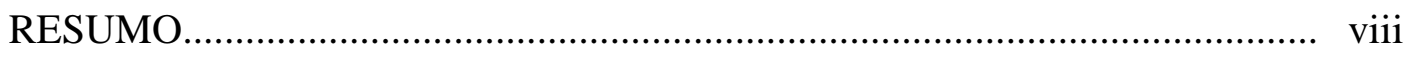

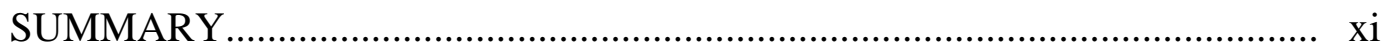

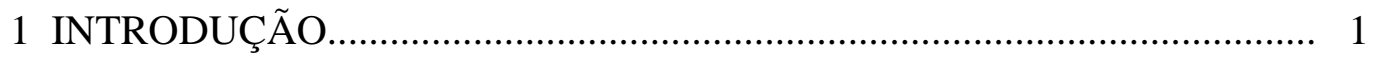

2 REVISÃO DE LITERATURA............................................................. 3

2.1 Uso agrícola de biossólidos............................................................... 3

2.2 Fração orgânica de biossólidos e degradação no solo.................................. 6

2.3 Capacidade de troca catiônica de biossólidos e solos tratados.................... 12

2.4 Estoques de carbono em solos tratados com biossólidos e qualidade da matéria orgânica do solo....................................................................... 14

3 COMPOSIÇÃO QUÍMICA DA MATÉRIA ORGÂNICA DE BIOSSÓLIDOS E RELAÇÃO COM A DEGRADAÇÃO APÓS APLICAÇÃO NO SOLO................................................................... 17

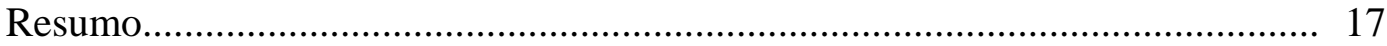

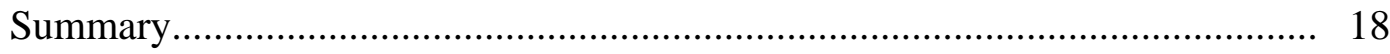

3.1 Introdução........................................................................................ 20

3.2 Material e Métodos............................................................................. 22

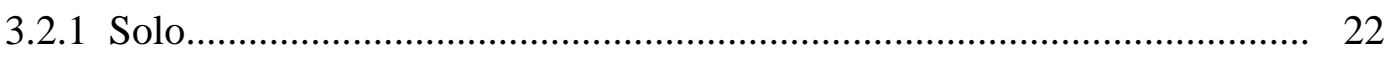

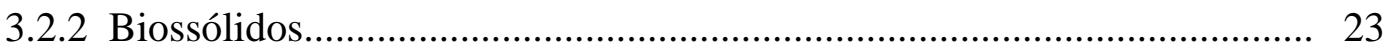

3.2.3 Caracterização química da matéria orgânica dos biossólidos.................... 25

3.2.4 Experimento para avaliação da degradação dos biossólidos................... 27

3.2.5 Forma de análise dos resultados..................................................... 27

3.3 Resultados e discussão........................................................................ 31

3.3.1 Caracterização química da matéria orgânica dos biossólidos.................. 31

3.3.1.1 Carbono, nitrogênio e fósforo.................................................................................... 31 
Páginas

3.3.1.2 Fracionamento químico do carbono. 35

3.3.1.3 Compostos orgânicos................................................................................................... 37

3.3.2 Degradação da matéria orgânica dos biossólidos....................................... 42

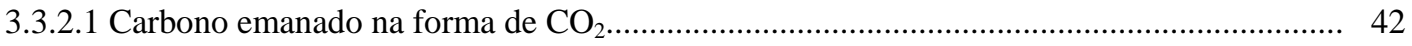

3.3.2.2 Taxa de degradação da matéria orgânica dos biossólidos....................................................... 44

3.3.2.3 Cinética química da degradação da matéria orgânica........................................................ 46

3.3.3 Relação entre degradação e composição química da matéria orgânica dos

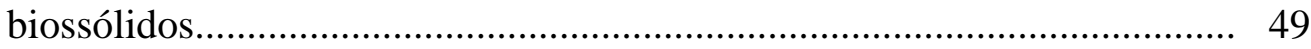

3.4 Conclusões........................................................................................ 58

4 ESTOQUE DE CARBONO E QUALIDADE DA MATÉRIA ORGÂNICA DE UM LATOSSOLO TRATADO COM BIOSSÓLIDO E SOB CULTIVO

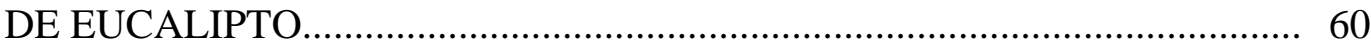

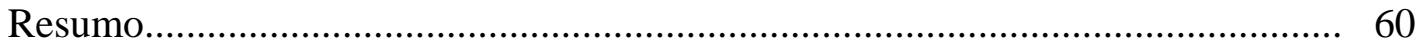

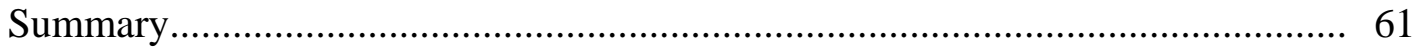

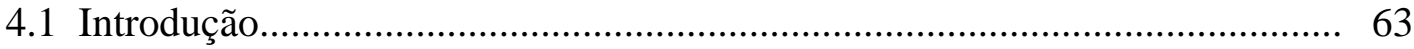

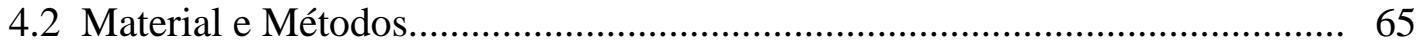

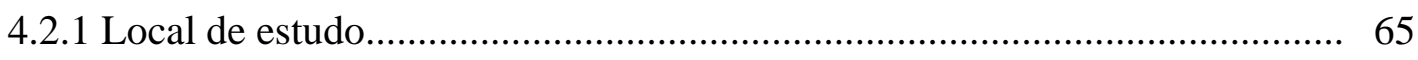

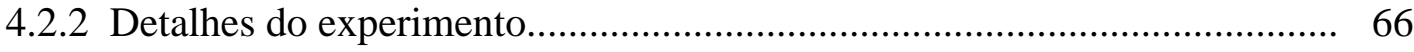

4.2.3 Amostragem do solo e análises químicas............................................... 67

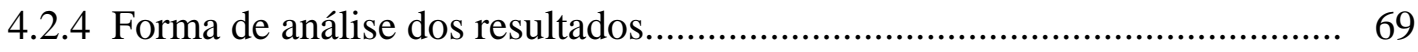

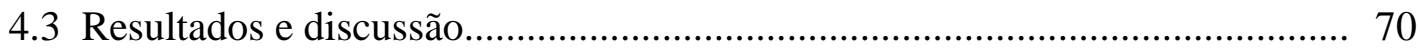

4.3.1 Teores de carbono e nitrogênio no solo................................................... 70

4.3.2 Estoques de carbono e nitrogênio no solo............................................... 75

4.3.3 Frações do carbono orgânico do solo..................................................... 78

4.3.4 Compostos orgânicos........................................................................ 82

4.3.5 Capacidade de troca catiônica (CTC) ..................................................... 90

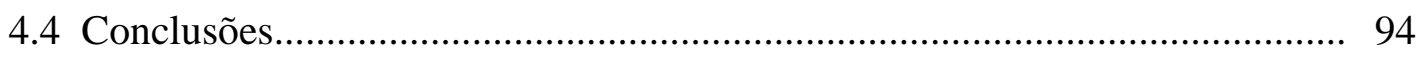

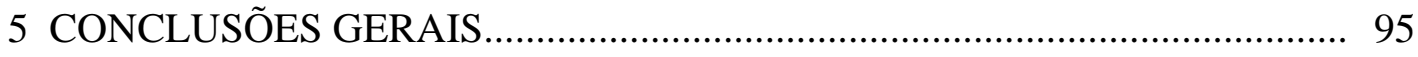

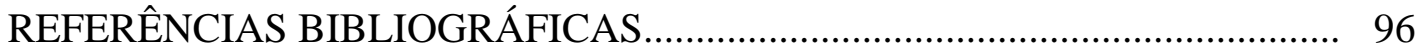

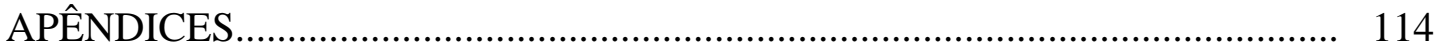




\title{
FRAÇÃO ORGÂNICA DE BIOSSÓLIDOS E EFEITO NO ESTOQUE DE CARBONO E QUALIDADE DA MATÉRIA ORGÂNICA DE UM LATOSSOLO CULTIVADO COM EUCALIPTO
}

\author{
Autor: CRISTIANO ALBERTO DE ANDRADE \\ Orientador: Prof. Dr. CARLOS CLEMENTE CERRI
}

\section{RESUMO}

O presente trabalho teve como objetivo caracterizar o processo de decomposição da fração orgânica de biossólidos, após aplicação no solo, correlacionando com a composição química inicial da matéria orgânica (MO) dos resíduos. Também foi objetivo, quantificar, no campo, o efeito de um biossólido alcalino na MO de um Latossolo cultivado com eucalipto, após cinco anos da aplicação de doses do resíduo ou de fertilizantes minerais. A degradação da MO de biossólidos foi avaliada por meio da incubação de misturas de solo e cinco biossólidos, em dose correspondente a $40 \mathrm{t} \mathrm{ha}^{-1}$, com quantificação do $\mathrm{CO}_{2}$ emitido durante um período de 70 dias. Os biossólidos foram escolhidos em função de diferenças no sistema de tratamento de esgotos e/ou condicionamento químico para desidratação e/ou etapa complementar visando melhor adequação ao uso agrícola: BAC - biossólido anaeróbio condicionado com cal e cloreto férrico e desidratado mecanicamente; BAP - biossólido anaeróbio condicionado com polímero sintético e desidratado mecanicamente; BAS - biossólido anaeróbio seco termicamente; BLP = biossólido proveniente de lagoas de estabilização, condicionado com polímero sintético e desidratado mecanicamente; e CL - composto de 
lodo de esgoto obtido por compostagem em pilhas aeradas após mistura do BLP com bagaço de cana-de-açúcar e restos de poda urbana. A MO dos biossólidos foi analisada quanto aos teores totais, orgânicos e inorgânicos de C, N e P; teor de carbono solúvel em água; frações do carbono orgânico em função de graus de oxidação; e teores de açúcares solúveis, proteína bruta, lipídeos, hemicelulose, celulose, lignina, taninos e fenóis. Em todos os biossólidos o $\mathrm{C}$ e o $\mathrm{N}$ predominaram em compostos orgânicos, enquanto que a partição do P, entre compostos orgânicos e inorgânicos, foi função do tratamento dos esgotos e/ou condicionamento para desidratação. As taxas de degradação dos biossólidos foram, de modo geral, baixas e os menores valores foram observados para o BLP e o CL, provavelmente devido a maior estabilidade da MO desses resíduos. Em todos os biossólidos houve expressiva participação do compartimento protéico como constituinte da MO, apresentando valores médios entre 25 e 46 \% do total de MO. A proteína bruta foi o parâmetro que melhor correlacionou com a taxa de degradação dos biossólidos ao final de 70 dias de incubação $\left(r=0,999\right.$ e Prob. $>t$ inferior a $\left.10^{-4}\right)$, sendo promissora sua utilização no sentido de previsão da degradação da MO de biossólidos após aplicação no solo. O estudo de caso, no campo, foi desenvolvido em área com Eucalyptus grandis plantado em março de 1998 e fertilizado, quatro meses depois, com biossólido ou fertilizantes minerais. Os tratamentos avaliados foram: (i) Controle; (ii) Fertilização Mineral com N, P, K, B e Zn (Fert. Mineral) ; (iii) $10 \mathrm{t} \mathrm{ha}^{-1}$ de biossólido + K (10 $\left.\mathrm{t} \mathrm{há}^{-1}\right)$; (iv) $20 \mathrm{t} \mathrm{ha}^{-1}$ de biossólido $+\mathrm{K}\left(20 \mathrm{t} \mathrm{ha}^{-1}\right)$; e (v) $40 \mathrm{t} \mathrm{ha}^{-1}$ de biossólido $+\mathrm{K}$ (40 $\mathrm{t} \mathrm{ha}^{-1}$ ). Em setembro de 2003 foram coletadas amostras de solo das camadas 0-5, 5-10, 10-20, 20-30 e 30-60 cm. Em todas as amostras foram determinados os teores totais de $\mathrm{C}$ e $\mathrm{N}$ e a densidade aparente. Nas amostras coletadas até $20 \mathrm{~cm}$ de profundidade, foram feitas determinações de $\mathrm{pH}$, frações de C-orgânico por graus de oxidação, teores de alguns compostos orgânicos (açúcares solúveis, proteína bruta, lipídeos, hemicelulose, celulose e lignina), CTC a pH 7,0 e CTC ao pH natural. Os resultados praticamente não evidenciaram alterações na $\mathrm{MO}$ do solo, após cinco anos da aplicação do biossólido ou de fertilizantes minerais. Os estoques médios de C e N, até $60 \mathrm{~cm}$ de profundidade, foram iguais a 92,86 e 4,41 t ha-1 $50 \%$ do total de $\mathrm{C}$ esteve no compartimento denominado lábil, o que é típico de 
sistemas naturais ou manejados onde há o favorecimento ao retorno de resíduos vegetais ao solo. Dos compostos orgânicos determinados, houve variação significativa somente do teor de lignina na MO do solo $(0-5 \mathrm{~cm})$, com maiores valores nos tratamentos 40 t ha ${ }^{-1}$ de biossólido e Fert. Mineral, sendo tais resultados atribuídos a maior deposição de folhas nesses tratamentos e à natureza recalcitrante da lignina no ambiente. A CTC $(\mathrm{pH}$ natural) mostrou-se mais dependente dos valores $\mathrm{pH}$ do solo, do que dos teores de $\mathrm{C}$, não evidenciando benefícios da MO dos biossólidos nessa propriedade, somente de forma indireta pela elevação do $\mathrm{pH}$ do solo tratado. 


\title{
ORGANIC FRACTION OF THE BIOSOLIDS AND EFFECT ON CARBON STOCKS AND ORGANIC MATTER QUALITY IN AN OXISOL PLANTED WITH EUCALYPTUS
}

\author{
Author: CRISTIANO ALBERTO DE ANDRADE \\ Adviser: Prof. Dr. CARLOS CLEMENTE CERRI
}

\section{SUMMARY}

The aim of this work was to characterize the organic fraction decomposition process of the biosolids in soil, correlating to initial organic matter (OM) composition of residue. Another objective was quantify, under field conditions, the effect of alkaline biosolid on Oxisol OM, in a site planted with eucalyptus and after five years of the residue application or mineral fertilizers application. The OM decomposition of the biosolids was evaluated using the incubation of soil mixtures and five biosolids, in a rate of $40 \mathrm{t} \mathrm{ha}^{-1}$, with quantification of the $\mathrm{CO}_{2}$ emitted during a period of 70 days. The biosolids were chosen in function of the treatment system of sewage and/or chemical conditioning for biosolid dehydration and/or complementary stage to adequate the residue for agricultural use: BAC - anaerobic biosolid conditioned with lime and ferric chloride and mechanically dehydrated; BAP - anaerobic biosolid conditioned with synthetic polymers mechanically dehydrated; BLP - biosolid originated in stabilization ponds and conditioned with synthetic polymers mechanically dehydrated; CL - sewage sludge compost originated from aerated pile composting of a mixture of BLP, crushed sugar cane and remains of urban pruning. The OM of the biosolids was analyzed regarding the total, organic and inorganic contents of $\mathrm{C}, \mathrm{N}$ and $\mathrm{P}$; content 
of water-soluble carbon; oxidizible organic carbon fractions; and contents of soluble sugars, crude protein, lipids, hemicellulose, cellulose, lignin, tannins and phenols. All biosolids had $\mathrm{C}$ and $\mathrm{N}$ predominance in organic compounds, while the $\mathrm{P}$ distribution in organic and inorganic compounds was as a function of the treatment used in the Plants. The decomposition rates of the biosolids, in general, were low and the lowest values were observed for BLP and CL, probably due to higher OM stability of the residues. There was expressive participation of protein pool in all biosolids, with mean values between 25 and $46 \%$ of total OM. The crude protein was the parameter that better correlated with biosolid degradation rate at the end of 70 days of incubation $(r=0.999$ e Prob. $>\mathrm{t}$ lower than $10^{-4}$ ), being promising its use in order to expect the biosolid OM decomposition after soil application. The study case, on the field, was developed in an area with Eucalyptus grandis planted on March 1998 and fertilized, after four months, with biosolid or mineral fertilizers. The appraised treatments were: (i) Control; (ii) Mineral Fertilization with N, P, K, B and Zn (Mineral Fert.); (iii) $10 \mathrm{t} \mathrm{ha}^{-1}$ of biosolid + $\mathrm{K}\left(10 \mathrm{t} \mathrm{ha}^{-1}\right)$; (iv) $20 \mathrm{t} \mathrm{ha}^{-1}$ of biosolid $+\mathrm{K}\left(20 \mathrm{t} \mathrm{ha}^{-1}\right)$; and (v) $40 \mathrm{t} \mathrm{ha}^{-1}$ of biosolid $+\mathrm{K}$ $\left(40 \mathrm{t} \mathrm{ha}^{-1}\right)$. Soil samples were taken from 0-5, 5-10, 10-20, 20-30 and 30-60 cm soil depths, on September 2003. Total amounts of $\mathrm{C}$ and $\mathrm{N}$ and bulk density were determined in all samples. In the samples collected up to $20 \mathrm{~cm}$ of depth, were made $\mathrm{pH}$ determinations, oxidizible organic carbon fractions, amounts of some organic compounds (soluble sugars, crude protein, lipids, hemicellulose, cellulose and lignin), CEC the $\mathrm{pH} 7,0$ and CEC to the natural pH. In general, the results did not show differences in the soil OM, after five years of the biosolid application or mineral fertilizers application. The mean values of $\mathrm{C}$ and $\mathrm{N}$ stocks up to $60 \mathrm{~cm}$ soil depth were the same to 92.86 and $4.41 \mathrm{t} \mathrm{ha}^{-1}$, respectively. About $50 \%$ of the total $\mathrm{C}$ was in the fraction denominated labile, which is typical of natural systems or managed systems where the return of plant residues to the soil is allowed. From the determined organic compounds, only the lignin content (0-5 cm depth) was different between the treatments, with higher concentrations in the treatments $40 \mathrm{t} \mathrm{ha}^{-1}$ of biosolid and Mineral Fert., probably because the largest depositions of leaves on soil surface in these treatments and the natural slow decay of lignin. The CEC (natural $\mathrm{pH}$ ) values were more dependent on 
soil $\mathrm{pH}$, than on the soil $\mathrm{C}$ content. Benefits of OM biosolids in soil CEC were not observed. 


\section{INTRODUÇÃO}

A matéria orgânica do solo (MOS) tem sido por muito tempo objeto de investigações no ramo das ciências do solo e ambientais. Atribui-lhe, atualmente, reconhecido papel em processos físicos, químicos e biológicos edáficos, fundamentais para a manutenção da produtividade agrícola, sustentabilidade de ecossistemas naturais ou manejados e equilíbrio global do ciclo do carbono. A busca por alternativas adequadas de manejo da MOS em cenários sociais e edafoclimáticos variáveis constitui em novo foco de atenção para os cientistas. Nesse sentido, em regiões agrícolas próximas a centros urbanos e onde há o uso intensivo dos recursos naturais, em especial do solo, a reciclagem agrícola de lodos de esgoto (biossólidos) como fonte de matéria orgânica para o solo aparece como alternativa promissora e recomendável (Canellas et al., 2001).

A utilização agrícola de biossólidos encontra-se, de algum modo, alicerçada na degradação da fração orgânica do resíduo após aplicação no campo. O fornecimento de nutrientes como nitrogênio e fósforo, via doses de biossólidos, efeitos no $\mathrm{pH}$ e capacidade de troca catiônica (CTC) de solos, melhoria na agregação do solo e seqüestro de carbono (C), são alguns exemplos relacionados com a decomposição do resíduo no ambiente. Embora exista um aparente consenso quanto a importância das reações de degradação do C orgânico e de síntese de substâncias húmicas a partir do material orgânico introduzido no sistema, dados da literatura são pouco conclusivos acerca da qualidade da fração orgânica de biossólidos, sua dinâmica após adição ao solo e efeitos na magnitude do estoque de $\mathrm{C}$ e qualidade da MOS de áreas tratadas. A divulgação, uso e aperfeiçoamento de ferramentas analíticas menos convencionais, como métodos espectroscópicos, vêm promovendo avanços singulares no referido campo científico durante as últimas décadas. Porém, mesmo abordagens de estudo convencionais em 
MOS apresentam ainda potencial para auxiliar na compreensão dos processos relacionados com a mineralização do C orgânico de biossólidos após aplicação no solo, dada a carência de trabalhos na literatura especializada.

Diante exposto, o presente estudo foi realizado, tendo como objetivos: (i) quantificar a degradação de biossólidos após aplicação no solo e correlacionar com a composição da fração orgânica dos resíduos; e (ii) avaliar quanti-qualitativamente a MO de um solo sob plantio de eucalipto e tratado com doses de biossólido.

A tese está dividida em três capítulos: dois apresentados na forma de trabalhos científicos para publicação em revistas científicas da área e um de revisão de literatura acerca dos temas pertinentes ao estudo. O primeiro trabalho científico se refere a caracterização da fração orgânica ou MO de cinco biossólidos e correlação com as respectivas taxas de degradação obtidas em experimento respirométrico, identificando alguns parâmetros promissores na estimativa da biodegradabilidade desses resíduos após aplicação no solo. O segundo trabalho científico trata de um caso de estudo em área sob cultivo de eucalipto, com cinco anos de idade, que recebeu doses de um biossólido alcalino três meses após o plantio das mudas. Nesse trabalho são investigados os efeitos das doses de biossólido no estoque de carbono e nitrogênio do solo, nas concentrações de alguns compostos orgânicos presentes e na CTC do solo tratado. 


\section{REVISÃO DE LITERATURA}

\subsection{Uso agrícola de biossólidos}

Modelos de desenvolvimento econômico e social adotados por inúmeros países têm exposto parcela expressiva da população mundial aos reflexos catastróficos de uma exploração desordenada e insustentável do meio ambiente. Em âmbito global atualmente se discutem as causas, os efeitos e as soluções para o aquecimento do planeta e alterações nos padrões climáticos. Regionalmente, e não menos importante, a poluição de rios e a degradação dos solos são problemas graves que afetam a qualidade de vida de toda uma população local, em especial dos economicamente menos favorecidos, cujas opções de moradia, poder de consumo e acesso a medicamentos são restritos. Também é regionalmente que se vislumbra as principais soluções para os problemas ambientais, uma vez que a efetivação prática de planos de ação ocorre freqüentemente nessa escala. Nesse sentido, a geração e descarte de resíduos têm sido atacada por diversas frentes, de modo a minimizar sua geração e selecionar técnicas ecologicamente favoráveis de reutilização ou destino final dos materiais não passíveis de reuso. Dentre as medidas

práticas atualmente empreendidas encontra-se o tratamento dos esgotos antes da devolução aos corpos d’água receptores. Tal prática, respeitando a capacidade de suporte e resiliência do meio, melhora consideravelmente os índices de qualidade de águas superficiais (Bettiol \& Camargo, 2000). Entretanto, como toda atividade humana gera resíduos, isso não é diferente com relação ao tratamento dos esgotos nas estações, podendo-se citar dentre os resíduos mais problemáticos os lodos de esgoto. Andrade (1999) definiu lodo de esgoto como um resíduo semi-sólido, predominantemente orgânico, com teores variáveis de componentes inorgânicos, originado do tratamento de esgotos domiciliares e/ou industriais. Somente na região metropolitana de São Paulo, a 
companhia de saneamento do estado, SABESP, prevê a produção de cerca de $766 \mathrm{t}$ dia ${ }^{-1}$ de lodo de esgoto (base seca) para o ano de 2015 (Melo \& Marques, 2000).

O descarte final de lodos de esgotos é problema dos mais graves, sendo a disposição em aterros sanitários e a incineração, alternativas utilizadas em muitos países no mundo. Em particular, no Brasil, os lodos de esgoto têm sido colocados em aterros sanitários, mas além do alto custo, 20 a 40\% dos custos operacionais das estações de tratamento de esgotos (Tsutya, 2000), há problemas quanto ao manejo dos resíduos no aterro e contribuição para o rápido esgotamento da capacidade de recepção desses locais.

Em países da Europa, nos EUA e no Japão, parte do lodo de esgoto depois de adequado tratamento químico e/ou biológico e higienização (denominado biossólido), é aplicada em áreas agrícolas (Tabela 1) para o fornecer nutrientes às espécies de interesse agrícola e/ou funcionar como condicionador de características químicas, físicas e biológicas do solo (Melo et al., 1994; Iakimenko et al., 1996). Tavares (2003) cita que o uso agrícola de lodos de esgoto como biossólidos reduziu em cerca de 25\% o custo relacionado ao destino final desse material, em relação a disposição em aterros sanitários. O autor ressalta que a redução de custo só não é maior, porque financeiramente nada se cobra do produtor, ou seja, todo o custo de transporte e assistência técnica é da empresa que gerencia o resíduo. Além de representar benefício econômico, o uso agrícola de biossólidos representa benefício ecológico, pelo retorno ao campo de parte da matéria orgânica, nutrientes e energia exportados para os centros urbanos (Poggiani et al., 2000), e benefício social pela possibilidade de aumento da produtividade das culturas e menor impacto negativo sobre o meio ambiente, esta última em comparação as outras opções de descarte do resíduo. Em solos tropicais muito intemperizados, onde a capacidade de troca catiônica (CTC) é extremamente dependente da MO, o uso agrícola de biossólidos é ainda mais atrativo (Melo et al., 1994). 
Tabela 1. Produção anual (base seca), uso e disposição de lodos de esgoto em países da comunidade européia, nos EUA e no Japão

\begin{tabular}{cccccccc}
\hline Países & Ano & $\begin{array}{c}\text { Produção } \\
\text { anual }\end{array}$ & Aterro & Incineração & Oceano & Agricultura & Outros \\
\hline Bélgica & 1994 & 35 & 43 & ------ & ------ & 57 & ------ \\
Dinamarca & 1994 & 150 & 29 & 28 & ------ & 43 & ------ \\
França & 1994 & 900 & 53 & 20 & ------ & 27 & ------- \\
Alemanha & 1994 & 2750 & 65 & 10 & ------ & 25 & ------ \\
Grécia & 1994 & 200 & 90 & ------ & ------ & 10 & ------- \\
Irlanda & 1994 & 23 & 34 & ------ & 43 & 23 & ------ \\
Itália & 1994 & 800 & 55 & 11 & ------ & 34 & ------- \\
Luxemburgo & 1994 & 15 & 20 & ------ & ------ & 80 & ------ \\
Países Baixos & 1994 & 280 & 29 & 10 & 8 & 53 & ------- \\
Portugal & 1994 & 200 & 12 & ------ & 8 & 80 & ------ \\
Espanha & 1994 & 300 & 10 & ------ & 29 & 61 & ------- \\
Reino Unido & 1994 & 1500 & 16 & 5 & 28 & 51 & ------- \\
EUA & 1988 & 4112 & 3 & 16 & 6 & 33 & 42 \\
Japão & 1994 & 1413 & 80 & ------- & 1 & 13 & 6 \\
\hline
\end{tabular}

Fonte: Santos (1996).

Para garantir que o uso agrícola do resíduo seja realmente benéfico e ambientalmente seguro, normas regulamentadoras específicas vigoram em diversos países e estados. Dentre as mais conhecidas tem-se a norma norte-americana da Environmental Protecy Agency (Estados Unidos, 1993). Os principais aspectos relacionados ao ambiente e abordados nas normas de modo geral são: declividade da área a ser tratada, distância mínima de nascentes de água e leitos de rio, teores totais de alguns metais pesados no solo e espécie vegetal de interesse. Quanto aos biossólidos, aspectos relacionados a degradação da fração orgânica do resíduo, taxa de mineralização do nitrogênio, teores totais de alguns metais pesados e conteúdo de organismos patogênicos estão presentes no textos normativos. No Estado de São Paulo, respeitando a norma técnica P.4230 da CETESB (CETESB, 1999), têm-se na prática como principais limitantes da dose de biossólido a ser aplicada no campo, as quantidades de 
metais pesados adicionadas com a dose do resíduo e o fornecimento de nitrogênio $(\mathrm{N})$ para a cultura de interesse. Com relação aos primeiros, quando a dose é calculada pelo $\mathrm{N}$, pesquisas nacionais têm evidenciado não haver problemas de fitodisponibilidade no solo ou lixiviação para o lençol freático das espécies químicas potencialmente tóxicas (Bertoncini, 1997; Andrade, 1999; Anjos, 1999, Oliveira, 2000). No caso do N, a preocupação é inerente ao comportamento extremamente móvel das formas inorgânicas do elemento no solo e, por isso, um sincronismo entre a disponibilização de $\mathrm{N}$ do resíduo e a absorção pelas plantas torna-se de fundamental importância. Na Norma P.4230 da CETESB isso é contemplado no cálculo da dose de biossólido a ser aplicada, função da taxa de mineralização do N (TMN) do resíduo e da necessidade do nutriente pela cultura agrícola considerada.

A aplicação de biossólidos a culturas não destinadas ao consumo humano, pelo menos diretamente, é preconizada como forma conservativa de garantia contra efeitos adversos à saúde humana, principalmente com relação a bioacumulação trófica de metais pesados a partir dos solos tratados com o resíduo. Culturas como da cana-de-açúcar, para a indústria de açúcar e álcool, eucalipto, para produção de madeira, celulose e papel, e gramíneas forrageiras como o colonião, visando a obtenção de carvão vegetal, apresentam essa vantagem adicional.

\subsection{Fração orgânica de biossólidos e degradação no solo}

As características gerais de um biossólido variam principalmente com o tipo de esgoto (domiciliar e/ou industrial), época do ano, processo de tratamento na estação, tipo de lodo (primário, secundário, terciário), estabilização e condicionamento final (Melo \& Marques, 2000; Tsutiya, 2001). Alguns parâmetros químicos médios calculados a partir de biossólidos utilizados em experimentos no Estado de São Paulo estão sumarizados na Tabela 2. 
Tabela 2. Valores médios e desvio padrão de alguns parâmetros químicos de interesse agronômico, calculados a partir dos resultados de análises químicas de biossólidos utilizados em experimentos no Estado de São Paulo. Valores expressos no material seco

\begin{tabular}{ccc}
\hline Parâmetro & Unidade & Média \pm Desvio Padrão \\
\hline pH & ----------- & $9,1 \pm 2,3$ \\
C-orgânico & $\mathrm{g} \mathrm{kg}^{-1}$ & $189 \pm 70$ \\
N-total & $\mathrm{g} \mathrm{kg}^{-1}$ & $21,5 \pm 7,0$ \\
C/N & --------- & $9 \pm 3$ \\
P-total & $\mathrm{g} \mathrm{kg}^{-1}$ & $10,8 \pm 6,1$ \\
K-total & $\mathrm{g} \mathrm{kg}^{-1}$ & $1,4 \pm 0,5$ \\
Ca-total & $\mathrm{g} \mathrm{kg}^{-1}$ & $102,8 \pm 75,5$ \\
Mg-total & $\mathrm{g} \mathrm{kg}^{-1}$ & $4,0 \pm 2,3$ \\
S-total & $\mathrm{g} \mathrm{kg}^{-1}$ & $10,1 \pm 4,4$ \\
\hline
\end{tabular}

Fonte: $\quad$ Barreto (1995), Silva (1995), Bertoncini (1997), Pires (1998), Andrade (1999), Anjos (1999), Oliveira (2000), Santos et al. (2002).

Analisando a Tabela 2 pode-se verificar que, em média, o C é o elemento presente em maior concentração nos biossólidos, o que evidencia a participação expressiva do componente orgânico, com teores de MO entre 18 e 50 \% da massa seca (Boyd et al., 1980). A própria constituição dos esgotos domiciliares ajuda a explicar a participação da fração orgânica na massa seca dos biossólidos (Figura 1). 


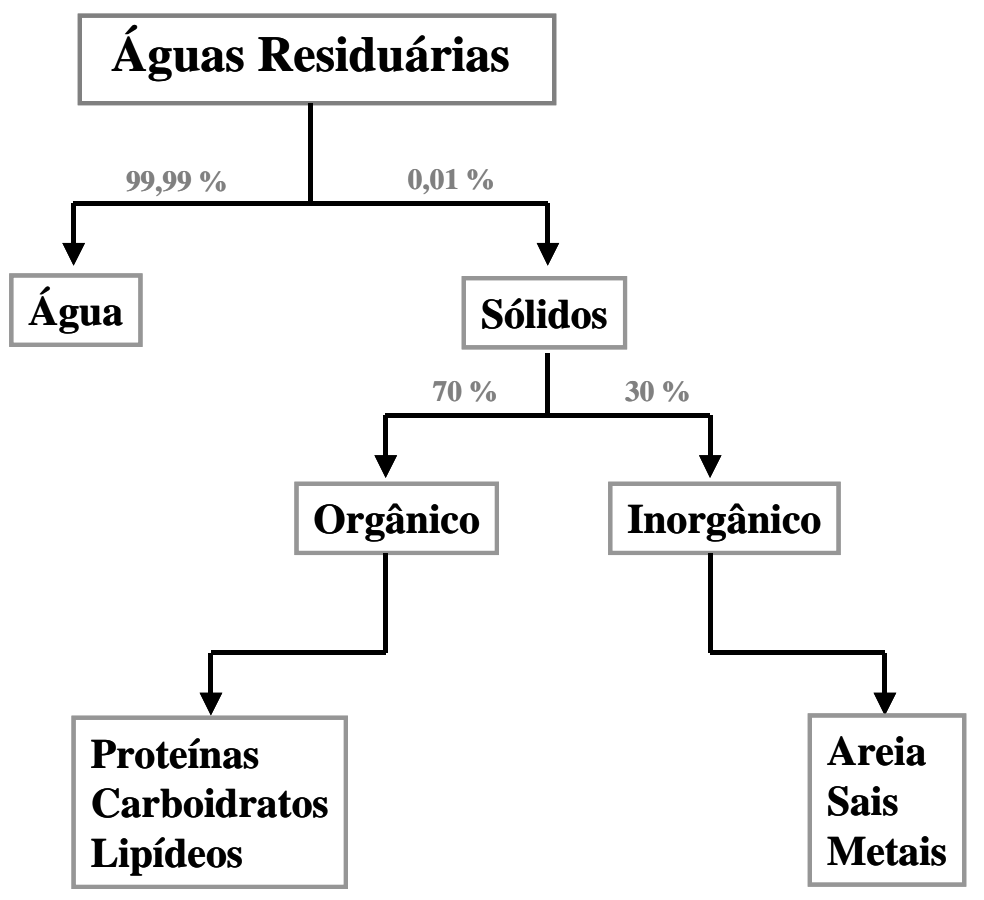

Adaptado de Melo \& Marques (2000)

Figura 1 - Composição típica do esgoto domiciliar

Em função da fração orgânica dos biossólidos, seu uso agrícola como condicionador de solos tem sido recomendado, principalmente pela possibilidade de manutenção ou aumento do teor de C dos solos (Ayuso et al., 1992; Roberts et al., 1988; Boyle \& Paul, 1989; Dìaz-Burgos \& Polo, 1991; Bernal et al., 1998a; Albiach et al., 2001). Porém, tão importante quanto a dose de C adicionada a solos via biossólidos, é a qualidade do material introduzido, isto é, a composição da fração orgânica do resíduo, uma vez que a abundância relativa dos diversos compostos presentes ajuda a determinar sua taxa de degradação após aplicação no campo e por conseguinte a quantidade de C remanescente (Boyd et al., 1980; Hattori \& Mukai, 1986; Ajwa \& Tabatabai, 1994; Bernal et al., 1998a). Alguns dados da literatura evidenciam que diferenças entre solos não têm efeito pronunciado na taxa de degradação de biossólidos, estando esses valores mais relacionados às características do próprio resíduo do que as características edáficas (Terry et al., 1979b). 
Taxas de degradação de biossólidos após aplicação no solo se situam comumente na faixa de 20 a $60 \%$ do C total adicionado (Terry et al., 1979a; Hsieh, et al., 1981; Wiseman \& Zibilske, 1988; Pires et al., 2002; Santos et al., 2002) e de lodos compostados esse valor pode ser inferior a 20\% (Tester et al., 1977; Bernal et al., 1998a), considerando em ambos os casos tempos de avaliação de até 130 dias. Tais valores refletem a presença predominante de compostos orgânicos recalcitrantes, isto é, de difícil degradação biológica no solo (Terry et al., 1979a; Wiseman \& Zibilske, 1988; Mattiazzo et al., 1998; Santos et al., 2002). Em alguns casos a pequena degradabilidade da fração orgânica pode ocorrer devido a imposição de limitações outras à atividade microbiana edáfica, como por exemplo a elevação dos teores de metais pesados (Ajwa \& Tabatabai, 1994; Iakimenko et al., 1996) e/ou concentração de sais solúveis no solo (Carmo, 2000), em função do uso agrícola do biossólido.

A identificação e quantificação de compostos orgânicos presentes em biossólidos auxilia na compreensão da dinâmica do C adicionado a solos via resíduos de modo geral (Reinertsen et al., 1984; Hattori \& Mukai, 1986; Janzen \& Kucey, 1988; Lerch et al., 1992). Diversas são as possibilidades de caracterização dos compostos orgânicos, porém no caso de biossólidos as informações acerca do tema são relativamente escassas na literatura. Dentre as abordagens investigativas clássicas utilizadas, pode-se destacar o fracionamento químico da matéria orgânica, segundo a solubilidade em solução ácida ou alcalina e as análises químicas aproximadas, estas últimas originalmente desenvolvidas para análises da qualidade de madeiras e forragens.

Usando uma seqüência de extrações baseadas em solubilidade Hattori \& Mukai (1986) analisaram o material orgânico presente em seis biossólidos provenientes de digestão anaeróbia, dois deles condicionados com cloreto férrico e cal hidratada, três com polímeros e um sem condicionamento.Os autores encontraram, independentemente do processo de condicionamento, teores de lipídeos, proteína crua e lignina predominando entre os compostos de $\mathrm{C}$ dos biossólidos. Os teores de açúcares solúveis e celulose foram extremamente baixos, variando de 2,2 a $3,8 \%$ e 0,2 a $5,0 \%$, respectivamente. Os teores de açúcares solúveis e os de proteína crua correlacionaram positivamente com as taxas de degradação dos resíduos incubados com solos (doses de 1 
e 5\%) por oito semanas, mas somente estes foram insuficientes para explicar as diferenças obtidas. As diferenças foram melhor explicadas por correlações negativas obtidas entre a soma de matéria inorgânica e lignina versus as taxas de decomposição do C dos resíduos. Os autores explicam que a matéria inorgânica e a lignina podem reduzir a decomposição de outros compostos orgânicos ligados a eles, como por exemplo a associação entre lignina e celulose, cuja ligação proporciona uma proteção física contra a degradação, à semelhança do que ocorre na parede celular de células vegetais. Em função dos resultados de caracterização do material orgânico dos biossólidos e avaliação da degradação após adição no solo, Hattori \& Mukai (1986) concluem que a dose de aplicação de biossólidos deve ser determinada levando-se em consideração também a qualidade do material orgânico dos resíduos.

Lerch et al. (1992), trabalhando com solo tratado com sete diferentes biossólidos (dose $10 \mathrm{t} \mathrm{ha}^{-1}$ ), também encontraram correlação positiva entre os teores de proteína nos resíduos a degradação do C orgânico após adição ao solo, destacando a provável predominância de proteínas bacterianas nos resíduos.

Piotrowski et al. (1984) compararam a composição orgânica de quatro biossólidos e dois compostos de lodo de esgoto, usando a técnica de $\mathrm{RMN}-{ }^{13} \mathrm{C}$ aplicada a amostras sólidas. Os autores observaram redução da intensidade das regiões relativas a compostos alifáticos de C e C-OH ou C-N (C alifático ligado a $\mathrm{OH}$ ou N) e aumento da intensidade da região referente a compostos aromáticos de C nas amostras de composto de lodo, ou seja, o tratamento adicional de compostagem dos lodos proporciona a formação de compostos aromáticos, característico de materiais em estágio mais avançado de humificação. Desse modo, menores taxas de decomposição podem ser esperadas no caso dos compostos de lodo em comparação aos biossólidos após aplicação ao solo.

Além da compreensão da dinâmica do C adicionado a solos via biossólidos, cuja composição orgânica parece ser relevante, outro aspecto carente de informações diz respeito às próprias medidas da mineralização do resíduo. A importância desse aspecto é traduzida pela presença do parâmetro na Norma Técnica P4.230 da CETESB (CETESB, 1999). A avaliação da degradabilidade de resíduos orgânicos de modo geral é feita a 
partir de incubações de laboratório com medições periódicas da quantidade de $\mathrm{CO}_{2}$ emanada. Ao final do período de incubação, normalmente 60 a 90 dias, obtêm-se a taxa de degradação do material. Nesses experimentos presume-se que a diferença entre a liberação de $\mathrm{CO}_{2}$ do solo incubado sozinho e do mesmo solo tratado com o resíduo é proveniente da degradação da fração orgânica adicionada, isto é, do C-orgânico introduzido com a dose do biossólido. Sabe-se no entanto que isso não é totalmente verdadeiro e que parte do $\mathrm{CO}_{2}$ evoluído do solo tratado é proveniente da degradação da matéria orgânica edáfica original (Terry et al., 1979a; Hsieh et al., 1981; Bernal et al., 1998a); é o chamado "priming effect" ou efeito priming. Dentre os escassos trabalhos que avaliaram diretamente o efeito priming em solos tratados com biossólidos, pode-se citar o de Terry et al. (1979a). Nesse estudo os autores trabalharam com lodo de esgoto sintético marcado com ${ }^{14} \mathrm{C}$ adicionado a um solo em dose correspondente $22 \mathrm{t} \mathrm{ha}^{-1}$, onde ao final de 336 dias de incubação concluíram que a adição do biossólido aumentou em 100\% a degradação da matéria orgânica original do solo. Desse modo, deve-se atentar para o fato de os métodos respirométricos estarem incorporando erros relativamente elevados, uma vez pressuposto que o efeito priming dever ser mínimo, cerca de $4 \%$ (Hsieh et al., 1981).

Em estudo de campo, o efeito priming pode ter sido o responsável pelos menores teores de $\mathrm{C}$ em um Latossolo Vermelho-Amarelo (camada 0-5 e 5-10 cm), de textura média, sob plantio de eucalipto e tratado com doses de 10, 20 e $40 \mathrm{t} \mathrm{ha}^{-1}$ aplicadas superficialmente e sem incorporação, em comparação ao tratamento fertilização mineral (Vaz \& Gonçalves, 2002). 


\subsection{Capacidade de troca catiônica de biossólidos e solos tratados}

Um dos parâmetros que melhor define a fertilidade do solo é sua capacidade de troca catiônica (CTC), derivada principalmente do teor e qualidade das argilas e da MOS (Glória, 1992). Regiões tropicais e subtropicais, com solos altamente intemperizados, exibem a CTC total fortemente dependente da MOS, sendo que a manutenção ou aumento dos teores de MOS são fundamentais na retenção dos nutrientes e na diminuição de perdas por lixiviação (Brady, 1989; Bayer \& Mielniczuk, 1999). Além disso, espécies químicas potencialmente tóxicas, como $\mathrm{Cd}^{+2}$ e $\mathrm{Zn}^{+2}$, podem ser imobilizadas no solo, reduzindo a absorção pelas plantas e prevenindo contra a contaminação de cursos d’água e águas subterrâneas (Melfi \& Montes, 2001).

O conteúdo orgânico de biossólidos deve incrementar a CTC de solos tratados (Melo \& Marques, 2000), embora a real contribuição dessa MO não seja clara nos estudos realizados. Em alguns estudos a CTC é calculada através da soma dos cátions trocáveis no solo (Roberts et al., 1988; Melo et al., 1994), enquanto que em outros, a CTC é determinada com o uso de um cátion índice a pH 7,0 (Simeoni et al., 1984) ou ao pH natural (Oliveira, 2000). A CTC calculada sofre o efeito das quantidades de cátions adicionadas via resíduo e por isso é comum que ocorra correlação significativa entre aumentos de C-orgânico e aumentos da CTC do solo tratado (Barreto, 1995; Oliveira et al., 2002), uma vez que doses crescentes de lodo tendem a incrementar tanto as concentrações de cátions, quanto de C-orgânico.

Oliveira (2000), utilizando método de determinação da CTC com um cátion índice, observou que o aumento da CTC foi melhor correlacionado com os incrementos no pH do que com alterações no conteúdo orgânico do solo. Essa observação também foi feita por Barreto (1995).

De acordo com o trabalho de Cavallaro et al. (1993) a CTC calculada pode sofrer aumento ou redução após aplicação de biossólidos, à depender do teor de $\mathrm{Al}$ original do solo tratado e concentrações de cátions no biossólido. Nesse estudo os autores usaram dois solos de Porto Rico (um com elevado teor de $\mathrm{Al}^{+3}$ e outro com cerca da metade do teor do primeiro) que receberam doses de 8, 16 e $24 \mathrm{t} \mathrm{ha}^{-1}$ de um biossólido. O aumento da CTC calculada foi atribuída as quantidades de Ca e Mg 
aplicadas via doses de biossólido ao solo que continha menor teor de $\mathrm{Al}^{+3}$, enquanto que o redução da CTC calculada foi creditada ao decréscimo de $\mathrm{Al}^{+3}$ não balanceado por similar aumento de $\mathrm{Ca}^{+2}$ no complexo de troca do solo que continha mais $\mathrm{Al}^{+3}$. Nesse último caso, a CTC também foi avaliada mediante a determinação com um cátion índice, mostrando aumentou do parâmetro com a dose de $24 \mathrm{t} \mathrm{ha}^{-1}$ de lodo, o que provavelmente ocorreu em função do incremento de carbono orgânico verificado, bem como pela liberação de cargas negativas, decorrentes da neutralização ou complexação do $\mathrm{Al}^{+3}$ do solo.

A contribuição de resíduos orgânicos na CTC de solos irá depender da natureza dos compostos orgânicos presentes (Rodella, 1996). Como biossólidos possuem uma diversidade de substâncias orgânicas, dentre elas substâncias apolares como óleos, graxas, resinas e ceras, se estas estiverem em concentrações elevadas, por serem insolúveis em água e não formarem carga, a contribuição para a CTC de solos deve ser pequena (Oliveira, 2000). Hohla et al. (1978) verificaram em um solo que recebeu aplicações sucessivas de lodo por 6 anos, num total de $298 \mathrm{t} \mathrm{ha}^{-1}$ (base seca), aumento do C-orgânico (camada 0-15 cm) de 9,5 para 22,9 $\mathrm{g} \mathrm{kg}^{-1}$. O solo tratado com lodo apresentou 10,9 \% do C-orgânico total presente em carboidratos e 11,9 \% em óleos e graxas, enquanto que no solo controle, o C presente em carboidratos foi 18,9 \% do Corgânico total, contra 1,7 \% presentes em óleos e graxas, o que sugeriu uma acumulação de substâncias apolares provocada pelas repetidas aplicações de lodo de esgoto ao solo.

Glória (1992) ressalta que resíduos orgânicos ricos em compostos simples como açúcar e amido são oxidados rapidamente no solo e a formação de húmus pode ser incipiente, não contribuindo com a CTC do solo. O mesmo autor vincula o aumento da CTC à velocidade de decomposição das substâncias orgânicas do resíduo e aos produtos finais formados, destacando que talvez seja desejável teores relativamente elevados de lignina e celulose, compostos que tendem a sofrer oxidação mais lenta, o que em última análise contribuiria para a formação de materiais mais persistentes e que poderiam afetar de maneira duradoura a CTC do solo. 


\subsection{Estoque de carbono em solos tratados com biossólidos e qualidade da matéria orgânica do solo}

O equilíbrio global do C na biosfera é função de três reservatórios principais: os oceanos (38.000 Pg), a atmosfera (750 Pg) e o sistema terrestre (6.050 Pg), sendo que o C em solos representa cerca de $3,3 \%$ do $C$ total no planeta, contra 1,2\% na biomassa vegetal e 1,7\% na atmosfera (Eswaran et al., 1993). Mudanças de uso do solo e aplicações de fertilizantes estão entre os fatores relacionados à agricultura que possuem maior influência nos níveis de $\mathrm{CO}_{2}$ atmosféricos e no efeito estufa (Ajwa \& Tabatabai, 1994). De acordo com as informações elaboradas pelo Painel Intergovernamental para Mudanças Climáticas (IPCC, 1997), em escala global, cerca de 30\% das emissões de gases do efeito estufa é atribuída às atividades agrícolas e mudança de uso da terra, sendo este valor igual a 50\% quando se considera somente países em desenvolvimento, geralmente localizados em regiões tropicais e subtropicais.

Práticas de manejo, como o cultivo mínimo ou semeadura direta, tem sido investigadas quanto a capacidade em capturar C atmosférico no solo, o chamado seqüestro de carbono, visando integração ao conjunto de medidas para mitigação do aumento global de $\mathrm{CO}_{2}$ atmosférico e efeito estufa. Outra prática relacionada ao manejo de solos e que pode ser interessante sob a ótica de seqüestro de C é o uso de resíduos orgânicos na agricultura (Jenkinsosn et al., 1991; Ajwa \& Tabatabai, 1994), porém pesquisas nessa linha são ainda incipientes. Adicionalmente, com desenvolvimento recente do conceito de qualidade do solo, a MOS é hoje reconhecida como o principal parâmetro indicador dessa qualidade, intimamente relacionada com o equilíbrio global da biosfera e efetivação de uma agricultura mais sustentável no (Doran \& Parkin, 1994; Warkentin, 1995; Blum, 1997; Karlen et al., 1997; Reeves, 1997; Karlen et al., 2001).

O status do C orgânico de solos é função do balanço entre entradas e saídas do elemento no sistema. Em ecossistemas naturais, como florestas e pradarias, o conteúdo de C orgânico encontra-se estável pelo equilíbrio entre as entradas e as saídas. O uso agrícola do solo rompe o equilíbrio inicial, sendo observada uma redução acentuada do teor de C quando métodos de preparo intenso do solo e sistemas de cultura com baixa adição de resíduos vegetais são utilizados (Bayer \& Mielniczuk, 1999). Tal 
comportamento tem sérias implicações na qualidade do solo, a ponto de se afirmar que a redução do teor de MOS ou C-orgânico é acompanhada pela degradação das propriedades físicas, químicas e biológicas do solo, o que compromete a produtividade agrícola e a sustentabilidade da produção no tempo (Johnston, 1986; Reeves, 1997; Bayer \& Mielniczuk, 1999; Von Lützow et al., 2002). Dentre as características do solo afetadas pela MOS pode-se destacar a disponibilidade de nutrientes para as culturas, a capacidade de troca catiônica (CTC), a complexação de elementos tóxicos, a agregação do solo e a atividade microbiana edáfica (Bayer \& Mielniczuk, 1999).

Os estoques de C em solos são calculados em função do teor de C-orgânico e da densidade do solo. Aplicações de biossólidos em áreas agrícolas podem tanto alterar os teores de C no solo (Melo et al., 1994; Silva, 1995; Marques, 1996; Oliveira et al., 2002; Rocha, 2002; Vaz \& Gonçalves, 2002) como a densidade do mesmo (Terry et al., 1979a; Metzger \& Yaron, 1987; Metzger et al., 1987; Jorge et al., 1991; Marciano, 1999).

Jorge et al. (1991) e Marciano (1999) observaram reduções da densidade do solo com a aplicação de biossólidos, sendo esta tendência decorrente do aumento do teor de C e também ao estímulo a atividade microbiana de bactérias e fungos (Metzger et al., 1987). A redução da densidade em solos tratados com o resíduo poderia sugerir menores estoques de $C$, se estes não fossem também função do teor de C.

Em termos de teor de C-orgânico após a aplicação de biossólidos a solos agrícolas, de modo geral, são reportados aumentos com a adição de doses do resíduo, podendo ser transitório (Melo et al., 1994; Silva, 1995; Marques, 1996) ou mais prolongado (Marques, 1996; Oliveira et al., 2002), a depender da dose aplicada e freqüência de reaplicação. $O$ simples aumento do teor de $C$ pode não significar benefícios ao sistema solo-planta (Oliveira et al., 2002), mas independentemente disso, o aumento influencia o estoque de C edáfico. Para uma real interpretação do significado das alterações dos teores de C de solos, em função da aplicação de biossólidos, há necessidade, dentre outros aspectos, da avaliação da qualidade da MOS. No trabalho de Hohla et al. (1978), os autores verificaram incrementos de C orgânico após aplicações de biossólidos a um solo, sendo estes incrementos correlacionados positivamente com 
teores de óleos e graxas, os quais não teriam influência na CTC do solo, mas seriam contabilizados se o interesse fosse o estoque de C do solo tratado.

Redução dos teores de C orgânicos foram observados por Vaz \& Gonçalves (2002), em trabalho de campo pioneiro com Eucalyptus grandis crescendo em solo tratado com biossólido aplicado superficialmente, na entrelinha de plantio e sem posterior incorporação. Aos 6 e 12 meses de crescimento, os autores observaram reduções nos teores de MOS (0-5 cm) em função da aplicação do resíduo, sendo estas reduções negativamente correlacionadas com as doses até $40 \mathrm{t} \mathrm{ha}^{-1}$. Em camadas mais profundas até $20 \mathrm{~cm}$ nenhuma diferença foi constatada em relação ao tratamento controle a adubação mineral. Na mesma área, porém aos 32 meses da aplicação do resíduo, Rocha (2002) não encontrou diferenças significativas entre os teores de C no solo 0-5 cm tratado com doses do biossólido e na mesma camada do tratamento adubação mineral. Para as camadas 5-10 e 10-20 cm houve aumento dos teores de C no solo que recebeu a maior dose do resíduo (40 $\mathrm{t} \mathrm{ha}^{-1}$ ), em comparação ao tratamento adubação mineral. Nesse experimento o biossólido foi aplicado em superfície, sem incorporação, diferente daqueles citados anteriormente, onde aumentos de C-orgânico foram observados. 


\section{COMPOSIÇÃO QUÍMICA DA MATÉRIA ORGÂNICA DE BIOSSÓLIDOS E RELAÇÃO COM A DEGRADAÇÃO APÓS APLICAÇÃO NO SOLO}

\section{Resumo}

O presente estudo teve como objetivo geral avaliar a degradação de biossólidos após aplicação no solo, relacionando com a composição química inicial da matéria orgânica (MO) dos resíduos. Foram utilizados cinco biossólidos provenientes de

diferentes sistemas de tratamento de esgotos e/ou condicionamento químico para desidratação e/ou etapa complementar visando melhor adequação ao uso agrícola: BAC - biossólido anaeróbio condicionado com cal e cloreto férrico e desidratado mecanicamente; BAP - biossólido anaeróbio condicionado com polímero sintético e desidratado mecanicamente; BAS - biossólido anaeróbio seco termicamente; BLP = biossólido proveniente de lagoas de estabilização, condicionado com polímero sintético e desidratado mecanicamente; e CL - composto de lodo de esgoto obtido por compostagem em pilhas aeradas após mistura do BLP com bagaço de cana-de-açúcar e restos de poda urbana. A caracterização química da MO dos resíduos foi feita por meio de determinações analíticas dos teores totais, orgânicos e inorgânicos de C, N e P; teores de carbono solúvel em água; frações do carbono orgânico em função de graus de oxidação; e teores de açúcares solúveis, proteína bruta (PB), lipídeos, hemicelulose, celulose, lignina, taninos e fenóis. A degradação dos biossólidos foi determinada em experimento com quantificação do $\mathrm{CO}_{2}$ emanado a partir de misturas de amostras de um Latossolo, incubadas (70 dias, no escuro, a temperatura de $28^{\circ} \mathrm{C}$ e umidade correspondente a $60 \%$ da C.C.) com dose dos biossólidos correspondente a $40 \mathrm{t} \mathrm{ha}^{-1}$. Os resultados evidenciaram que os teores totais de $\mathrm{C}, \mathrm{N}$ e $\mathrm{P}$ variaram entre os biossólidos, com predominância do C (> 70\%) e do N (> 80\%) em compostos orgânicos. 
A distribuição do $\mathrm{P}$ entre compostos orgânicos e inorgânicos foi função do tratamento nas estações de tratamento de esgotos, ocorrendo predominância do P em compostos inorgânicos nos biossólidos BAC, BLP e CL, e do P em compostos orgânicos no BAS. O BAP apresentou cerca de $50 \%$ do total de P em cada compartimento. A MO do BLP e do CL mostrou-se mais estabilizada biologicamente, função do processo de tratamento na ETE, com taxas de degradação iguais a 7,16 e 5,38 \%, respectivamente, contra a média de 21,63 \% dos biossólidos digeridos anaeróbios (BAC, BAP e BAS). Em todos os biossólidos houve expressiva participação do compartimento protéico como constituinte da MO, apresentando valores médios entre 25 e $46 \%$ do total de MO. A proteína bruta, expressa como porcentagem do conteúdo orgânico dos resíduos, foi o parâmetro que melhor correlacionou com a taxa de degradação dos biossólidos ao final de 70 dias de incubação ( $\mathrm{r}=0,999$ e Prob. $>\mathrm{t}$ inferior a $10^{-4}$ ), sendo promissora sua utilização no sentido de previsão da degradação da MO de biossólidos após aplicação no solo. A participação do compartimento protéico foi crescente com o tempo de incubação, indicando que no início do período de avaliação outros compostos de orgânicos mais lábeis funcionaram como fonte de C e de energia para a microbiota edáfica.

\section{CHEMICAL COMPOSITION OF BIOSOLID ORGANIC MATTER AND RELATIONSHIP WITH DEGRADATION AFTER SOIL APPLICATION}

\section{Summary}

The aim of this study was to evaluate biosolid degradation after soil application, in relation to the initial chemical composition of the residue organic matter (OM). Five biosolids from different waste systems and/or different chemical conditioning to dehydration and/or complementary phase to adequate the residue for agricultural use were used: BAC - anaerobic biosolid conditioned with lime and ferric chloride and mechanically dehydrated; BAP - anaerobic biosolid conditioned with synthetic polymers mechanically dehydrated; BLP - biosolid originated in stabilization ponds and conditioned with synthetic polymers mechanically dehydrated; CL - sewage sludge 
compost originated from aerated pile composting of a mixture of BLP, crushed sugar cane and remains of urban pruning. Chemical composition of residue organic matter was characterized by $\mathrm{C}, \mathrm{N}$ and $\mathrm{P}$ total (organic and inorganic compounds); water soluble carbon; organic carbon fractions in function of oxidation levels; and soluble sugar, crude protein (PB), hemicellulose, cellulose, lignin, tannin and phenols concentrations. Biosolid degradation was determinated in a experiment done to quantify $\mathrm{CO}_{2}$ emitted from incubated Oxisol samples (70 days, in darkness, temperature of $28^{0} \mathrm{C}$ and humidity correspondent to $60 \%$ water holding capacity) with biosolid in a dose correspondent to $40 \mathrm{t} \mathrm{ha}^{-1}$. The results evinced that total $\mathrm{C}, \mathrm{N}$ and $\mathrm{P}$ were variable in the biosolids, with $\mathrm{C}$ (> 70\%) and $\mathrm{N}(>80 \%)$ predominance in organic compounds. P distribution in organic and inorganic compounds was as a function of the treatment used in the Plants, occurring predominance of $\mathrm{P}$ in inorganic compounds for BAC, BLP and CL biosolids and $\mathrm{P}$ in organic compounds for BAS. The BAP presented around $50 \%$ of total $\mathrm{P}$ in each fraction. BLP and CL organic matter showed higher biological stability, as a function of the treatment processes, with degradation rates of 7.16 and 5.38\%, respectively, against the average $21.63 \%$ of the anaerobic digested biosolids (BAC, BAP and BAS). All biosolids showed an expressive participation of protein pool as an organic matter constituent, with mean values between 25 and $46 \%$ of total organic matter. Crude protein, expressed as residue organic content percentage, was the parameter that better correlated with biosolid degradation rate at the end of 70 days of incubation $(r=0.999$ e Prob. $>\mathrm{t}$ lower than $10^{-4}$ ), being promising its utilization to preview biosolid organic matter degradation after addition to soils. Protein pool participation increased with incubation time, indicating that in the beginning on experiment more labile organic compounds worked as $\mathrm{C}$ and energy sources for the edafic microbiota. 


\subsection{Introdução}

O uso agrícola de biossólidos tem sido recomendado como prática agrícola para a manutenção da matéria orgânica (MO) do solo, recuperação de áreas degradadas e suprimento de nutrientes as plantas (Boyle \& Paul, 1989; Iakimenko et al., 1996; Bernal et al., 1998a). Programas visando a reciclagem agrícola desse resíduo devem não somente resolver o problema de disposição final do material, mas também prevenir contra efeitos adversos no ambiente, prezando pela conservação dos recursos naturais (Hsieh et al., 1981) e por benefícios agronômicos (Hernández et al., 1990). Nesse sentido, a dinâmica da MO de biossólidos após aplicação no solo merece especial atenção, uma vez que interfere no ciclo do carbono (C) do solo (Boyd et al., 1980; Gilmour et al., 1996b), na disponibilidade de nutrientes (Ayuso et al., 1992; FrancoHernández et al., 2003) e elementos potencialmente tóxicos (Bertoncini, 2002; Pires, 2003).

A degradação de resíduos orgânicos em geral, após aplicação no solo, é influenciada por fatores relacionados ao resíduo, ao solo e ao clima (Ajwa \& Tabatabai, 1994). Para biossólidos têm-se verificado que as características do resíduo, bem como as condições de temperatura e umidade, são mais determinantes da taxa de degradação, do que o tipo de solo (Tester et al., 1977; Sommers et al., 1979). Algumas características

dos biossólidos, reconhecidamente importantes no estabelecimento da taxa de degradação são: pH, conteúdo de nutrientes, teor de carbono (C), concentração de sais solúveis, teores de metais pesados e composição química da fração orgânica (Hattori \& Mukai, 1986). Valores excessivamente elevados de pH (Franco-Hernandéz et al., 2003; Santos et al., 2003), teores de metais pesados (Iakimenko et al., 1996) e sais solúveis (Tester \& Parr, 1983) conduzem a menores taxas de degradação dos resíduos. O teor de carbono do resíduo, embora apresente correlação positiva com a quantidade total de $\mathrm{CO}_{2}$ emanada a partir da misturas de amostras de solo e biossólidos (Pires et al., 2002; Santos et al., 2002), pode correlacionar inversamente com a taxa de degradação (Santos et al., 2002). Isso ocorre porque o material orgânico adicionado ao solo contém uma ampla gama de compostos de carbono (carboidratos, lipídios, aminoácidos, lignina, etc.), que variam em sua taxa de degradação individual, sendo a decomposição do resíduo 
dependente do conteúdo relativo entre eles (Reddy et al., 1980; Marstorp, 1996; Bernal et al., 1998a). Desse modo, a avaliação da qualidade da MO de biossólidos pode auxiliar na previsão da taxa de degradação do desses resíduos e na compreensão da dinâmica do carbono em solos tratados.

Algumas publicações têm abordado a caracterização da fração orgânica de biossólidos, em especial das substâncias húmicas extraídas por meio de procedimentos de fracionamento químico (Boyd et al., 1980; Deiana et al., 1990; Hernández et al., 1990; Canellas et al., 2000; Bertoncini, 2002). Entretanto, pouco se conhece acerca da relação entre as características da MO dos biossólidos e as taxas de degradação após aplicação no solo. A taxa de degradação de resíduos orgânicos em geral têm sido determinada sob condições controladas de temperatura e umidade, em que amostras de solo e resíduo, e somente solo (controle), são incubados por períodos variáveis de 60 a 90 dias, medindo-se periodicamente a quantidade de carbono emanada na forma de $\mathrm{CO}_{2}$ $\left(\mathrm{C}-\mathrm{CO}_{2}\right)$. A diferença de $\mathrm{C}-\mathrm{CO}_{2}$ emanada da mistura de solo e resíduo, e do controle, é atribuída a degradação dos compostos orgânicos presentes no material aplicado e com esse valor calcula-se a taxa de degradação em relação a quantidade de carbono adicionada inicialmente. Esses experimentos, denominados respirométricos, são de longa duração e custos relativamente elevados. Considerando que a qualidade da MO de biossólidos é determinante na taxa de degradação do carbono adicionado ao solo (Hattori \& Mukai, 1986), pode-se pensar na quantificação e uso de alguns compostos orgânicos, ou índices calculados a partir destes, para previsão da degradação de biossólidos no solo, reduzindo custos, facilitando o acesso a informação e conseqüentemente ao uso agrícola do resíduo. A Norma Técnica P4.230 da CETESB (CETESB, 1999), que regula o uso agrícola de biossólidos no Estado de São Paulo, exige um mínimo de 30 \% de degradação, num período de 62 dias de incubação, para biossólidos provenientes do tratamento esgotos industriais ou mistos de esgotos industriais e domiciliares. A aplicabilidade de tal valor também deve ser revista, considerando-se, dentre outros fatores, a qualidade do material orgânico do resíduo e os benefícios agronômicos esperados. Biossólidos compostados podem conter pequena quantidade de compostos facilmente degradáveis, predominando compostos orgânicos 
parcialmente estabilizados (Castellanos \& Pratt, 1981), o que conduz a modestas taxas de degradação no solo (Bernal et al., 1998a) e menor disponibilização de nutrientes (Castellanos \& Pratt, 1981; Riffaldi et al., 1988), concomitante a aumentos no estoque de carbono e a benefícios como melhoria na retenção de água e capacidade de troca catiônica, função da natureza dos compostos orgânicos do resíduo.

O objetivo geral do presente estudo foi avaliar a degradação de biossólidos após aplicação no solo, relacionando com a composição química inicial da MO dos resíduos e com os processos para geração dos mesmos nas estações de tratamento de esgotos (ETEs). Foram objetivos específicos: (i) caracterizar quimicamente a MO dos biossólidos; (ii) identificar diferentes fases durante o processo de degradação da MO adicionada ao solo, usando para isso o ajuste dos dados de $\mathrm{C}-\mathrm{CO}_{2}$ emanado a modelos de cinética química de primeira ordem; (iii) testar um método de fracionamento químico do carbono orgânico dos biossólidos, originalmente desenvolvido para amostras de solo; e (iv) identificar parâmetros promissores para previsão da taxa de degradação de biossólidos após aplicação ao solo.

\subsection{Material e Métodos}

\subsubsection{Solo}

O solo utilizado foi um LATOSSOLO VERMELHO Eutroférrico de textura argilosa, coletado de área sob cultivo de cana-de-açúcar, no município de Santa Bárbara d'Oeste, SP. Todo volume coletado foi seco ao ar, peneirado em malha 2 mm (TFSA), homogeneizado e reservado para as incubações. Algumas características químicas do solo para fins de fertilidade, determinadas conforme descrito em Raij \& Quaggio (1983), foram: $\mathrm{pH}=5,2 ; \mathrm{MO}=28 \mathrm{~g} \mathrm{dm}^{-3} ; \mathrm{K}=0,6 \mathrm{mmol}_{\mathrm{C}} \mathrm{dm}^{-3} ; \mathrm{Ca}=6 \mathrm{mmol}_{\mathrm{C}} \mathrm{dm}^{-3} ; \mathrm{Mg}=$ $2 \mathrm{mmol}_{\mathrm{C}} \mathrm{dm}^{-3} ; \mathrm{Al}=6 \mathrm{mmol}_{\mathrm{c}} \mathrm{dm}^{-3} ; \mathrm{H}+\mathrm{Al}=14 \mathrm{mmol}_{\mathrm{c}} \mathrm{dm}^{-3} ; \mathrm{SB}=8,6 \mathrm{mmol}_{\mathrm{C}} \mathrm{dm}^{-3}$; CTC $=22,6 \mathrm{mmol}_{\mathrm{c}} \mathrm{dm}^{-3} ; \mathrm{V}=38 \%$; e $\mathrm{m}=41 \%$. 


\subsubsection{Biossólidos}

Foram utilizados cinco resíduos, sendo quatro biossólidos e um composto de lodo de esgoto, designados a partir daqui, todos, simplesmente como biossólidos. A escolha dos resíduos ocorreu em função das diferenças entre os sistemas de tratamento dos esgotos nas estações de tratamento (ETEs) e/ou processos de condicionamento químico para desidratação dos biossólidos e/ou ainda etapa complementar visando melhor adequação dos resíduos ao uso agrícola (Tabela 3).

Tabela 3. Biossólidos utilizados no experimento: sistema de tratamento dos esgotos nas estações, condicionamento químico para desidratação e etapa complementar para melhor adequação ao uso agrícola

\begin{tabular}{|c|c|c|c|}
\hline Biossólido & Tratamento dos esgotos & Condicionamento químico & Etapa complementar \\
\hline BAC & $\begin{array}{c}\text { Lodos ativados; reator } \\
\text { anaeróbio }\end{array}$ & Cal hidratada e cloreto férrico & Desidratação mecânica \\
\hline BAP & $\begin{array}{l}\text { Lodos ativados; reator } \\
\text { anaeróbio }\end{array}$ & Polímero sintético & Desidratação mecânica \\
\hline BAS & $\begin{array}{c}\text { Lodos ativados; reator } \\
\text { anaeróbio }\end{array}$ & Polímero sintético & $\begin{array}{l}\text { Secagem térmica, sem } \\
\text { superaquecimento dos } \\
\text { grânulos de lodo } \\
\text { (70 minutos) }\end{array}$ \\
\hline BLP & $\begin{array}{l}\text { Lagoas aeradas, seguidas } \\
\text { de lagoas de decantação } \\
\text { (idade média } 1 \text { ano) }\end{array}$ & Polímero sintético & $\begin{array}{l}\text { Secagem em leitos com } \\
\text { revolvimento periódico } \\
\text { (120 dias) }\end{array}$ \\
\hline CL & $\begin{array}{l}\text { Lagoas aeradas, seguidas } \\
\text { de lagoas de decantação } \\
\text { (idade média } 1 \text { ano) }\end{array}$ & Polímero sintético & $\begin{array}{l}\text { Compostagem com bagaço de } \\
\text { cana e restos de poda urbana } \\
\text { (90 dias) }\end{array}$ \\
\hline
\end{tabular}

Três dos biossólidos, provenientes de sistema de lodos ativados com reator anaeróbio, condicionados com cal hidratada e cloreto férrico (BAC), ou polímero sintético (BAP), ou seco termicamente (BAS), foram obtidos junto a Companhia de Saneamento Básico do Estado de São Paulo - SABESP, ETE de Barueri, que trata dos esgotos de parte da grande São Paulo, constituído de mistura de esgotos domiciliares e industriais. O biossólido gerado em sistema de tratamento de esgoto domiciliar, por 
meio de lagoas aeradas de mistura completa, seguidas de lagoas de decantação, e condicionado com polímero sintético (BLP) foi cedido pela Companhia de Saneamento de Jundiaí, que gerencia a ETE do município de Jundiaí, SP. O composto de lodo (CL) também é proveniente da ETE de Jundiaí e foi compostado por 90 dias, utilizando o processo de pilhas aeradas, em mistura do BLP com bagaço de cana-de-açúcar e restos de poda urbana, na razão volumétrica de $1: 1: 0,33$; respectivamente.

Algumas características químicas dos biossólidos, determinadas segundo recomendado em Eaton et al. (1995), são apresentadas na Tabela 4.

Tabela 4. Caracterização química parcial dos biossólidos utilizados no estudo

\begin{tabular}{|c|c|c|c|c|c|c|}
\hline \multirow[t]{2}{*}{ Parâmetro } & \multirow[t]{2}{*}{ Unidade } & \multicolumn{5}{|c|}{ Biossólidos $^{\text {a }}$} \\
\hline & & $B A C$ & BAP & BAS & $B L P$ & $C L$ \\
\hline Umidade & $\mathrm{g} \mathrm{kg}^{-1}$ & 539,5 & 723,0 & 20,0 & 583,3 & 426,0 \\
\hline pH água (1:5) & ------ & 11,8 & 6,5 & 7,0 & 4,8 & 6,0 \\
\hline C.E. (1:5) & $\mathrm{mS} \mathrm{cm}^{-1}$ & 5,60 & 3,58 & 3,05 & 2,43 & 3,64 \\
\hline C-total & $\mathrm{g} \mathrm{kg}^{-1}$ & 157,63 & 298,15 & 333,89 & 289,10 & 294,35 \\
\hline N-total & $\mathrm{g} \mathrm{kg}^{-1}$ & 15,83 & 28,85 & 39,64 & 22,88 & 18,0 \\
\hline $\mathrm{C} / \mathrm{N}$ & ------ & 9,97 & 10,33 & 8,42 & 12,63 & 16,35 \\
\hline P-total & $\mathrm{g} \mathrm{kg}^{-1}$ & 7,62 & 17,96 & 17,01 & 5,50 & 3,80 \\
\hline K-total & $\mathrm{g} \mathrm{kg}^{-1}$ & 0,93 & 2,41 & 1,88 & 2,74 & 0,002 \\
\hline Ca-total & $\mathrm{g} \mathrm{kg}^{-1}$ & 257,65 & 22,256 & 32,67 & 10,33 & 6,58 \\
\hline
\end{tabular}

Os teores dos metais pesados $\mathrm{Cd}, \mathrm{Cr}, \mathrm{Cu}$, $\mathrm{Ni}$ e $\mathrm{Zn}$ também foram quantificados (dados não apresentados) e estiveram dentro da faixa permitida pela Norma P4.230 (CETESB, 1999), da Companhia de Tecnologia de Saneamento Ambiental - CETESB, que regula o uso de biossólidos em áreas agrícolas no Estado de São Paulo. 


\subsubsection{Caracterização química da matéria orgânica dos biossólidos}

A caracterização química da MO dos biossólidos foi realizada por meio de determinações analíticas dos teores totais de $\mathrm{C}, \mathrm{N}$ e $\mathrm{P}$, e dos mesmos presentes em compostos orgânicos (C-orgânico, N-orgânico e P-orgânico) e em compostos inorgânicos (C-inorgânico, N-inorgânico e P-inorgânico); teores totais de matéria orgânica (MO-total) e carbono solúvel em água (C-solúvel); fracionamento químico do carbono em função de diferentes graus de oxidação; e teores de alguns compostos orgânicos de interesse: açúcares solúveis, proteína bruta, lipídeos (extrato etéreo compostos por óleos e graxas), hemicelulose, celulose, lignina, fenóis totais e taninos totais. Na seqüência são apresentados os métodos e cálculos utilizados:

- MO-total: determinada por método gravimétrico baseado na perda de massa da amostra após queima a $550{ }^{\circ} \mathrm{C}$, durante 2 horas.

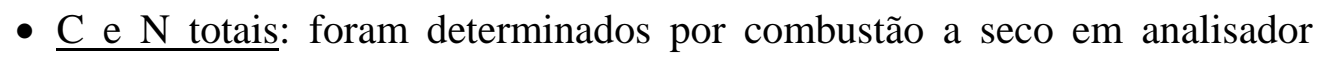
LECO CN-2000, usando amostras dos biossólidos moídas e peneiradas a 60 meshes;

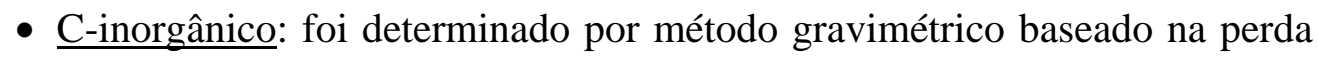
de massa em função da liberação de $\mathrm{CO}_{2}$ após tratamento da amostra com solução ácida diluída, quantificando-se o carbono presente em carbonatos (Loeppert \& Suarez, 1996);

- C-orgânico: diferença entre o C-inorgânico e o C-total;

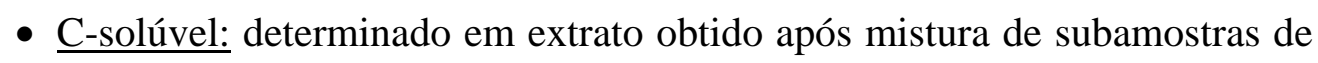
cada biossólido e água deionizada, na razão de 1:5, respectivamente, agitação durante duas horas e posterior filtragem. A determinação analítica do carbono solúvel foi feita por meio de oxidação com $\mathrm{K}_{2} \mathrm{Cr}_{2} \mathrm{O}_{7}$, em meio ácido (Eaton et al., 1995). 
- $\mathrm{N}$-inorgânico: foi determinado por titulação do extrato de análise com solução ácida padronizada, após procedimento de extração com solução de $\mathrm{KCl} 2 \mathrm{~mol} \mathrm{~L}^{-1}$, destilação em meio alcalino e recebimento em solução de ácido bórico e mistura de indicadores (Mulvaney, 1996);

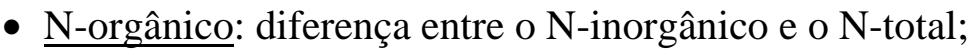

- P-total e P-inorgânico: foi utilizado o método desenvolvido por Sounders \& William (1955), modificado por Walker \& Adams (1958). O P-inorgânico foi determinado por leitura da absorbância do extrato para análise, obtido a partir de extração da amostra íntegra (apenas peneirada e/ou moída) com $\mathrm{H}_{2} \mathrm{SO}_{4}$ 0,5 mol L-1 . O P-total foi também determinado por meio da leitura da absorbância do extrato, seguindo o mesmo procedimento de extração, porém a amostra utilizada foi previamente queimada a $550^{\circ} \mathrm{C}$ durante 1 hora;

- P-orgânico: diferença entre o P-inorgânico e o P-total;

- Fracionamento do C-orgânico por graus de oxidação: foi adaptado de Chan et al. (2001), cujo fundamento se baseia na oxidação do C-orgânico das amostras por combustão seca e também úmida $\left(\mathrm{K}_{2} \mathrm{Cr}_{2} \mathrm{O}_{7}\right)$ em meio ácido, neste último caso com duas concentrações de $\mathrm{H}_{2} \mathrm{SO}_{4}, 12$ e $6 \mathrm{~mol} \mathrm{~L}^{-1}$. O procedimento adotado permitiu a obtenção de três frações de C-orgânico:

- C-lábil (6 $\mathrm{mol} \mathrm{L}^{-1} \mathrm{H}_{2} \mathrm{SO}_{4}$ ): C-orgânico oxidado por $\mathrm{K}_{2} \mathrm{Cr}_{2} \mathrm{O}_{7}$ em meio ácido de 6 mol L ${ }^{-1}$ de $\mathrm{H}_{2} \mathrm{SO}_{4}$;

- C-médio (12 - $6 \mathrm{~mol} \mathrm{~L}^{-1} \mathrm{H}_{2} \mathrm{SO}_{4}$ ): diferença entre o C-orgânico oxidado por $\mathrm{K}_{2} \mathrm{Cr}_{2} \mathrm{O}_{7}$ em meio ácido, com 12 e $6 \mathrm{~mol} \mathrm{~L}^{-1}$ de $\mathrm{H}_{2} \mathrm{SO}_{4}$; e

- C-resistente (C-total - $12 \mathrm{~mol} \mathrm{~L}^{-1} \mathrm{H}_{2} \mathrm{SO}_{4}$ ): C-orgânico residual obtido pela diferença entre a oxidação com $\mathrm{K}_{2} \mathrm{Cr}_{2} \mathrm{O}_{7}$ em meio ácido de $12 \mathrm{~mol} \mathrm{~L}^{-1}$ de $\mathrm{H}_{2} \mathrm{SO}_{4}$, e o total de C-orgânico (C-total - C-inorgãnico). 
- Compostos orgânicos: foram determinados por meio de seqüências complexas de digestões e extrações, originalmente desenvolvidas para análises de forrageiras e madeira. Os teores de lipídeos (extrato etéreo) e proteína bruta (PB) foram determinados conforme recomendação da Association of Official Analytical Chemists (1995), enquanto os carboidratos, a celulose, a hemicelulose, a lignina, os taninos e os fenóis foram quantificados conforme descrito em Van Soest \& Wine (1967).

\subsubsection{Experimento para avaliação da degradação dos biossólidos}

Amostras de $300 \mathrm{~g}$ de TFSA foram incubadas com os biossólidos, em potes de vidro $(1,5 \mathrm{~L})$, durante um período de 70 dias, no escuro, à temperatura de $28 \pm 1{ }^{\circ} \mathrm{C}$ e umidade correspondente a $60 \%$ da capacidade de campo das misturas. O preparo das amostras dos biossólidos para uso no experimento consistiu em secagem a $40^{\circ} \mathrm{C}$ e posterior moagem, passando em peneira de malha $0,84 \mathrm{~mm}$.

Os tratamentos testados foram em número de oito, além do controle (somente TFSA), com três repetições cada, num total de 27 unidades experimentais, dispostas inteiramente ao acaso para incubação. A dose referência escolhida para comparação dos cinco biossólidos foi o equivalente a $40 \mathrm{t} \mathrm{ha}^{-1}$ (base seca) e, somente para o BAP, foram testadas também doses equivalentes a 10, 20 e 80 t ha $^{-1}$ (base seca).

A avaliação da degradação dos biossólidos após mistura com o solo foi feita por meio de experimento respirométrico, com avaliação do $\mathrm{CO}_{2}$ emanado. Seguiu-se o método recomendado pela Companhia de Tecnologia de Saneamento Ambiental - CETESB, Norma Técnica P4.230 (CETESB, 1999), com captura do $\mathrm{CO}_{2}$ emanado, usando solução padronizada de $\mathrm{NaOH} \mathrm{0,5} \mathrm{mol} \mathrm{L}^{-1}$. Houve troca periódica da solução de $\mathrm{NaOH}$ contida no interior dos potes, encaminhando imediatamente aquelas retiradas para quantificação do $\mathrm{CO}_{2}$ por meio de leitura da condutividade elétrica (Rodella \& Saboya, 1999). 


\subsubsection{Forma de análise dos resultados}

Os resultados da caracterização química da MO dos biossólidos foram comparados por meio dos valores médios de cada variável e respectivo desvio padrão. A discussão desses dados objetivou relacionar as diferenças de composição química da MO dos biossólidos, com os processos de obtenção e processamento dos mesmos nas ETEs.

Os dados de $\mathrm{C}-\mathrm{CO}_{2}$ emanado foram interpretados em termos de $\mathrm{C}-\mathrm{CO}_{2}$ emanado acumulado, descontado a testemunha, sendo o resultado dessa subtração atribuída à degradação do carbono orgânico do resíduo (C-degradado). Tais valores foram ajustados a equações de cinética química de primeira ordem, com uma fase (monofásica), duas fases (bifásica) e três fases (trifásica), de modo a evidenciar diferenças na qualidade da fração orgânica dos resíduos, bem como, considerando um determinado biossólido, avaliar a existência de classes de compostos orgânicos com diferentes graus de biodegradabilidade no solo. Na seqüência são apresentadas as equações de cinética química utilizadas. 


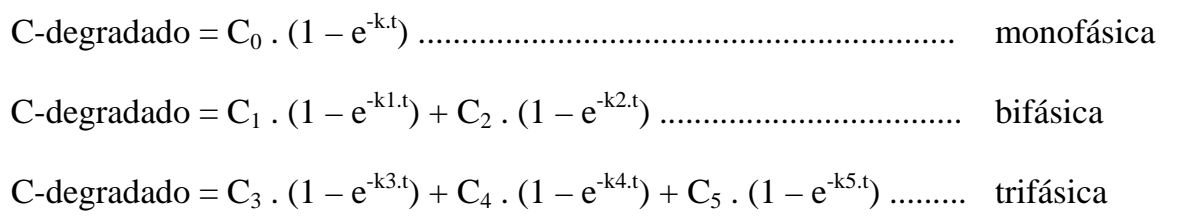

Em que:

$\mathrm{C}$-degradado $=$ quantidade de carbono $\left(\mathrm{mg} \mathrm{kg}^{-1}\right)$ emanada na forma de $\mathrm{CO}_{2}$ no tempo $\mathrm{t} ;(1,2$ e 3)

$\mathrm{C}_{0}=$ carbono $\left(\mathrm{mg} \mathrm{kg}^{-1}\right)$ potencialmente mineralizável em 70 dias de incubação; (1)

k = constante de velocidade da reação de degradação do carbono orgânico do biossólido (dia ${ }^{-1}$ ); (1)

$\mathrm{t}$ = tempo de incubação em dias; (1, 2 e 3)

$\mathrm{C}_{1}=$ carbono $\left(\mathrm{mg} \mathrm{kg}^{-1}\right)$ potencialmente mineralizável durante a primeira fase de degradação do carbono orgânico do biossólido; (2)

$\mathrm{k}_{1}=$ constante de velocidade da reação de degradação do carbono orgânico do biossólido durante a primeira fase de degradação $\left(\operatorname{dia}^{-1}\right)$; (2)

$\mathrm{C}_{2}=$ carbono $\left(\mathrm{mg} \mathrm{kg}^{-1}\right)$ potencialmente mineralizável durante a segunda fase de degradação do carbono orgânico do biossólido; (2)

$\mathrm{k}_{2}=$ constante de velocidade da reação de degradação do carbono orgânico do biossólido durante a segunda fase de degradação $\left(\operatorname{dia}^{-1}\right)$; (2)

$\mathrm{C}_{3}=$ carbono $\left(\mathrm{mg} \mathrm{kg}^{-1}\right)$ potencialmente mineralizável durante a primeira fase de degradação do carbono orgânico do biossólido; (3)

$\mathrm{k}_{3}$ = constante de velocidade da reação de degradação do carbono orgânico do biossólido durante a primeira fase de degradação ( dia $\left.^{-1}\right)$; (3)

$\mathrm{C}_{4}=$ carbono $\left(\mathrm{mg} \mathrm{kg}^{-1}\right)$ potencialmente mineralizável durante a segunda fase de degradação do carbono orgânico do biossólido; (3)

$\mathrm{k}_{4}=$ constante de velocidade da reação de degradação do carbono orgânico do biossólido durante a segunda fase de degradação ( dia $\left.^{-1}\right)$; (3)

$\mathrm{C}_{5}=$ carbono $\left(\mathrm{mg} \mathrm{kg}^{-1}\right)$ potencialmente mineralizável durante a terceira fase de degradação do carbono orgânico do biossólido; (3)

$\mathrm{k}_{5}=$ constante de velocidade da reação de degradação do carbono orgânico do biossólido durante a terceira fase de degradação $\left(\mathrm{dia}^{-1}\right)$; (3) 
As taxas de degradação dos biossólidos determinadas no final do período de incubação foram correlacionadas com os resultados da caracterização química da MO. Os parâmetros de caracterização foram expressos em relação a massa seca e em relação ao total de MO ou C-orgânico dos resíduos. Alguns índices utilizados comumente como preditores da degradação de materiais orgânicos de origem vegetal, foram testados para os biossólidos: relação C-orgânico/N (C/N), relação Lignina/N, Índice Lignocelulósico $\left(\mathrm{ILC}^{1}\right)$ e Quociente Holocelulose : Lignocelulose $\left(\mathrm{QHL}^{2}\right)$. Outros quatro índices tentativos foram testados, assumindo que frações de carbono separadas em função de diferentes graus de oxidação poderiam, em curto período de avaliação (70 dias), melhor representar o carbono efetivamente metabolizado pelos microrganismos do solo. Esses índices foram: Razão de Carbono Oxidável $\left(\mathrm{RCO}^{3}\right)$, relação C-lábil/N, C-médio/N, C-resistente/N.

A relação entre qualidade da MO dos biossólidos e a cinética de degradação também foi investigada. Utilizou-se para isso, correlações estatísticas dos teores dos compostos orgânicos (expressos em relação ao total de MO) e carbono nas frações lábil, média e resistente (expressos em relação ao total de C-orgânico), com os valores de $\mathrm{k}_{1} \mathrm{e}$ $k_{2}$, que são indicativo da velocidade da reação de degradação do C-orgânico dos biossólidos no solo, respectivamente para a primeira e segunda fase do processo. Tal procedimento também permitiu inferir acerca da validade de adoção do fracionamento do carbono orgânico em biossólidos, considerando que o método adotado é puramente químico (graus diferenciados de oxidação) e que foi utilizado por Chan et al. (2001) em amostras de solo.

Foram feitas correlações simples entre todas as variáveis determinadas ou calculadas para auxiliar na discussão dos resultados (Apêndices 1 e 2).

Todas as correlações foram realizadas utilizando-se os valores médios.

\footnotetext{
${ }^{1}$ ILC = lignina / (lignina + celulose);

${ }^{2} \mathrm{QHL}=$ (hemicelulose + celulose) $/$ (hemicelulose + celulose + lignina);

${ }^{3} \mathrm{RCO}=$ razão entre C-total e C determinado pelo método Walkley-Black.
} 


\subsection{Resultados e discussão}

\subsubsection{Caracterização química da matéria orgânica dos biossólidos}

\subsubsection{Carbono, nitrogênio e fósforo}

Os teores totais de C, N e P nos biossólidos variaram entre 185,93 e 345,70 $\mathrm{g} \mathrm{kg}^{-1}, 17,40$ e $42,63 \mathrm{~g} \mathrm{~kg}^{-1}$, e 3,80 e 17,96 $\mathrm{g} \mathrm{kg}^{-1}$, respectivamente (Tabela 5). Entretanto, a distribuição do total do $\mathrm{C}$ e do $\mathrm{N}$ em compostos orgânicos e inorgânicos revelou que a fração predominante do C (> 70\%) e do N (> 80\%) encontra-se no compartimento orgânico. O teor de C-inorgânico no BAC, $50 \mathrm{~g} \mathrm{~kg}^{-1}$, cerca de cinco vezes superior ao determinado nos biossólidos BAP e BAS, é função do condicionamento químico usando cal hidratada, que propicia a formação de carbonato, provavelmente precipitado como carbonato de cálcio ao valor de $\mathrm{pH}$ do resíduo, igual a 11,8 (Tabela 4). No caso do P, os biossólidos BAC, BLP e CL apresentaram maior proporção de $\mathrm{P}$ em compostos inorgânicos, em relação à presença em compostos orgânicos, ocorrendo o contrário no caso do BAS, cujo teor médio de P-orgânico foi o correspondente a 76\% do total. O biossólido BAP apresentou teores semelhantes de Porgânico e P-inorgânico. Biossólidos podem conter, em função do tratamento recebido nas ETEs, predominância de formas inorgânicas de P (Sommers et al., 1976) ou formas orgânicas de P (Chae \& Tabatabai, 1981). No trabalho de Sommers et al. (1976), os biossólidos provenientes de sistema de lodos ativados exibiram teores de P-inorgânico entre 64 a $82 \%$ do total de P.

De modo geral, pela análise da Tabela 5, nota-se que os diferentes sistemas de obtenção dos biossólidos têm influência, não somente nos teores totais dos elementos C, N e P, mas também na partição entre a presença dos mesmos em compostos orgânicos e inorgânicos. Tais aspectos tornam-se importantes ao considerar o uso agrícola desses resíduos, em especial quando o objetivo é fornecer N (CETESB, 1999) e P as plantas (Ayuso et al., 1992; James \& Aschmann, 1992; Rydin \& Otabbong, 1997). Franco-Hernández et al. (2003) estudaram o efeito do uso de cal hidratada, irradiação com ${ }^{60} \mathrm{Co}$ e pasteurização na redução de patógenos de um biossólido, verificando também alterações na composição química do material. Os autores observaram reduções dos teores C-orgânico, P-total e N-inorgânico, e aumento do teor de C-inorgânico, 
quando o biossólido recebeu cal hidratada, semelhante ao apresentado na Tabela 5, entretanto, não foi verificado, no primeiro caso, alteração do teor de N-total.

Tabela 5. Teores totais de $\mathrm{C}, \mathrm{N}$ e $\mathrm{P}$ nos biossólidos e teores desses elementos em compostos orgânicos (C-org., N-org. e P-org.) e inorgânicos (C-inorg., $\mathrm{N}$-inorg. e P-inorg.). Valores médios ( \pm desvio padrão) de quatro repetições, expressos em relação ao total de massa seca

\begin{tabular}{|c|c|c|c|c|c|c|c|c|c|}
\hline Biossólido $^{a}$ & C-total & C-org. & C-inorg. & N-total & N-org. & $\mathrm{N}$-inorg. & P-total & P-org. & P-inorg. \\
\hline & & & & & $\mathrm{c}^{-1}$ & & & & \\
\hline \multirow[b]{2}{*}{ BAC } & 185,93 & 135,86 & 50,06 & 18,10 & 17,56 & 0,54 & 7,92 & 2,09 & 5,53 \\
\hline & $( \pm 2,15)$ & $( \pm 7,34)$ & $( \pm 6,73)$ & $( \pm 0,52)$ & $( \pm 0,54)$ & $( \pm 0,11)$ & $( \pm 0,17)$ & $( \pm 0,14)$ & $( \pm 0,13)$ \\
\hline \multirow[b]{2}{*}{ BAP } & 311,55 & 301,47 & 10,08 & 42,08 & 37,66 & 4,41 & 17,96 & 8,24 & 9,72 \\
\hline & $( \pm 9,22)$ & $( \pm 8,17)$ & $( \pm 1,22)$ & $( \pm 1,13)$ & $( \pm 1,16)$ & $( \pm 0,19)$ & $( \pm 0,82)$ & $( \pm 1,38)$ & $( \pm 0,26)$ \\
\hline \multirow[b]{2}{*}{ BAS } & 345,70 & 337,24 & 8,46 & 42,63 & 39,02 & 3,61 & 17,01 & 12,96 & 4,12 \\
\hline & $( \pm 4,57)$ & $( \pm 6,28)$ & $( \pm 1,45)$ & $( \pm 0,71)$ & $( \pm 0,59)$ & $( \pm 0,16)$ & $( \pm 0,39)$ & $( \pm 3,39)$ & $( \pm 0,62)$ \\
\hline \multirow[b]{2}{*}{ BLB } & 314,80 & 308,52 & 6,28 & 27,18 & 25,10 & 2,08 & 5,50 & 1,56 & 3,94 \\
\hline & $( \pm 10,04)$ & $( \pm 9,54)$ & $( \pm 0,97)$ & $( \pm 0,54)$ & $( \pm 0,50)$ & $( \pm 0,16)$ & $( \pm 0,27)$ & $( \pm 0,24)$ & $( \pm 0,06)$ \\
\hline \multirow[b]{2}{*}{ CL } & 217,45 & 208,53 & 8,92 & 17,40 & 14,72 & 2,68 & 3,80 & 1,14 & 2,66 \\
\hline & $( \pm 9,04)$ & $( \pm 9,10)$ & $( \pm 0,96)$ & $( \pm 0,59)$ & $( \pm 0,55)$ & $( \pm 0,29)$ & $( \pm 0,21)$ & $( \pm 0,20)$ & $( \pm 0,13)$ \\
\hline
\end{tabular}

${ }^{a}$ BAC = biossólido anaeróbio condicionado com cal e cloreto férrico; BAP = biossólido anaeróbio condicionado com polímero sintético; BAS = biossólido anaeróbio seco termicamente; BLP = biossólido proveniente de lagoas de estabilização e condicionado com polímero sintético; e CL = composto de lodo de esgoto obtido por compostagem em pilhas aeradas após mistura do BLP com bagaço de cana e restos de poda urbana.

Dentre os biossólidos de reator anaeróbio, a secagem térmica parece conservar a maior parte do $\mathrm{C}$, do $\mathrm{N}$ e do $\mathrm{P}$ em compostos orgânicos, enquanto que o condicionamento químico com cal e cloreto férrico exibe tendência contrária, isto é, conduzir à predominância dos elementos sob formas inorgânicas. Pode-se supor que a secagem térmica, caracterizada por uma redução mais rápida e eficiente do teor de água do resíduo (David, 2002), paralisa a atividade microbiana, preservando os compostos orgânicos presentes. 
O processo de compostagem do biossólido BLP para obtenção do CL proporcionou redução dos teores totais de C, $\mathrm{N}$ e P, e de C e N presentes em compostos orgânicos, o que se deve a provável combinação de dois fatores principais: (i) diluição das quantidades de $\mathrm{N}$ e P pela mistura de materiais vegetais de elevada relação $\mathrm{C} / \mathrm{N}$ e pobres em P (Rowell et al., 2001; Brady \& Weil, 2002; Silva et al., 2002), comparado ao biossólido BLP; e (ii) degradação parcial do carbono durante o processo de compostagem.

A relação $\mathrm{C} / \mathrm{N}$ foi semelhante entre os biossólidos de mesma origem, indicando que a etapa de condicionamento químico e a etapa complementar não alteraram tal relação (Tabela 12). Os valores da relação $\mathrm{C} / \mathrm{N}$, em média 8 para os biossólidos de reator anaeróbio e 11 para o BLP e para o CL, encontram-se em concordância com o que é citado em trabalhos da literatura nacional (Barreto, 1995; Silva, 1995; Bertoncini, 1997; Pires, 1998; Andrade, 1999; Anjos, 1999; Canellas et al., 2000; Oliveira, 2000; Santos et al., 2002; Simonete et al., 2003) e internacional (Hsieh et al., 1981; Hernández et al., 1990; Ajwa \& Tabatabai, 1994; Gilmour et al., 1996a; Bernal et al., 1998a; Hérnández-Apaolaza et al., 2000; Rowell et al., 2001). No caso do biossólido compostado, a relação $\mathrm{C} / \mathrm{N}$ igual a 12 encontra-se no limite do valor aceitável (C/N = 12), citado por Bernal et al. (1998b), para compostos orgânicos maturados preparados a partir da mistura de uma ampla gama de resíduos orgânicos, incluindo biossólidos.

Na Tabela 6 são apresentados os resultados da determinação dos teores de carbono solúvel em água (C-solúvel). Os valores de C-solúvel para todos os biossólidos podem ser considerados baixos em comparação ao que é reportado por Moral et al. (2002) para estercos de animais, cujos valores médios variaram entre 7,8 e $24,6 \mathrm{~g} \mathrm{~kg}^{-1}$ (base seca). Baixos teores de C-solúvel em biossólidos podem ser explicados parcialmente pela perda da maior parte dos compostos orgânicos solúveis durante o processo de concentração dos sólidos nas estações ou durante a estocagem, por lixiviação (Piotrowski et al., 1984). 
Tabela 6. Teor de carbono solúvel em água (C-solúvel) expresso em relação a massa seca e como porcentagem do total de carbono orgânico. Valores médios ( \pm desvio padrão) de quatro repetições

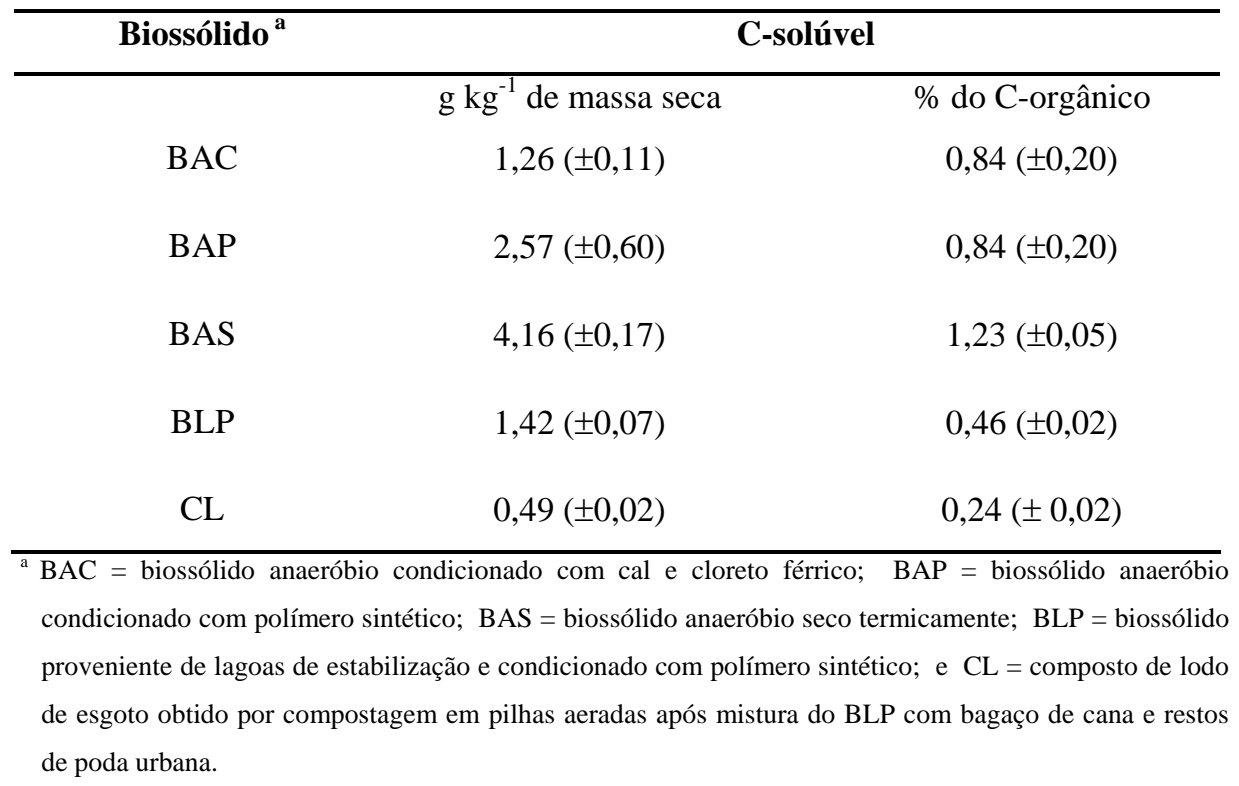

O maior teor de C-solúvel no BAS, expresso como porcentagem do total de C-orgânico, comparado aos valores calculados para o BAC e BAP (Tabela 6), confirma a tendência da secagem térmica do biossólido em conservar os compostos orgânicos, como comentado anteriormente. Os teores de C-solúvel no BAC e no BAP foram de 1,26 e $2,57 \mathrm{~g} \mathrm{~kg}^{-1}$ (base seca), respectivamente, mas quando expressos em relação ao total de C-orgânico, os valores foram semelhantes, 0,84 \%. Isso significa que o teor total de C-orgânico (Tabela 5) foi alterado em função dos processos diferenciados de condicionamento químico para desidratação dos biossólidos (Tabela 3), mas estes processos não influenciaram a qualidade da $\mathrm{MO}$, pelo menos no que se refere ao teor de C-solúvel. Quando expressos como porcentagem do total de C-orgânico, os teores de C-solúvel do BLP e CL foram os menores dentre os biossólidos estudados (Tabela 6). Do total de C-orgânico do BLP, em média 0,46 \% foi solúvel em água, valor este 2 a 2,5 vezes inferior aos valores médios calculados para os biossólidos provenientes de reator anaeróbio. Para o CL, cujo valor de C-solúvel representou 0,24 \% do total de C-orgânico, tais diferenças variaram de 3 a 5 vezes, em relação aos biossólidos de reator 
anaeróbio, e de 2 vezes em relação ao BLP. A fração de carbono solúvel em água compreende uma série de compostos (açúcares simples, ácidos orgânicos, aminoácidos, peptídeos e proteínas p.e.) que podem ser caracterizados como facilmente degradáveis pela microbiota (Moral et al., 2002) e, nesse sentido, menores valores desses compostos nos biossólidos BLP e CL eram esperados, função do tempo de duração do tratamento e dos processos biológicos mais intensos á que foram submetidos na ETE (Tabela 3). Leita \& De Nobili (1991), estudando a fração de carbono solúvel em água durante a compostagem para obtenção de um composto de lixo verificou que em poucos dias do processo, o teor de carbono solúvel em água foi reduzido pela metade, sendo as quantidades de polissacarídeos, peptídeos e aminoácidos responsáveis pela maior proporção do decréscimo observado.

\subsubsection{Fracionamento químico do carbono}

Historicamente, muitos procedimentos analíticos têm buscado quantificar todo o carbono orgânico de amostras de solos e resíduos orgânicos (Walkley \& Black, 1934; Nelson \& Sommers, 1975; Heanes, 1984; Ciavatta et al., 1989; Soon \& Aboud, 1991; Eaton et al., 1995), mas determinações de frações de carbono com diferentes graus de oxidação, no caso de amostras de solo, podem constituir importante ferramenta para diagnóstico de alterações do pool orgânico, melhor relacionadas a processos químicos e físico edáficos de real interesse (Lefroy et al., 1993; Blair et al., 1995; Blair et al., 1998; Chan et al., 2001). Nesse sentido, o procedimento de fracionamento do carbono foi utilizado no presente estudo como ferramenta auxiliar na compreensão da dinâmica de degradação da fração orgânica de biossólidos após aplicação no solo. Também foi objetivo verificar se o método de fracionamento desenvolvido para amostras de solo (Chan et al., 2001), é válido no caso de amostras de biossólidos.

O fracionamento químico do carbono presente nos biossólidos, segundo diferentes graus de oxidação, revelou predominância da fração resistente nos biossólidos BAP e BAS, e da fração lábil nos biossólidos BLP e CL (Tabela 7). À princípio, parece contraditório ao discutido para o C-solúvel (item 3.3.1.1). No entanto, os resíduos BLP e CL, por serem resultantes de processos bioxidativos mais intensos (Tabela 3), devem 
apresentar maior proporção de compostos orgânicos simples, originados da quebra de compostos mais complexos (Bertoldi et al., 1984), em contraposição aos biossólidos de reator anaeróbio BAP e BAS. A oxidação do carbono usando dicromato de potássio em meio ácido, originalmente desenvolvida por Walkley \& Black (1934), para amostras de solo, não recupera todo C-orgânico da amostra, embora as formas mais ativas de C-orgânico sejam convertidas em $\mathrm{CO}_{2}$ (Nelson \& Sommers, 1996). Elevados valores de recuperação do carbono usando o método clássico de Walkley \& Black (1934) em amostras de solo se deve a baixos teores de C-orgânico nas amostras e/ou relativo acúmulo de moléculas de baixo peso molecular (Broadbent, 1953; Olayinka et al., 1998). No caso de biossólidos, a segunda justificativa torna-se importante, uma vez que compostos orgânicos de elevado peso molecular são formados a medida em que a MO é decomposta é humificada (Stevenson, 1994). Pode-se supor, desse modo, que a quebra parcial de compostos orgânicos complexos nos biossólidos BLP e CL, função do tratamento recebido, aumenta a quantidade de compostos de menor peso molecular, que são mais facilmente oxidados. Adicionalmente, a porcentagem de C-lábil no CL foi igual 58,82 \% do total de carbono orgânico, enquanto no BLP esse valor foi de 42,51 \%, ou seja, levemente inferior ao CL, acompanhando o suposto menor grau de decomposição da MO do resíduo (Tabela 3).

Deve-se ressaltar ainda que o carbono solúvel em água representaria apenas uma pequena parte da fração lábil de carbono, quantificada no procedimento de fracionamento utilizado: 2,$5 ; 3,1 ; 3,9 ; 1,1$; e $0,4 \%$, respectivamente para os biossólidos BAC, BAP, BAS, BLP e CL. 
Tabela 7. Frações do carbono orgânico presente nos biossólidos, determinadas em função de diferentes graus de oxidação. Valores médios ( \pm desvio padrão) de quatro repetições

\begin{tabular}{|c|c|c|c|}
\hline Biossólido $^{a}$ & C-lábil & C-médio & C-resistente \\
\hline & \multicolumn{3}{|c|}{ - } \\
\hline BAC & $49,34( \pm 2,63)$ & $46,53( \pm 4,00)$ & $40,00( \pm 7,84)$ \\
\hline BAP & $83,17( \pm 2,93)$ & $88,14( \pm 10,51)$ & $130,16( \pm 11,47)$ \\
\hline BAS & $105,66( \pm 8,15)$ & $74,20( \pm 16,68)$ & $157,38( \pm 18,04)$ \\
\hline BLP & $131,04( \pm 1,77)$ & $64,97( \pm 11,96)$ & $112,51( \pm 8,49)$ \\
\hline CL & $122,61( \pm 7,90)$ & $32,79( \pm 11,84)$ & $53,13( \pm 7,33)$ \\
\hline BAC & $36,38( \pm 2,46)$ & $34,35( \pm 4,01)$ & $29,27( \pm 4,31)$ \\
\hline BAP & $27,60( \pm 1,15)$ & $29,25( \pm 3,50)$ & $43,15( \pm 3,17)$ \\
\hline BAS & $31,32( \pm 2,05)$ & $22,05( \pm 5,28)$ & $46,63( \pm 4,94)$ \\
\hline BLP & $42,51( \pm 1,74)$ & $21,02( \pm 3,47)$ & $36,47( \pm 2,58)$ \\
\hline CL & $58,82( \pm 3,41)$ & $15,72( \pm 5,60)$ & $25,46( \pm 3,13)$ \\
\hline
\end{tabular}

\footnotetext{
${ }^{a}$ BAC = biossólido anaeróbio condicionado com cal e cloreto férrico; BAP = biossólido anaeróbio condicionado com polímero sintético; BAS = biossólido anaeróbio seco termicamente; BLP = biossólido proveniente de lagoas de estabilização e condicionado com polímero sintético; e CL = composto de lodo de esgoto obtido por compostagem em pilhas aeradas após mistura do BLP com bagaço de cana e restos de poda urbana.
}

\subsubsection{Compostos orgânicos}

Os teores dos compostos orgânicos determinados nos biossólidos e expressos em relação ao total de massa seca são mostrados na Tabela 8. Na Tabela 9 é apresentada a composição química da MO dos biossólidos, bem como o teor total de MO.

O teor de MO variou entre os resíduos, com valores médios iguais a 555,15 g $\mathrm{kg}^{-1}$ para os biossólidos BAP, BAS e BLP, 398,94 $\mathrm{g} \mathrm{kg}^{-1}$ para o CL e 263,69 $\mathrm{g} \mathrm{kg}^{-1}$ para o BAC (Tabela 9). Variações no conteúdo orgânico de biossólidos são atribuídas a carga inorgânica nos esgotos (Hattori \& Mukai, 1986), bem como ao processo de tratamento nas ETEs (Mitchell et al., 1978). No caso do BAC, presume-se que a adição de cal e 
cloreto férrico (Tabela 3) deve ter sido determinante no baixo teor de MO do resíduo, uma vez que há formação de material inorgânico, principalmente carbonatos, diluindo a MO na massa total obtida após condicionamento e desidratação mecânica. Para o CL, é provável que processo de compostagem tenha sido responsável pela redução do teor de MO, em comparação ao BLP.

Tabela 8. Teores de alguns compostos orgânicos nos biossólidos. Valores médios ( \pm desvio padrão) de quatro repetições, expressos em relação ao total de massa seca dos resíduos

\begin{tabular}{|c|c|c|c|c|c|c|c|c|}
\hline Bioss. $^{\text {a }}$ & Açúcares & PB & Lipídeos & Hemicel. & Celulose & Lignina & Fenóis & Taninos \\
\hline BAC & $\begin{array}{c}0,13 \\
( \pm 0,02)\end{array}$ & $\begin{array}{l}111,64 \\
( \pm 7,83)\end{array}$ & $\begin{array}{c}19,71 \\
( \pm 1,23)\end{array}$ & $\begin{array}{c}79,37 \\
( \pm 4,72)\end{array}$ & $\begin{array}{c}17,50 \\
( \pm 3,30)\end{array}$ & $\begin{array}{c}10,61 \\
( \pm 3,32)\end{array}$ & $\begin{array}{c}0,09 \\
( \pm 0,01)\end{array}$ & $\begin{array}{c}0,03 \\
( \pm 0,01)\end{array}$ \\
\hline BAP & $\begin{array}{c}0,13 \\
( \pm 0,02)\end{array}$ & $\begin{array}{c}226,97 \\
( \pm 10,17)\end{array}$ & $\begin{array}{c}44,10 \\
( \pm 1,08)\end{array}$ & $\begin{array}{c}96,84 \\
( \pm 20,39)\end{array}$ & $\begin{array}{c}26,37 \\
( \pm 7,25)\end{array}$ & $\begin{array}{r}167,23 \\
( \pm 13,81)\end{array}$ & $\begin{array}{c}0,17 \\
( \pm 0,02)\end{array}$ & $\begin{array}{c}0,11 \\
( \pm 0,01)\end{array}$ \\
\hline BAS & $\begin{array}{c}0,28 \\
( \pm 0,02)\end{array}$ & $\begin{array}{c}241,14 \\
( \pm 11,78)\end{array}$ & $\begin{array}{c}75,90 \\
( \pm 3,35)\end{array}$ & $\begin{array}{c}72,67 \\
( \pm 12,27)\end{array}$ & $\begin{array}{c}53,22 \\
( \pm 17,12)\end{array}$ & $\begin{array}{c}122,64 \\
( \pm 20,79)\end{array}$ & $\begin{array}{c}0,21 \\
( \pm 0,01)\end{array}$ & $\begin{array}{c}0,09 \\
( \pm 0,02)\end{array}$ \\
\hline BLP & $\begin{array}{c}0,20 \\
( \pm 0,04)\end{array}$ & $\begin{array}{c}152,50 \\
( \pm 18,32)\end{array}$ & $\begin{array}{c}22,09 \\
( \pm 0,47)\end{array}$ & $\begin{array}{c}23,99 \\
( \pm 11,90)\end{array}$ & $\begin{array}{c}151,23 \\
( \pm 20,40)\end{array}$ & $\begin{array}{r}163,10 \\
( \pm 30,38)\end{array}$ & $\begin{array}{c}0,38 \\
( \pm 0,02)\end{array}$ & $\begin{array}{c}0,22 \\
( \pm 0,01)\end{array}$ \\
\hline CL & $\begin{array}{c}0,13 \\
( \pm 0,01)\end{array}$ & $\begin{array}{c}100,50 \\
( \pm 25,19)\end{array}$ & $\begin{array}{c}10,42 \\
( \pm 0,96)\end{array}$ & $\begin{array}{c}12,97 \\
( \pm 4,96)\end{array}$ & $\begin{array}{r}158,23 \\
( \pm 3,99)\end{array}$ & $\begin{array}{c}87,59 \\
( \pm 5,19)\end{array}$ & $\begin{array}{c}0,28 \\
( \pm 0,04)\end{array}$ & $\begin{array}{c}0,17 \\
( \pm 0,02)\end{array}$ \\
\hline
\end{tabular}

${ }^{\mathrm{a}} \mathrm{BAC}$ = biossólido anaeróbio condicionado com cal e cloreto férrico; BAP = biossólido anaeróbio condicionado com polímero sintético; $\quad$ BAS = biossólido anaeróbio seco termicamente; BLP = biossólido proveniente de lagoas de estabilização e condicionado com polímero sintético; e CL = composto de lodo de esgoto obtido por compostagem em pilhas aeradas após mistura do BLP com bagaço de cana e restos de poda urbana. 
Tabela 9. Composição química da matéria orgânica (MO) dos biossólidos. Valores médios ( \pm desvio padrão) de quatro repetições, expressos como porcentagem do total de MO dos resíduos

\begin{tabular}{|c|c|c|c|c|c|c|c|c|c|}
\hline Bioss. $^{a}$ & MO & Açúcares & PB & Lipídeos & Hemicel. & Celulose & Lignina & Fenóis & Taninos \\
\hline & $\mathrm{g} \mathrm{kg}^{-1}$ & & & & $-\%$ & & & & \\
\hline \multirow[b]{2}{*}{ BAC } & 263,59 & 0,05 & 42,60 & 7,53 & 30,55 & 6,63 & 4,05 & 0,03 & 0,01 \\
\hline & $( \pm 30,42)$ & $( \pm 0,01)$ & $( \pm 6,73)$ & $( \pm 0,77)$ & $( \pm 5,15)$ & $( \pm 0,93)$ & $( \pm 1,37)$ & $( \pm 0,01)$ & $( \pm 0,00)$ \\
\hline \multirow[b]{2}{*}{ BAP } & 553,55 & 0,02 & 41,60 & 7,97 & 17,50 & 4,76 & 30,21 & 0,03 & 0,02 \\
\hline & $( \pm 1,63)$ & $( \pm 0,00)$ & $( \pm 1,86)$ & $( \pm 0,22)$ & $( \pm 3,72)$ & $( \pm 1,30)$ & $( \pm 2,48)$ & $( \pm 0,00)$ & $( \pm 0,00)$ \\
\hline \multirow[b]{2}{*}{ BAS } & 575,09 & 0,05 & 42,22 & 13,20 & 12,64 & 9,26 & 21,33 & 0,04 & 0,02 \\
\hline & $( \pm 0,89)$ & $( \pm 0,00)$ & $( \pm 2,01)$ & $( \pm 0,59)$ & $( \pm 2,13)$ & $( \pm 2,97)$ & $( \pm 3,63)$ & $( \pm 0,00)$ & $( \pm 0,00)$ \\
\hline \multirow[b]{2}{*}{ BLP } & 536,81 & 0,04 & 27,65 & 4,15 & 4,59 & 28,57 & 30,63 & 0,07 & 0,04 \\
\hline & $( \pm 67,75)$ & $( \pm 0,00)$ & $( \pm 5,94)$ & $( \pm 0,40)$ & $( \pm 2,54)$ & $( \pm 5,67)$ & $( \pm 5,44)$ & $( \pm 0,01)$ & $( \pm 0,01)$ \\
\hline \multirow[b]{2}{*}{ CL } & 398,94 & 0,03 & 25,38 & 2,61 & 3,25 & 39,67 & 21,96 & 0,07 & 0,04 \\
\hline & $( \pm 6,12)$ & $( \pm 0,00)$ & $( \pm 0,71)$ & $( \pm 0,24)$ & $( \pm 1,24)$ & $( \pm 1,35)$ & $( \pm 1,43)$ & $( \pm 0,01)$ & $( \pm 0,01)$ \\
\hline
\end{tabular}

A análise conjunta dos resultados (Tabelas 8 e 9) evidencia que proteína bruta, hemicelulose e lignina predominam nos biossólidos provenientes de reator anaeróbio (BAC, BAP e BAS), sendo que o teor de lipídeo é também bastante expressivo no caso do BAC e do BAS (Tabela 9). Para o BLP e o CL os teores de proteína bruta, celulose e lignina são os que se destacam. Resultados da literatura têm confirmado a presença predominante de proteína dentre os compostos orgânicos em amostras de biossólidos (Hattori \& Mukai, 1986; Deiana et al., 1990; Hernández et al., 1990; Rowell et al., 2001). Quando o teor de proteína bruta é calculado usando-se o valor de $\mathrm{N}$-Kjeldhal, conforme o método usado neste trabalho, multiplica-se o teor de $\mathrm{N}$ por 6,25 (fator que corresponde ao teor médio de 16 \% de N em proteínas). É plausível, portanto, pensar na ocorrência de mascaramento dos reais valores de proteína na 
amostra, devido a contribuição do $\mathrm{N}$ presente em compostos inorgânicos. No entanto, observando-se os resultados da Tabela 5, vê-se que para todos os biossólidos estudados, a maior parte do $\mathrm{N}$ esteve presente em compostos orgânicos e este foi proporcional ao teor total do elemento. Estudos usando a técnica de ressonância magnética nuclear com monitoramento dos núcleos de ${ }^{13} \mathrm{C}\left(\mathrm{RMN}^{13} \mathrm{C}\right)$ evidenciam a existência de relação positiva entre o teor de N-orgânico e índices protéicos de NMR- ${ }^{13} \mathrm{C}$, sugerindo que a maior parte do N-orgânico dos biossólidos ocorre no pool protéico (Deiana et al., 1990; Rowell et al., 2001). Rowell et al. (2001) relacionaram o teor de proteína no biossólido com o tipo de tratamento na estação: (i) biossólidos provenientes de sistemas aeróbios exibem menores teores de proteínas e aumento da relação $\mathrm{C} / \mathrm{N}$ em comparação a biossólidos de sistemas anaeróbios; (ii) o aumento do tempo de detenção nos tanques anaeróbios reduz o teor de proteína; e (iii) a temperatura em que o processo de digestão anaeróbia é mantido, correlaciona inversamente com o teor protéico do resíduo. Essas considerações podem ser estendidas aos biossólidos aqui estudados. Os biossólidos de reator anaeróbio exibiram maiores teores de proteína (Tabela 9) e menores valores de relação C/N (Tabela 12), em comparação ao BLP e ao CL, cujo processo de obtenção na ETE envolveu fases aeróbias (Tabela 3); revolvimento para secagem e compostagem, respectivamente.

Hattori \& Mukai (1986), estudando seis biossólidos; três condicionados com cal hidratada e cloreto férrico, três condicionados com polímero e um sem condicionamento, encontraram proteína (32,61 \pm 13,33 \%), lignina (22,25 \pm 7,33 \%) e lipídios (15,07 \pm 4,57 \%), figurando como os principais componentes orgânicos nos resíduos, independente do condicionamento químico usado. Tais resultados estão em concordância com os aqui apresentados, exceto pelos teores de lipídios (Tabela 9) que foram substancialmente inferiores aos encontrados por Hattori \& Mukai (1986). Outros resultados da literatura também incluem os lipídios entre os compostos orgânicos predominantes em biossólidos (Hohla et al., 1978; Terry et al., 1979a; Rowell et al., 2001). Essas diferenças devem estar relacionadas aos métodos empregados nos estudos. 
A MO do BLP e do CL foi mais enriquecida em celulose e menos em hemicelulose, em comparação a MO dos biossólidos BAC, BAP e BAS (Tabela 9). O elevado teor de celulose no CL ocorreu provavelmente devido a mistura de materiais de origem vegetal para a compostagem do biossólido. A celulose compreende cerca de 50 a $70 \%$ do total de massa seca das plantas, ocorrendo predominantemente na parede celular (Mason, 1980). Rowell et al. (2001) encontraram teores elevados de carboidratos (celulose + hemicelulose) em amostras sólidas de biossólidos analisadas por meio de $\mathrm{RMN}-{ }^{13} \mathrm{C}$, correlacionados com os resultados desses compostos determinados por meio de procedimentos químicos baseados em seqüências de solubilizações e extrações (análises aproximadas), semelhante aos utilizados no presente estudo.

Em comparação aos teores de açúcares solúveis comumente encontrados em materiais vegetais, em média 5 \% do total de MO (Brady \& Weil, 2002), e no solo, de 0,2 a 0,3 \% do total de MO (Greenland \& Oades, 1975), os valores determinados nos biossólidos (Tabela 9) podem ser considerados baixos. A pequena participação dos açúcares solúveis no total de MO dos resíduos (Tabela 8) era esperada, considerando a biodegradabilidade desses compostos (Greenland \& Oades, 1975) e os processos de degradação parcial do conteúdo orgânico nas estações, bem como a solubilidade em água, que pode ter determinado a permanência preferencial desses compostos no efluente de esgoto tratado (Piotrowski et al., 1984), semelhante ao comentado para o C-solúvel (item 3.3.1.1).

As concentrações de fenóis e taninos foram da mesma ordem dos teores de carboidratos (Tabelas 8 e 9). Os biossólidos BLP e o CL apresentaram os maiores teores de taninos e fenóis na MO (Tabela 9), com média de 0,07 \% para fenóis e 0,04 \% para taninos. Para os biossólidos de reator anaeróbio os valores de fenóis estiveram entre 0,03 e $0,04 \%$, e de taninos entre 0,01 e $0,02 \%$. 


\subsubsection{Degradação da matéria orgânica dos biossólidos}

\subsubsection{Carbono emanado na forma de $\mathrm{CO}_{2}$}

Na Figura 2 são mostrados os resultados de $\mathrm{C}-\mathrm{CO}_{2}$ emanado acumulado do controle (somente solo) e das misturas de solo e biossólidos. Na dose de $40 \mathrm{t} \mathrm{ha}^{-1}$, os biossólidos provenientes de reator anaeróbio foram os que apresentaram maiores valores de $\mathrm{C}-\mathrm{CO}_{2}$ emanado, enquanto que o biossólido compostado (CL), os menores valores (Figura 2A). Durante os primeiros dez dias de incubação os biossólidos BAS e BAP proporcionaram semelhante liberação de $\mathrm{C}-\mathrm{CO}_{2}$, diferindo posteriormente, com maior liberação de $\mathrm{C}-\mathrm{CO}_{2}$ no tratamento com BAS. Nesse período inicial, no tratamento com o BAC houve a pequena liberação de $\mathrm{C}-\mathrm{CO}_{2}$, sendo inclusive inferior ao CL durante os sete primeiros dias. A incorporação do BAC induziu a chamada lag-fase, uma fase de adaptação da comunidade microbiana as novas condições do meio. A indução da lag-fase verificada no solo tratado com o BAC ocorreu provavelmente devido a elevada alcalinidade do resíduo e/ou teor de sais solúveis (Tabela 4), uma vez que a origem e tratamento dos esgotos é idêntica a dos biossólidos BAS e BAP (Tabela 3). Portanto, a aplicação no solo do biossólido de reator anaeróbio condicionado com cal e cloreto férrico (BAC) produziu efeito depressivo e transiente na atividade microbiana edáfica, o que não foi verificado quando o resíduo foi condicionado com polímero ou condicionado com polímero e seco termicamente.

Comparando-se as quantidades totais de $\mathrm{C}-\mathrm{CO}_{2}$ emanadas a partir das amostras de solo tratadas com BLP e com CL, ao final do período de incubação (Figura 2A), 1564 e $954 \mathrm{mg} \mathrm{kg}{ }^{-1}$, respectivamente, pode-se verificar que o processo de compostagem do biossólido proporcionou redução da quantidade de $\mathrm{C}-\mathrm{CO}_{2}$ emanada da mistura solo/resíduo, em comparação ao biossólido sem compostagem.

A aplicação de doses crescentes do BAP, até $80 \mathrm{t} \mathrm{ha}^{-1}$, proporcionou incrementos nas quantidades de $\mathrm{C}-\mathrm{CO}_{2}$ emanadas das misturas, o que é coerente com diversos trabalhos da literatura (Tester et al., 1977; Hsieh et al., 1981; Tester \& Parr, 1983; Hattori \& Mukai, 1986; Pires et al., 2002; Santos et al., 2002). 
As diferenças verificadas entre a quantidades de $\mathrm{C}-\mathrm{CO}_{2}$ emanadas nos tratamentos com biossólidos e do solo controle, indicam a contribuição positiva dos resíduos na atividade microbiana edáfica.
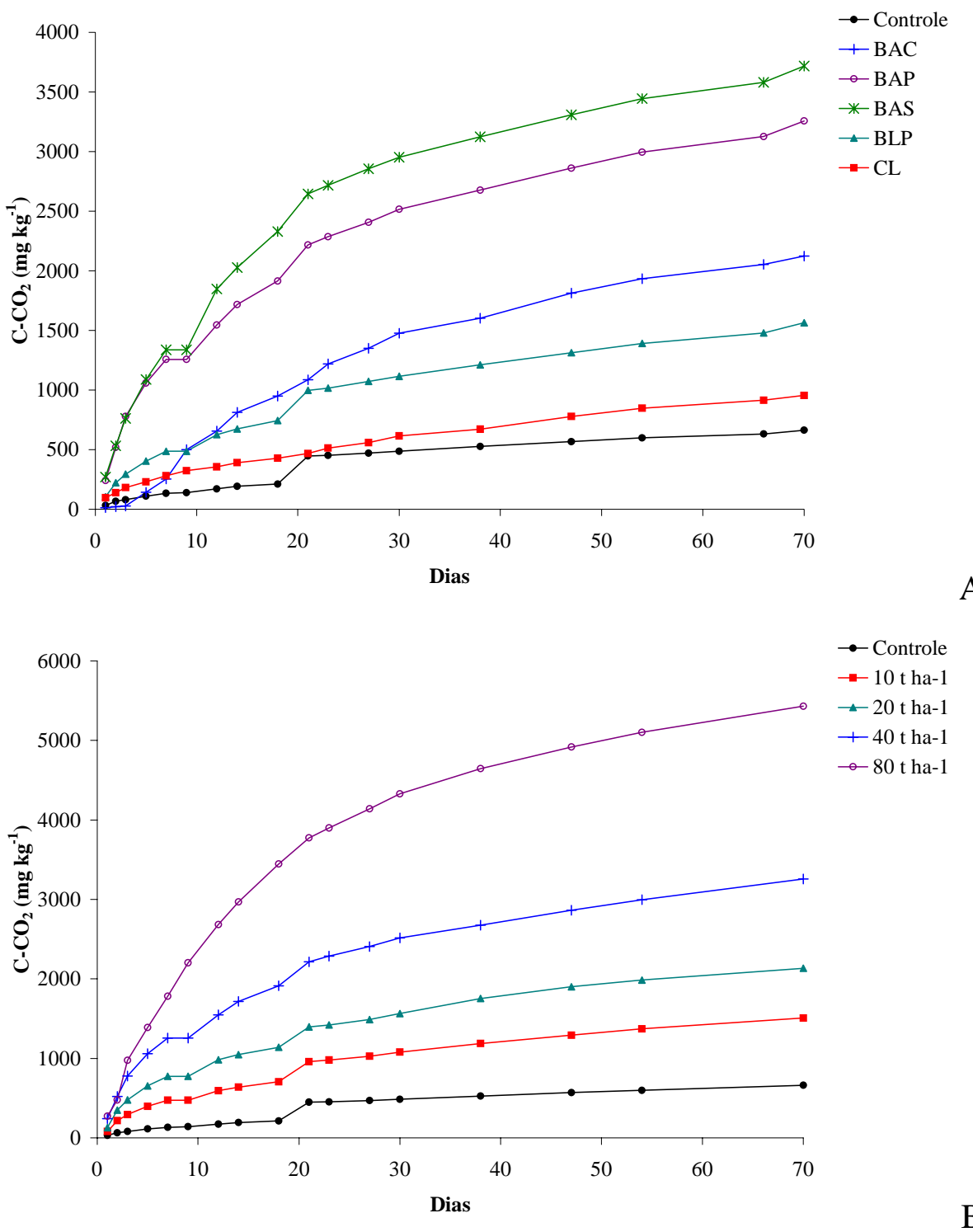

A

B

Figura 2 - Quantidades de carbono emanado acumulado, na forma de $\mathrm{CO}_{2}$ $\left(\mathrm{C}-\mathrm{CO}_{2}\right)$, a partir do solo controle e das misturas de solo e biossólidos, durante 70 dias de incubação: A- resultados dos cinco biossólidos na dose referência de $40 \mathrm{t} \mathrm{ha}^{-1} \mathrm{e}$; B- resultados do biossólido anaeróbio condicionado com polímero sintético (BAP) aplicado nas doses de 10, 20, 40, e $80 \mathrm{t} \mathrm{ha}^{-1}$ 
3.3.2.2 Taxa de degradação da matéria orgânica dos biossólidos

A degradação da MO dos resíduos aplicados ao solo na dose de $40 \mathrm{t} \mathrm{ha}^{-1}$ foi semelhante entre os biossólidos provenientes do tratamento dos esgotos em sistema de lodos ativados e reator anaeróbio (BAC, BAP e BAS), independente do processo de condicionamento para desidratação, ou etapa complementar (Tabela 10). O valor médio da taxa de degradação dos três biossólidos, após 70 dias de incubação, foi de 21,63 \%, em concordância a outros resultados de literatura. Pires et al. (2002) e Santos et al. (2002), trabalhando com doses de biossólidos digeridos anaeróbios, misturadas a amostras de um solo de textura média, chegaram a taxas de degradação entre 12,4 e 24,9 \%, para biossólidos condicionados com cal, e entre 20,0 e 24,9 \% para biossólidos condicionados com polímero, à depender da dose aplicada e para 70 dias de avaliação. Comparativamente, no trabalho de Santos et al. (2002), os autores avaliaram a degradação de uma amostra de torta de filtro da indústria da cana-de-açúcar, obtendo, em 70 dias de incubação, valor médio da taxa de degradação igual a 31,59 \%, superior aos valores observados para os biossólidos.

Tabela 10. Taxas de degradação dos biossólidos, nas doses testadas, após 70 dias de incubação. Valores médios de C-emanado e taxas de degradação ( \pm desvio padrão)

\begin{tabular}{|c|c|c|c|c|}
\hline Biossólido $^{\text {a }}$ & Dose & C-adicionado & C-emanado & Taxa de degradação \\
\hline & --- t ha' ${ }^{-1}--$ & ------- $\mathrm{mg} \mathrm{kg}^{-1}$------- & ------- $\mathrm{mg} \mathrm{kg}^{-1}$------ & ---------- \% ----- \\
\hline BAC & 40 & 7437,20 & $1636,47( \pm 17,69)$ & $22,00( \pm 0,24)$ \\
\hline BAP & 40 & 12462,00 & $2592,78( \pm 185,77)$ & $20,81( \pm 1,49)$ \\
\hline BAS & 40 & 13828,00 & $3054,51( \pm 97,47)$ & $22,09( \pm 0,70)$ \\
\hline BLP & 40 & 12592,00 & $901,12( \pm 16,64)$ & $7,16( \pm 0,13)$ \\
\hline CL & 40 & 8698,00 & $467,84( \pm 7,54)$ & $5,38( \pm 0,09)$ \\
\hline BAP & 10 & 3115,50 & $846,53( \pm 22,28)$ & $27,17( \pm 0,72)$ \\
\hline BAP & 20 & 6231,00 & $1472,56( \pm 35,63)$ & $23,63( \pm 0,57)$ \\
\hline BAP & 80 & 24924,00 & $4768,20( \pm 30,86)$ & $19,13( \pm 0,12)$ \\
\hline
\end{tabular}

\footnotetext{
$\overline{~ a ~ B A C ~=~ b i o s s o ́ l i d o ~ a n a e r o ́ b i o ~ c o n d i c i o n a d o ~ c o m ~ c a l ~ e ~ c l o r e t o ~ f e ́ r r i c o ; ~ B A P ~=~ b i o s s o ́ l i d o ~ a n a e r o ́ b i o ~ c o n d i c i o n a d o ~ c o m ~}$ polímero sintético; BAS = biossólido anaeróbio seco termicamente; BLP = biossólido proveniente de lagoas de estabilização e condicionado com polímero sintético; e $C L=$ composto de lodo de esgoto obtido por compostagem em pilhas aeradas após mistura do BLP com bagaço de cana e restos de poda urbana.
} 
Os biossólidos BLP e CL exibiram as menores taxas de degradação, 7,16 e 5,38 \%, respectivamente (Tabela 10). Menores taxas de degradação desses resíduos eram esperadas em função do processo de obtenção dos mesmos. O BLP é um biossólido com tempo de detenção de cerca de um ano em lagoas de decantação e posterior "fase aeróbia", em que o material é disposto pilhas longitudinais, revolvidas periodicamente durante 120 dias, visando a desidratação. O CL tem a mesma origem do BLP, porém ao invés da desidratação, o biossólido foi misturado com bagaço de cana-de-açúcar e restos de poda urbana para compostagem durante 90 dias. Em ambos os casos supõem-se que o material orgânico resultante seja biologicamente mais estabilizado, em comparação aos biossólidos de reator anaeróbio, e, por isso, com menor degradação após aplicação no solo. A compostagem de biossólidos possibilita a formação de substâncias húmicas mais estáveis, as quais são menos efetivas como substrato orgânico e como fonte de energia aos microorganismos (Hernández-Apaolaza et al., 2000). A compostagem de biossólidos constitui processo que maximiza a decomposição dos componentes orgânicos pela oxidação e metabolismo por microrganismos, reduzindo a quantidade de carbonos em compostos alifáticos e aumentando nos compostos aromáticos (Piotrowski et al., 1984). Tester et al. (1979) reportam taxas de degradação de 6,3 a 6,9 \%, em 45 dias de incubação, a partir de amostras de solo tratadas com composto orgânico obtido por meio de compostagem de um biossólido alcalino, misturado com cavacos de madeira (relação $2,5: 1$ ).

Com o aumento da dose do BLP, houve redução da taxa de degradação, de 27,17\% na dose $10 \mathrm{t} \mathrm{ha}^{-1}$, para 19,13\% na dose $80 \mathrm{t} \mathrm{ha}^{-1}$. Embora as quantidades acumuladas de $\mathrm{C}-\mathrm{CO}_{2}$ tenham aumentado em função da dose do BLP aplicada (Figura 2B), tais aumentos não foram suficientes para manter inalterada a taxa de degradação, uma vez que esta é calculada em relação ao total de carbono adicionado via dose do resíduo. Esse comportamento é consistente com outros resultados da literatura (Tester et al., 1977; Mattiazzo et al., 1998; Pires et al., 2002). O aumento do conteúdo orgânico adicionado, suplantando a capacidade microbiana de degradação, seria o responsável pelo decréscimo da taxa de degradação (Wong et al., 1998). 
Os valores das taxas de degradação dos biossólidos estudados foram inferiores ao mínimo de 30 \% em 62 dias de avaliação, estabelecido pela Norma Técnica P4.230 da CETESB (CETESB, 1999) para o uso agrícola de biossólidos provenientes do tratamento de esgotos industriais e mistos de esgotos industriais e domiciliares. No trabalho de Pires et al. (2002) esse limite também não foi atingido em 70 dias de incubação e no trabalho de Santos et al. (2002), valores acima de $30 \%$ somente foram alcançados aos 120 dias de incubação e para um dos biossólidos estudados. Torna-se, então, evidente que o valor mínimo de degradação estabelecido pela CETESB é inadequado para biossólidos, independente da origem dos esgotos, e considerando a natureza recalcitrante dos compostos orgânicos presentes nesse tipo de resíduo.

\subsubsection{Cinética química da degradação da matéria orgânica}

O termo estabilização é freqüentemente utilizado para descrever o total de MO de um substrato, mas a MO é composta por muitos componentes, cada um variando em contribuição e taxa de decomposição e, por esse motivo, o conceito de estabilização da MO deve envolver pelo menos três níveis de avaliação: valor da constante de velocidade da reação de degradação, tamanho absoluto do compartimento mineralizável e a relação com o compartimento "ativo" durante a mineralização (Boyle \& Paul, 1989). Nesse sentido, os resultados médios de $\mathrm{C}-\mathrm{CO}_{2}$ emanado acumulado foram ajustados a equações de cinética química de primeira ordem, como uma e duas fases, denominadas monofásicas e bifásicas, respectivamente (Tabela 11). Nenhum biossólido se ajustou ao modelo de cinética com três fases. 
Tabela 11. Parâmetros de cinética química e meia-vida de degradação (T1/2) obtidos a partir do ajuste dos dados de C-degradado a equações de cinética química de primeira ordem com uma e duas fases

\begin{tabular}{|c|c|c|c|c|c|c|c|c|c|c|}
\hline \multirow[t]{2}{*}{ Biossólido $^{\mathrm{a}}$} & \multirow[t]{2}{*}{ Dose } & \multicolumn{4}{|c|}{ C-degradado $=C_{0} \cdot\left(1-\mathrm{e}^{-k . t}\right)^{b}$} & \multicolumn{5}{|c|}{$\mathrm{C}$-degradado $=\mathrm{C}_{1} \cdot\left(1-\mathrm{e}^{-\mathrm{k} 1 . \mathrm{t}}\right)+\mathrm{C}_{2} \cdot\left(1-\mathrm{e}^{-\mathrm{k} 2 . \mathrm{t}}\right)^{\mathrm{C}}$} \\
\hline & & $C_{0}$ & $\boldsymbol{k}$ & $T 1 / 2^{\mathrm{d}}$ & $r$ & $C_{1}$ & $k_{1}$ & $C_{2}$ & $k_{2}$ & $r$ \\
\hline & $\mathrm{t} \mathrm{ha}^{-1}$ & $\mathrm{mg} \mathrm{kg}^{-1}$ & $\operatorname{dia}^{-1}$ & Dias & & $\mathrm{mg} \mathrm{kg}^{-1}$ & $\operatorname{dia}^{-1}$ & $\mathrm{mg} \mathrm{kg}^{-1}$ & $\operatorname{dia}^{-1}$ & \\
\hline BAC & 40 & 2143,94 & 0,0211 & 33 & 0,988 & 745,82 & 0,0211 & 1398,65 & 0,0211 & 0,988 \\
\hline BAP & 40 & 2369,45 & 0,0744 & 9 & 0,983 & 832,20 & 0,2809 & 1959,87 & 0,0305 & 0,998 \\
\hline BAS & 40 & 2889,36 & 0,0702 & 10 & 0,994 & s/ ajuste & s/ ajuste & s/ ajuste & s/ ajuste & s/ ajuste \\
\hline BLP & 40 & 799,26 & 0,0636 & 11 & 0,973 & 362,24 & 0,2138 & 1312,81 & 0,0075 & 0,998 \\
\hline CL & 40 & 588,30 & 0,0209 & 33 & 0,993 & 54,62 & 0,5490 & 947,34 & 0,0081 & 1,00 \\
\hline BAP & 10 & 779,02 & 0,0606 & 11 & 0,970 & 284,74 & 0,2813 & 922,04 & 0,0136 & 1,00 \\
\hline BAP & 20 & 1343,80 & 0,0706 & 10 & 0,970 & 537,93 & 0,2833 & 1318,19 & 0,0185 & 0,997 \\
\hline BAP & 80 & 4646,07 & 0,0621 & 11 & 0,998 & s/ ajuste & s/ ajuste & s/ ajuste & s/ ajuste & s/ ajuste \\
\hline
\end{tabular}

a BAC = biossólido anaeróbio condicionado com cal e cloreto férrico; BAP = biossólido anaeróbio condicionado com polímero sintético; BAS = biossólido anaeróbio seco termicamente; BLP = biossólido proveniente de lagoas de estabilização e condicionado com polímero sintético; e CL = composto de lodo de esgoto obtido por compostagem em pilhas aeradas após mistura do BLP com bagaço de cana e restos de poda urbana.

${ }^{\mathrm{b}} \mathrm{C}$-degradado $=\mathrm{C}_{0} \cdot\left(1-\mathrm{e}^{-\mathrm{k} . \mathrm{t}}\right)$. Em que: C-degradado $\left(\mathrm{mg} \mathrm{kg}^{-1}\right)=$ carbono emanado como $\mathrm{CO}_{2}$ no tempo $\mathrm{t} ; \mathrm{C}_{0}\left(\mathrm{mg} \mathrm{kg}^{-1}\right)=$ carbono potencialmente mineralizável em 70 dias; $\mathrm{k}\left(\right.$ dia $\left.{ }^{-1}\right)=$ constante de velocidade da reação de degradação do carbono; e $\mathrm{t}=$ tempo em dias.

${ }^{\mathrm{c}} \mathrm{C}$-degradado $=\mathrm{C}_{1} \cdot\left(1-\mathrm{e}^{-\mathrm{k} 1 . \mathrm{t}}\right)+\mathrm{C}_{2} \cdot\left(1-\mathrm{e}^{-\mathrm{k} 2 . \mathrm{t}}\right)$. Em que: C-degradado $\left(\mathrm{mg} \mathrm{kg} \mathrm{kg}^{-1}\right)=$ carbono emanado como $\mathrm{CO}_{2}$ no tempo t; $\mathrm{C}_{1}\left(\mathrm{mg} \mathrm{kg}^{-1}\right)=$ carbono potencialmente mineralizável durante a primeira fase do processo de degradação; $\mathrm{k}_{1}\left(\mathrm{dia}^{-1}\right)=$ constante de velocidade da reação de degradação do carbono durante a primeira fase; $\mathrm{C}_{2}\left(\mathrm{mg} \mathrm{kg}^{-1}\right)=\mathrm{carbono}$ potencialmente mineralizável durante a segunda fase do processo de degradação; $\mathrm{k}_{2}=$ constante de velocidade da reação de degradação do carbono durante a segunda fase; e $\mathrm{t}=$ tempo em dias.

${ }^{\mathrm{d}} \mathrm{T} 1 / 2$ = meia-vida de degradação, calculada pela expressão: $\mathrm{T} 1 / 2=\ln 2 / \mathrm{k}$. 
Considerando os cinco biossólidos aplicados na dose de $40 \mathrm{t} \mathrm{ha}^{-1}$, três deles, BAP, BAS e BLP, tiveram valores da constante de velocidade de degradação (k) semelhantes, o que proporcionou valores de T1/2 também próximos, variando de 9 a 11 dias (Tabela 11). Os dois outros resíduos, BAC e CL, tiveram valores de k inferiores aos anteriormente citados, com correspondente valor de T1/2 igual a 33 dias. Menores valores de k ocorreram provavelmente devido ao maior grau homogeneidade da fração orgânica do CL e, no caso do BAC, devido ao impacto inicial depressivo sobre a microbiota (lag-fase), cuja duração foi de cerca de sete dias, em que as parcelas com o biossólido apresentaram quantidades de $\mathrm{C}-\mathrm{CO}_{2}$ emanadas inferiores ou semelhantes ao controle. Wiseman \& Zibilske (1988) observaram em função do tempo e temperatura de incubação, e de diferenças nas propriedades químicas de biossólidos, que num período inicial de 11 dias de incubação houve emanação média de C- $\mathrm{CO}_{2}$ correspondente a 70 \% do total medido durante todo o período de avaliação.

A aplicação do BAP nas quatro doses testadas não evidenciou alterações dos valores de $\mathrm{k}$ e, consequentemente, de $\mathrm{T} 1 / 2$, somente incrementos do $\mathrm{C}$ potencialmente mineralizável $\left(\mathrm{C}_{0}\right)$ com o aumento da dose (Tabela 11). Cabe ressaltar que a meia vida de degradação (T1/2) corresponde ao tempo necessário para que $50 \%$ do carbono potencialmente mineralizável $\left(\mathrm{C}_{0}\right)$ tenha sido emanado das mistura na forma de $\mathrm{CO}_{2}$, e não o tempo necessário para que 50 \% do total de C-orgânico adicionado via resíduo tenha sido degradado.

Com exceção do BAS, o ajuste a equação de cinética química bifásica revelou que o processo de degradação do material orgânico dos biossólidos aplicados na dose de $40 \mathrm{t} \mathrm{ha}^{-1}$ apresentou duas fases (Tabela 11). De modo geral, a primeira fase foi caracterizada por elevada velocidade de degradação de compostos orgânicos $\left(\mathrm{k}_{1}\right)$ presentes em quantidades limitadas $\left(C_{1}\right)$, cuja exaustão do substrato ocorreu em poucos dias. A segunda fase caracterizou-se pela redução da velocidade da reação de degradação $\left(\mathrm{k}_{2}\right)$, em comparação com $\mathrm{k}_{1}$, e aumento da quantidade de carbono mineralizado $\left(C_{2}\right)$. O BAC apresentou iguais valores de $k_{1}$ e $k_{2}$, reflexo provavelmente da lag-fase induzida pelo resíduo. A diferença entre as velocidades de degradação do material orgânico dos resíduos, na primeira e na segunda fases do processo, pode ser 
percebida pelos valores da relação $k_{1} / k_{2}$. Esses valores foram de 0,13 , 28 e 67, respectivamente para os biossólidos BAC, BAP, BAS, BLP e CL, sendo indicativo de quantas vezes a velocidade da primeira fase foi superior a da segunda fase. Os biossólidos BLP e CL apresentaram os maiores contrastes entre as velocidades da reação de degradação. A duração da primeira fase de degradação, determinada graficamente a partir das equações bifásicas e dos parâmetros de cinética mostrados na Tabela 11, foi de 20 dias para o BAC, 5 dias para o BAP, 7 dias para o BLP e, apenas, 2 dias para o CL. De modo geral, a primeira fase de degradação foi responsável por 20 a $35 \%$ do total de C-orgânico degradado em 70 dias de incubação.

O conjunto de parâmetros e informações obtidas a partir do ajuste dos dados às equações de cinética química permite afirmar que o BLP e o CL possuem MO mais estabilizada, em comparação aos demais biossólidos, apresentando ainda restrita quantidade de compostos prontamente degradáveis pela microbiota do solo.

As doses do biossólido BAP não influenciaram os valores de $\mathrm{k}_{1} \mathrm{e} \mathrm{k}_{2}$, somente de carbono emanado em cada fase $\left(\mathrm{C}_{1}\right.$ e $\left.\mathrm{C}_{2}\right)$, à semelhança do ocorrido na equação monofásica. Na maior dose do BAP não foi possível o ajuste ao modelo bifásico. A duração da primeira fase de degradação também não foi alterada em função das doses, variando de 5 a 6 dias.

\subsubsection{Relação entre degradação e composição química da matéria orgânica dos biossólidos}

Na Tabela 12 são apresentados os valores médios dos índices testados para previsão da degradação da MO dos biossólidos após aplicação no solo. Exceto para a relação C-médio/N, os valores dos índices variaram entre os biossólidos. As relações entre as frações de carbono orgânico e o teor total de N, bem como a razão de carbono oxidável (RCO), são tentativas na previsão da degradação ou em correlações com os parâmetros de cinética química. Justifica-se o uso desses índices em função do período restrito de avaliação, em que há, supostamente, uma seqüência de decomposição dos compostos orgânicos presentes no resíduo, como ocorre com materiais vegetais 
(Brady \& Weil, 2002), no sentido de consumo primeiro dos lábeis, evoluindo para os menos lábeis com o aumento do tempo de incubação.

Tabela 12. Valores dos índices de qualidade da matéria orgânica, testados como preditores da taxa de degradação dos biossólidos. Médias ( \pm desvio padrão) de quatro repetições

\begin{tabular}{ccccccccc}
\hline Bioss. $^{\mathbf{a}}$ & $\mathbf{C} / \mathbf{N}$ & C-lábil / N & C-médio / N & C-resistente/N & Lign. / N & ILC $^{\mathbf{b}}$ & RCO $^{\mathbf{c}}$ & $\mathbf{Q H L}^{\mathbf{d}}$ \\
\hline \multirow{2}{*}{ BAC } & 7,50 & 2,73 & 2,57 & 2,20 & 0,61 & 0,38 & 1,42 & 0,90 \\
& $( \pm 0,20)$ & $( \pm 0,14)$ & $( \pm 0,27)$ & $( \pm 0,37)$ & $( \pm 0,22)$ & $( \pm 0,11)$ & $( \pm 0,08)$ & $( \pm 0,03)$ \\
& 7,34 & 1,98 & 2,10 & 3,09 & 4,58 & 0,86 & 1,76 & 0,42 \\
BAP & $( \pm 0,38)$ & $( \pm 0,08)$ & $( \pm 0,26)$ & $( \pm 0,21)$ & $( \pm 0,23)$ & $( \pm 0,04)$ & $( \pm 0,10)$ & $( \pm 0,06)$ \\
& 7,91 & 2,48 & 1,74 & 3,69 & 3,15 & 0,70 & 1,89 & 0,50 \\
BAS & $( \pm 0,17)$ & $( \pm 0,16)$ & $( \pm 0,41)$ & $( \pm 0,41)$ & $( \pm 0,49)$ & $( \pm 0,10)$ & $( \pm 0,17)$ & $( \pm 0,10)$ \\
& 11,10 & 4,82 & 2,39 & 4,14 & 7,06 & 0,52 & 1,58 & 0,52 \\
BLP & $( \pm 0,46)$ & $( \pm 0,14)$ & $( \pm 0,41)$ & $( \pm 0,29)$ & $( \pm 1,22)$ & $( \pm 0,07)$ & $( \pm 0,06)$ & $( \pm 0,07)$ \\
& 11,99 & 7,05 & 1,89 & 3,05 & 5,41 & 0,36 & 1,34 & 0,66 \\
CL & $( \pm 0,44)$ & $( \pm 0,42)$ & $( \pm 0,71)$ & $( \pm 0,32)$ & $( \pm 0,33)$ & $( \pm 0,02)$ & $( \pm 0,06)$ & $( \pm 0,02)$
\end{tabular}

\footnotetext{
${ }^{a}$ BAC = biossólido anaeróbio condicionado com cal e cloreto férrico; BAP = biossólido anaeróbio condicionado com polímero sintético; BAS = biossólido anaeróbio seco termicamente; BLP = biossólido proveniente de lagoas de estabilização e condicionado com polímero sintético; e CL = composto de lodo de esgoto obtido por compostagem em pilhas aeradas após mistura do BLP com bagaço de cana e restos de poda urbana.

${ }^{\mathrm{b}}$ ILC = índice lignocelulósico, calculado: lignina / (lignina + celulose);

${ }^{\mathrm{c}} \mathrm{RCO}=$ razão de carbono oxidável, calculado: C-orgânico / C-Walkley \& Black;

${ }^{\mathrm{d}} \mathrm{QHL}=$ quociente holocelulose : lignocelulose, calculado: (hemicelulose + celulose) / (hemicelulose + celulose + lignina).
}

Os valores da relação $\mathrm{C} / \mathrm{N}$ para todos os biossólidos podem ser considerados baixos (Tabela 12), o que seria indicativo de rápida mineralização da MO dos biossólidos após aplicação no solo (Brady \& Weil, 2002). No entanto, em função das taxas de degradação dos resíduos, bem como de outros resultados encontrados na literatura, discutidos no item 3.3.1.2, nota-se que a fração predominante da MO dos biossólidos é constituída de compostos orgânicos recalcitrantes. Ao invés de indicar rápida degradação no solo, valores de relação $\mathrm{C} / \mathrm{N}$ da inferiores a 12 podem ser reflexo 
da predominância de uma MO parcialmente decomposta (Levi-Minzi et al., 1986; Bernal et al., 1998a), o que parece ser mais condizente para biossólidos, considerando-se a natureza dos mesmos.

Os índices Lignina/N (Bubb et al., 1998; Jamaludheen \& Kumar; 1999); ILC (Melillo et al., 1982; Feigl et al., 1995) e QHL (Cortez et al., 1996) são normalmente utilizados para avaliação da qualidade de materiais de origem vegetal. Eles relacionam compostos orgânicos que reconhecidamente possuem diferentes graus de biodegradabilidade. A razão Lignina/N relaciona um composto recalcitrante, a lignina, com o $\mathrm{N}$, predominantemente contido em aminoácidos e proteínas, portanto, de fácil degradação no solo. O índice lignocelulósico (ILC) novamente incorpora a lignina, e relaciona com o conteúdo de celulose, mais facilmente degradada pela microbiota em comparação ao primeiro composto orgânico. O quociente holocelulose:lignocelulose, adiciona, em relação ao ILC, a hemicelulose. De modo simplificado, quanto menor os valores da razão Lignina/N e do ILC, maior seria decomposição da MO do resíduo no ambiente, enquanto que para o QHL a relação com a degradação da MO é positiva, isto é, quanto maior o valor do QHL, maior seria a degradação da MO.

Apenas três dos índices correlacionaram significativamente ( $\leq 5 \%$ de probabilidade) com a taxa de degradação dos biossólidos após 70 dias de incubação (Tabela 13). Como esperado, a relação $\mathrm{C} / \mathrm{N}(\mathrm{r}=-0,987)$ e a relação C-lábil/N ( $\mathrm{r}=$ -0,935), correlacionaram negativamente com a taxa de degradação. O terceiro índice significativamente correlacionado com a taxa de degradação foi obtido a partir dos resultados das determinações de hemicelulose, celulose e lignina nos biossólidos. A correlação entre QHL e taxa de degradação foi positiva e apresentou valor de r igual a 0,950. Considerando que o QHL difere de outro índice testado, o ILC, por adicionar a hemicelulose, pode-se afirmar que o conteúdo de hemicelulose nos resíduos é parâmetro importante na estimativa da degradação dos mesmos após aplicação no solo. Isso é confirmado observando-se na Tabela 13 o valor de r e o nível de significância (Prob. > t) da correlação entre o teor de hemicelulose e a taxa de degradação. A correlação entre o teor de hemicelulose na massa seca do resíduo e a taxa de degradação foi negativa ( $\mathrm{r}=$ $-0,975)$, bem como entre o teor de tanino e a taxa de degradação ( $r=-0,877)$. A celulose 
(base seca) também foi correlacionada significativamente com a taxa de degradação dos biossólidos (Tabela 13) e apresentou comportamento inverso ao esperado, isto é, correlação positiva com a degradação $(r=0,975)$.

Tabela 13. Valores de coeficiente de correlação (r) e nível de significância (Prob. > t) das correlações simples entre os parâmetros de caracterização da fração orgânica, expressos em relação ao total de massa seca, e as taxas de degradação ao final de 70 dias de incubação

\begin{tabular}{lcclcc}
\hline Parâmetro & r & Prob. > t & Parâmetro & r & Prob. > t \\
\hline MO-total & $-0,000$ & 0,9875 & C-lábil / N & $-0,935$ & 0,0196 \\
C-total & 0,141 & 0,8203 & C-médio / N & 0,032 & 0,9521 \\
C-orgânico & 0,031 & 0,9514 & C-resistente / N & $-0,410$ & 0,4935 \\
C-inorgânico & 0,464 & 0,4309 & Açúcares & 0,182 & 0,7708 \\
C-solúvel & 0,675 & 0,2116 & Proteína Bruta & 0,567 & 0,3194 \\
N-total & 0,528 & 0,3601 & Lipídeos & 0,647 & 0,2376 \\
N-orgânico & 0,567 & 0,3192 & Hemicelulose & $-0,975$ & 0,0047 \\
N-inorgânico & 0,126 & 0,8377 & Celulose & 0,975 & 0,0047 \\
P-total & 0,784 & 0,1161 & Lignina & $-0,217$ & 0,7261 \\
P-orgânico & 0,672 & 0,2142 & Fenóis & $-0,837$ & 0,0769 \\
P-inorgânico & 0,599 & 0,2857 & Taninos & $-0,877$ & 0,0507 \\
C-lábil & $-0,780$ & 0,1196 & Lignina /N & $-0,780$ & 0,1193 \\
C-médio & 0,523 & 0,3652 & ILC ${ }^{\text {a }}$ & 0,000 & 1,0000 \\
C-resistente & 0,303 & 0,6187 & RCO ${ }^{b}$ & 0,629 & 0,2557 \\
C/N & $-0,987$ & 0,0018 & QHL ${ }^{c}$ & 0,950 & 0,0134 \\
\hline${ }^{a}$ ILC = índice lignocelulósico, calculado: lignina / (lignina + celulose); & \\
${ }^{b}$ RCO = razão de carbono oxidável, calculado: C-orgânico / C-Walkley \& Black; & & \\
${ }^{\mathrm{c}}$ QHL = quociente holocelulose : lignocelulose, calculado: (hemicelulose + celulose) / (hemicelulose + celulose + lignina).
\end{tabular}

Quando a concentração de celulose foi expressa como porcentagem do total de MO do resíduo, a correlação foi negativa com a taxa de degradação, enquanto a correlação da taxa com a hemicelulose foi positiva (Tabela 14), apesar desta última não ter sido significativa a $5 \%$ de probabilidade. Tais resultados são coerentes com o que se espera em função da natureza da hemicelulose e celulose, sendo o primeiro composto 
mais facilmente degradado pela microbiota edáfica do que o segundo (Brady \& Weil, 2002). Os teores dos compostos, expressos em relação ao total de MO, não têm a interferência do conteúdo orgânico de cada resíduo, ou seja, representam a composição química do material orgânico presente e são indicativo da qualidade desse material. Por esse motivo, os compostos expressos como porcentagem do total de MO (ou C-orgânico) devem correlacionar melhor com a taxa de degradação dos resíduos, até mesmo porque a taxa de degradação é calculada em relação ao carbono adicionado via dose do biossólido. Hattori \& Mukai (1986) também encontraram melhores correlações entre os compostos orgânicos expressos em relação ao total de MO de biossólidos e as taxas de degradação, em comparação a utilização dos resultados expressos em relação a massa seca dos resíduos.

Outros compostos expressos em relação a $\mathrm{MO}$ total e correlacionados significativamente com a taxa de degradação foram: proteína bruta $(\mathrm{r}=0,999)$, fenóis $(\mathrm{r}=-0,969)$ e taninos $(\mathrm{r}=-0,956)$. Compostos orgânicos nitrogenados, como aminoácidos e proteínas, representam fontes potenciais de carbono e nitrogênio devido a abundância na MO dos biossólidos (Tabela 9) e a baixa relação C/N (Lerch et al., 1992). Além disso, microrganismos proteolíticos são ubíquos em solos e biossólidos (Hankin \& Hill, 1978; Loll \& Bollag, 1983), confirmando a importância das proteínas como substrato para a atividade microbiana. No caso de fenóis e taninos, freqüentemente solúveis em água, estes podem formar complexos altamente resistentes com proteínas durante a decomposição de resíduos, resultando em redução das taxas de mineralização do carbono e do nitrogênio (Sauvesty et al., 1992; Brady \& Weil, 2002).

As variáveis C-solúvel em água e C-lábil, expressas como porcentagem do total de C-orgânico dos biossólidos, também foram correlacionadas significativamente com as taxas de degradação (Tabela 14). A correlação com C-solúvel foi positiva ( $\mathrm{r}=$ 0,935), enquanto com o C-lábil foi negativa $(\mathrm{r}=-0,889)$. Quantidades de compostos orgânicos facilmente degradáveis pela microbiota edáfica podem induzir uma situação de anaerobiose passageira, pelo consumo intenso de $\mathrm{O}_{2}$ e liberação de $\mathrm{CO}_{2}$, que atrasaria o processo de mineralização da $\mathrm{MO}$, justificando relações inversas entre teores desses compostos e taxas de degradação de resíduos orgânicos. Os teores de C-solúvel em água 
foram cerca de 25 a 250 vezes menores que os teores de C-lábil dos resíduos, e seriam responsáveis por 2,96 a 6,35 \% do total de C-emanado acumulado em 70 dias de incubação dos biossólidos. Essas quantidades de C-solúvel seriam insuficientes para sustentar, sequer, a primeira fase de degradação (item 3.3.2.3). Desse modo, pode-se supor que o C-solúvel em água não estaria presente nos resíduos em quantidade suficiente para causar efeito depressivo na taxa de degradação da MO, enquanto que as quantidades de carbono na fração lábil teriam induzido tal efeito. Situação semelhante em solo tratado com biossólido é reportada por Wong et al. (1998), porém nesse trabalho os autores citam a redução da concentração de $\mathrm{O}_{2}$ no solo, causada pela umidade excessiva do resíduo aplicado, como provável explicação para menores taxas de degradação com as doses testadas.

Tabela 14. Valores de coeficiente de correlação (r) e nível de significância (Prob. > t) das correlações simples entre os parâmetros de caracterização da fração orgânica, expressos como porcentagem do total de MO ou C-orgânico, e as taxas de degradação dos biossólidos ao final de 70 dias de incubação

\begin{tabular}{|c|c|c|c|c|c|}
\hline Parâmetro & $\mathbf{r}$ & Prob. $>t$ & Parâmetro & $\mathbf{r}$ & Prob. $>t$ \\
\hline C-solúvel $^{\text {a }}$ & 0,935 & 0,0198 & Lipídeos ${ }^{b}$ & 0,850 & 0,0681 \\
\hline C-lábil ${ }^{\text {a }}$ & $-0,889$ & 0,0434 & Hemicelulose ${ }^{\mathrm{b}}$ & 0,812 & 0,0950 \\
\hline C-médio ${ }^{\mathrm{a}}$ & 0,744 & 0,1492 & Celulose $^{\mathrm{b}}$ & $-0,971$ & 0,0059 \\
\hline C-resistente ${ }^{a}$ & 0,612 & 0,2732 & Lignina $^{\text {b }}$ & $-0,410$ & 0,4937 \\
\hline Açúcares b & 0,285 & 0,6417 & Fenóis $^{b}$ & $-0,969$ & 0,0066 \\
\hline Proteína Bruta ${ }^{b}$ & 0,999 & 0,0000 & Taninos $^{\mathrm{b}}$ & $-0,956$ & 0,0109 \\
\hline
\end{tabular}

A correlação do teor de proteína bruta, em porcentagem da MO, com a taxa de degradação dos resíduos apresentou o maior valor de r $(0,999)$ e nível de significância extremamente baixo $\left(<10^{-4}\right)$. Adicionalmente, as quantidades de proteína bruta adicionadas via biossólidos seriam suficientemente elevadas (Tabela 8) para explicar, sozinhas, as diferenças na degradação da MO dos resíduos. Em função desses resultados, bem como da facilidade de quantificação dos teores de MO e de proteína 
bruta, esta última, expressa em relação ao conteúdo orgânico, deve ser considerada variável promissora para fins de previsão da degradação de biossólidos pós-aplicação no solo. As correlações significativas de dois índices que incorporam o teor total de $\mathrm{N}$ (relação C/N e C-lábil/N), apresentados na Tabela 13, confirmam a importância dos compostos orgânicos nitrogenados no processo de degradação da fração orgânica dos resíduos.

Com as equações de cinética de primeira ordem monofásicas (Tabela 11) foram estimadas as quantidades de carbono degradado após 2, 3, 5, 10, 15, 20, 30, 45 e 70 dias de incubação e calculadas as taxas de degradação nessas épocas, para os biossólidos aplicados em dose correspondente a $40 \mathrm{t} \mathrm{ha}^{-1}$. As taxas foram, então, correlacionadas com o teor inicial de proteína nos resíduos (Tabela 9), gerando os dados apresentados na Figura 3.

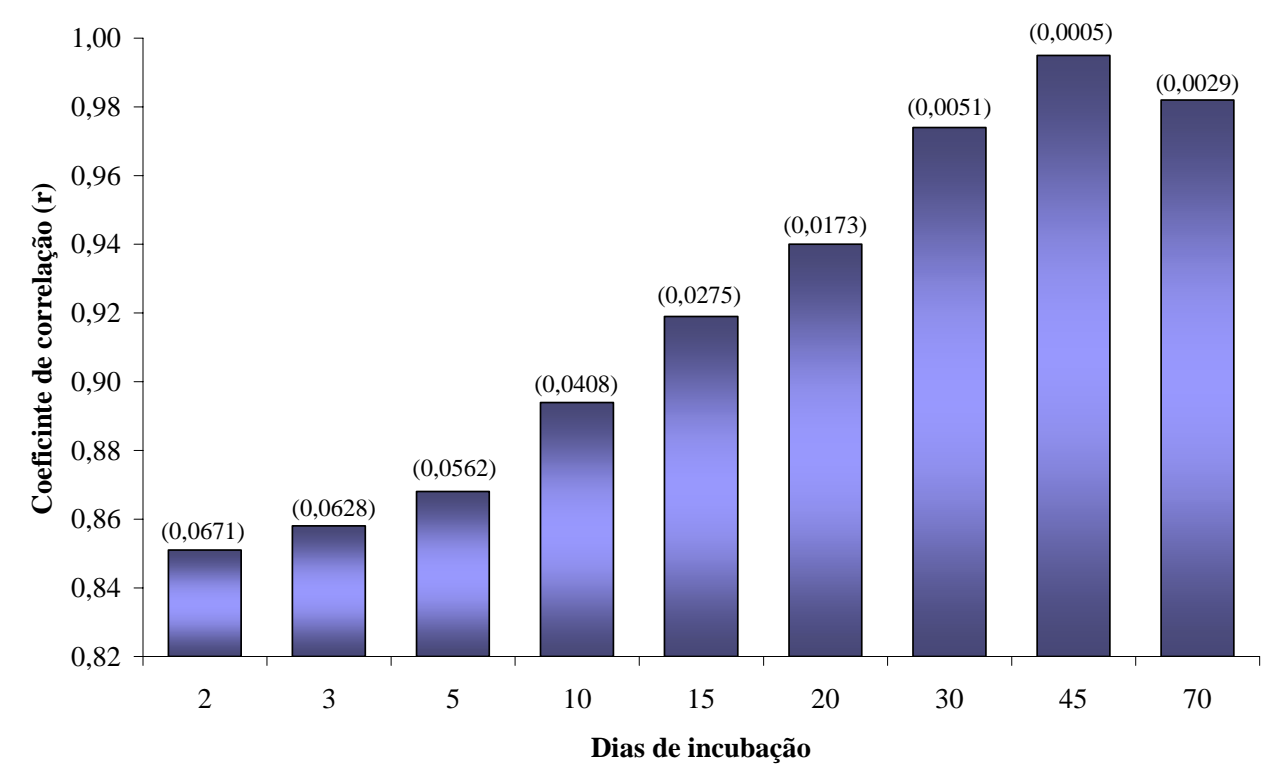

Figura 3 - Valores de coeficiente de correlação (r) obtidos em correlações estatísticas entre as taxas de degradação dos biossólidos (após 2, 3, 5, 10, 15, 20, 30, 45 e 70 dias de incubação) e o teor inicial de proteína na matéria orgânica dos resíduos. Valores entre parênteses indicam a Prob $>t$ 
Pela análise da Figura 3, pode-se observar que os valores de $\mathrm{r}$ aumentaram com o tempo de incubação das amostras, sendo indicativo da crescente participação do carbono contido no pool protéico como substrato para o metabolismo microbiano (Lerch et al., 1992). O suprimento de carbono e energia para o metabolismo microbiano no início da incubação, provavelmente, contou com maior participação relativa de outros compostos de carbono mais lábeis.

Na Tabela 15 são apresentadas as equações matemáticas para estimar a taxa de degradação de biossólidos, em função dos parâmetros correlacionados significativamente ( $\leq 5 \%$ de probabilidade).

Tabela 15. Equações matemáticas para previsão das taxa de degradação (y) dos biossólidos aplicados na dose de $40 \mathrm{t} \mathrm{ha}^{-1}$

\begin{tabular}{lcclcc}
\hline Parâmetro (x) & \multicolumn{2}{c}{ Equação (y = a + b . x) } & \multicolumn{2}{c}{ Parâmetro (x) } & \multicolumn{2}{c}{ Equação (y = a + b x) } \\
& $\boldsymbol{a}$ & $\boldsymbol{b}$ & & $\boldsymbol{a}$ & $\boldsymbol{b}$ \\
\hline C/N & 50,22 & $-3,79$ & C-solúvel $^{\mathrm{b}}$ & 0,57 & 20,16 \\
C-lábil / N $^{\text {a }}$ & 29,77 & $-3,75$ & Fração lábil $^{\text {b }}$ & 39,63 & $-0,61$ \\
Hemicelulose $^{\text {a }}$ & 25,29 & $-0,12$ & Celulose $^{c}$ & 24,90 & $-0,53$ \\
Celulose $^{\text {a }}$ & 25,29 & $-0,12$ & Fenóis $^{c}$ & 34,67 & $-399,65$ \\
Taninos $^{\text {a }}$ & 28,02 & $-101,09$ & Taninos $^{c}$ & 31,15 & 602,56 \\
QHL & $-10,13$ & 36,81 & Proteína Bruta $^{c}$ & $-19,76$ & 0,98 \\
\hline
\end{tabular}

${ }^{\mathrm{a}}$ Valor em $\mathrm{g} \mathrm{kg}^{-1}$ de massa seca do biossólido;

${ }^{\text {b }}$ Valor em porcentagem do total de C-orgânico;

${ }^{\mathrm{c}}$ Valor em porcentagem do total de MO.

Para melhor compreender a dinâmica do carbono adicionado via biossólido ao solo e sua relação com a composição química inicial da fração orgânica dos resíduos, foram feitas correlações de alguns parâmetros de qualidade da MO dos biossólidos (Tabelas 6, 7 e 9), com os valores das constantes de velocidade da primeira $\left(k_{1}\right)$ e segunda $\left(\mathrm{k}_{2}\right)$ fases da reação de degradação bifásica (Tabela 11). Somente foram utilizados os dados médios referentes aos biossólidos BAC, BAP, BLP e CL, uma vez que o BAS não se ajustou ao modelo de cinética com duas fases. Os resultados das correlações com k k $_{1}$ e k são mostrados nas Tabelas 16 e 17, respectivamente. 
Tabela 16. Valores de coeficiente de correlação (r) e nível de significância (Prob. > t) das correlações simples entre alguns parâmetros de caracterização da matéria orgânica (MO) dos biossólidos e as constantes de velocidade da primeira fase da reação de degradação da $\mathrm{MO}\left(\mathrm{k}_{1}\right)$

\begin{tabular}{|c|c|c|c|c|c|}
\hline Parâmetro & $\mathbf{r}$ & Prob. $>t$ & Parâmetro & $\overline{\mathbf{R}}$ & Prob. $>t$ \\
\hline C-solúvel ${ }^{\text {a }}$ & $-0,810$ & 0,1898 & Lipídeos $^{\text {b }}$ & $-0,707$ & 0,2925 \\
\hline C-lábil a & 0,947 & 0,0525 & Hemicelulose ${ }^{b}$ & $-0,782$ & 0,2175 \\
\hline C-médio a & $-0,613$ & 0,3867 & Celulose $^{\mathrm{b}}$ & 0,732 & 0,2682 \\
\hline C-resistente ${ }^{a}$ & $-0,948$ & 0,0518 & Lignina $^{\text {b }}$ & 0,498 & 0,5019 \\
\hline Açúcares b & $-0,659$ & 0,3410 & Fenóis ${ }^{b}$ & 0,609 & 0,3907 \\
\hline Proteína Bruta ${ }^{\text {b }}$ & $-0,691$ & 0,3085 & Taninos ${ }^{b}$ & 0,718 & 0,2815 \\
\hline
\end{tabular}

Tabela 17. Valores de coeficiente de correlação (r) e nível de significância (Prob. > t) das correlações simples entre alguns parâmetros de caracterização da matéria orgânica (MO) dos biossólidos e as constantes de velocidade da segunda fase da reação de degradação da $\mathrm{MO}\left(\mathrm{k}_{2}\right)$

\begin{tabular}{|c|c|c|c|c|c|}
\hline Parâmetro & $\mathbf{r}$ & Prob. $>t$ & Parâmetro & $\overline{\mathbf{R}}$ & Prob. $>t$ \\
\hline C-solúvel $^{\text {a }}$ & 0,849 & 0,1507 & Lipídeos $^{b}$ & 0,926 & 0,0736 \\
\hline C-lábil ${ }^{a}$ & $-0,663$ & 0,3367 & Hemicelulose ${ }^{\mathrm{b}}$ & 0,706 & 0,2937 \\
\hline C-médio a & 0,954 & 0,0460 & Celulose $^{\mathrm{b}}$ & $-0,912$ & 0,0874 \\
\hline C-resistente ${ }^{a}$ & 0,108 & 0,8924 & Lignina $^{\text {b }}$ & $-0,108$ & 0,8920 \\
\hline Açúcares b & $-0,335$ & 0,6645 & Fenóis ${ }^{b}$ & $-0,938$ & 0,0621 \\
\hline Proteína Bruta b & 0,914 & 0,0859 & Taninos ${ }^{b}$ & $-0,808$ & 0,1918 \\
\hline
\end{tabular}


Nenhum dos compostos orgânicos, nem o carbono solúvel em água correlacionaram significativamente com as constantes $k_{1}$ (Tabela 16) e $k_{2}$ (Tabela 17). As frações de C-lábil e C-resistente foram correlacionadas com os valores de $k_{1}$ (Tabela 16), enquanto a fração C-médio com os valores de $k_{2}$ (Tabela 17). A fração resistente foi correlacionada negativamente com velocidade da reação de degradação da primeira fase $(r=-0,948)$ e a fração lábil foi correlacionada positivamente $(r=0,947)$. Isso significa que maiores proporções de carbono na fração lábil corresponderam a aumentos da velocidade de reação da primeira fase, enquanto a maior participação do carbono da fração resistente no total de C-orgânico, determinaram menores velocidades da reação da primeira fase. Na segunda fase de degradação, a fração média correlacionou positivamente com a velocidade da reação, indicando que o carbono presente nessa fração é determinante na magnitude dessa fase, responsável 65 a 80 \% total de carbono emanado acumulado no período avaliado. A correlação positiva da fração C-médio com a taxa de degradação, aliada a crescente participação do pool protéico como substrato para o metabolismo microbiano, com a seqüência do tempo de incubação, sugerem que parte expressiva dos compostos nitrogenados fizeram parte da fração C-médio. De certa forma a correlação positiva $(\mathrm{r}=0,918)$ entre o C-médio (base seca) e o teor de proteína bruta (base seca) reforça tal suposição (Apêndice 1).

Quanto ao método de fracionamento do C-orgânico, os resultados foram coerentes ao que se propõe; isto é, separar por meio de artifícios exclusivamente químicos, frações de C-orgânico com diferenças em termos de acessibilidade aos microrganismos (Lefroy et al., 1993; Blair et al., 1995; Blair et al., 1998; Chan et al., 2001).

\subsection{Conclusões}

A matéria orgânica (MO) dos biossólidos é constituída, predominantemente, por compostos recalcitrantes. Após aplicação no solo, a taxa de degradação dependente da intensidade dos processos biológicos para estabilização da MO, à que são submetidos os resíduos nas estações de tratamento de esgotos. O processo de degradação ocorreu em duas etapas; uma primeira, intensa e de curta duração (média de 8 dias), onde compostos 
mais lábeis de carbono foram exauridos, e uma segunda etapa, menos intensa e responsável por mais de 65 \% do total de carbono orgânico degradado durante o período de 70 dias avaliação. Dentre os compostos orgânicos determinados, as proteínas representaram importante fração da MO dos biossólidos, correlacionando-se melhor com a taxa de degradação ao final do período de avaliação e sendo, por isso, promissoras como variável preditora da taxa de degradação de biossólidos após aplicação no solo. A participação do compartimento protéico no processo de degradação da $\mathrm{MO}$ foi crescente com o tempo de incubação, indicando que no início do período, outros compostos mais lábeis de carbono funcionaram como fonte de $\mathrm{C}$ e de energia para a microbiota edáfica. 


\section{ESTOQUE DE CARBONO E QUALIDADE DA MATÉRIA ORGÂNICA DE UM LATOSSOLO TRATADO COM BIOSSÓLIDO E SOB CULTIVO DE EUCALIPTO}

\section{Resumo}

O objetivo do estudo foi determinar o efeito da aplicação de doses de um biossólido alcalino nos estoques de $\mathrm{C}$ e N, bem como na qualidade da matéria orgânica (composição química e efeito na CTC) de um Latossolo cultivado com eucalipto, após cinco anos da aplicação do resíduo. O trabalho foi desenvolvido em área de campo pertencente a Estação Experimental da ESALQ/USP, no município de Itatinga, Estado de São Paulo. Em março de 1998, após corte de uma plantação de Eucalyptus grandis com sete anos de idade e novo plantio, com a mesma espécie, no sistema de cultivo mínimo, foi iniciado o experimento. Quatro meses depois foi realizada a aplicação do biossólido digerido anaeróbio $\left(\mathrm{pH}=10,6\right.$; C-orgânico $=165,12 \mathrm{~g} \mathrm{~kg}^{-1} ; \mathrm{N}$-total = 15,34 $\mathrm{g} \mathrm{kg}^{-1} ; \quad$ P-total $=10,6 \mathrm{~g} \mathrm{~kg}^{-1} ; \mathrm{K}=1,23 \mathrm{~g} \mathrm{~kg}^{-1}$ ), com umidade original, sobre a superfície do solo e nas entrelinhas da cultura, sem posterior incorporação. Cinco tratamentos foram avaliados: (i) Controle; (ii) Fertilização Mineral com N, P, K, B e Zn (Fert. Mineral) ; (iii) $10 \mathrm{t} \mathrm{ha}^{-1}$ de biossólido $+\mathrm{K}\left(10 \mathrm{t} \mathrm{ha}^{-1}\right)$; (iv) $20 \mathrm{t} \mathrm{ha}^{-1}$ de biossólido

+ K (20 t ha $\left.{ }^{-1}\right)$; e (v) $40 \mathrm{t} \mathrm{ha}^{-1}$ de biossólido + K (40 $\left.\mathrm{t} \mathrm{ha}^{-1}\right)$. Foram coletadas amostras de solo (0-5, 5-10, 10-20, 20-30 e 30-60 cm) dos tratamentos, cinco anos após a aplicação do biossólido, para as determinações previstas. Para todas as profundidades foram determinados os teores totais de $\mathrm{C}$ e $\mathrm{N}$ e a densidade aparente. Nas amostras coletadas até $20 \mathrm{~cm}$ de profundidade, foram feitas determinações de $\mathrm{pH}$, frações de $\mathrm{C}$ orgânico por graus de oxidação, teores de alguns compostos orgânicos (açúcares solúveis, proteína bruta, lipídeos, hemicelulose, celulose e lignina), CTC a pH 7,0 e CTC ao pH natural. 
Após cinco anos da aplicação do biossólido, não foram observadas diferenças entre os tratamentos, para os teores totais e estoques de $\mathrm{C}$ e $\mathrm{N}$, densidade e frações do carbono orgânico. Os estoques médios de C e N, até $60 \mathrm{~cm}$ de profundidade, foram iguais a 92,86 e 4,41 $\mathrm{t} \mathrm{ha}^{-1}$, respectivamente. Cerca de $50 \%$ do total de C esteve no compartimento denominado lábil, comportamento típico de áreas com espécies e/ou manejo que favorecem o retorno de resíduos vegetais ao solo. Dos compostos orgânicos determinados, somente a lignina mostrou alteração em função dos tratamentos. Os tratamentos $40 \mathrm{t} \mathrm{ha}^{-1}$ de biossólido e Fert. Mineral apresentaram a MO do solo $(0-5 \mathrm{~cm})$ mais enriquecida com lignina, em comparação aos demais, sendo esse efeito atribuído a maior deposição de folhas nesses dois tratamentos e a natureza recalcitrante da lignina. Os resultados de CTC confirmaram que a quantidade e qualidade da MO do solo, após cinco anos da aplicação de biossólido ou fertilizantes minerais, não foi alterada, pelo menos no que se refere a esta propriedade. A CTC (pH natural) mostrou-se mais dependente dos valores $\mathrm{pH}$ do solo, do que dos teores de $\mathrm{C}$, sendo que os primeiros foram influenciados pelas doses de biossólido, apresentando, de maneira geral, valores superiores aos observados no solo dos tratamentos Controle e Fert. Mineral, para as três profundidades avaliadas.

\section{CARBON STOCKS AND ORGANIC MATTER QUALITY IN AN OXISOL TREATED WITH BIOSOLID AND PLANTED WITH EUCALYPTUS}

\section{Summary}

The aim of this study was to determine the effect of biosolid application on $\mathrm{C}$ and $\mathrm{N}$ stocks, as well as the effect on organic matter quality (chemical composition and CEC) in an Oxisol planted with eucalyptus, after five years of residue application. The work was developed in an area of the Experimental Station of ESALQ/USP, in the municipal district of Itatinga, São Paulo State. In March 1998, the experiment was initiated after cutting off a Eucalyptus grandis plantation of seven years of age and a new plantation with the same species, in the minimum tillage system. After four months the anaerobic digested biosolid was applied $\left(\mathrm{pH}=10.6 ;\right.$ C-organic $=165.12 \mathrm{~g} \mathrm{~kg}^{-1} ; \mathrm{N}$ - 
total $=15.34 \mathrm{~g} \mathrm{~kg}^{-1} ;$ P-total $=10.6 \mathrm{~g} \mathrm{~kg}^{-1} ; \mathrm{K}=1.23 \mathrm{~g} \mathrm{kg-1}$ ), with original humidity, on the surface soil between the plant rows, without incorporation. Five treatments were evaluated: (i) Control; (ii) Mineral Fertilization with N, P, K, B and Zn (Mineral Fert.); (iii) $10 \mathrm{t} \mathrm{ha}^{-1}$ of biosolid + K (10 t ha $\left.{ }^{-1}\right)$; (iv) $20 \mathrm{t} \mathrm{ha}^{-1}$ of biosolid $+\mathrm{K}\left(20 \mathrm{t} \mathrm{ha}^{-1}\right)$; and (v) $40 \mathrm{t} \mathrm{ha}^{-1}$ of biosolid $+\mathrm{K}\left(40 \mathrm{t} \mathrm{ha}^{-1}\right)$. Soil samples were taken $0-5,5-10,10-20,20-30$ and 30-60 cm soil depths, about five years after application of the biosolid or mineral fertilizer, for the expected determinations. Total amounts of $\mathrm{C}$ and $\mathrm{N}$ and bulk density were determined in all samples. In the samples collected up to $20 \mathrm{~cm}$ of depth, were made $\mathrm{pH}$ determinations, oxidizible organic carbon fractions, amounts of some organic compounds (soluble sugars, crude protein, lipids, hemicellulose, cellulose and lignin), CEC the $\mathrm{pH} \mathrm{7,0} \mathrm{and} \mathrm{CEC} \mathrm{to} \mathrm{the} \mathrm{natural} \mathrm{pH}$. After five years of the biosolid application, differences were not observed between treatments, for the total amounts and stocks of $\mathrm{C}$ and $\mathrm{N}$, bulk density and oxidizible organic carbon fractions. Mean $\mathrm{C}$ and $\mathrm{N}$ stocks, up to $60 \mathrm{~cm}$ of depth, were the same to 92.86 and $4.41 \mathrm{t} \mathrm{ha}^{-1}$, respectively. About $50 \%$ of the total $\mathrm{C}$ was in the fraction denominated labile, typical behavior of areas with species and/or handling that enables the return of plant residues to the soil. From the determined organic compounds, only the lignin content was different between the treatments. The treatments $40 \mathrm{t} \mathrm{ha}^{-1}$ of biosolid and Mineral Fert. presented on soil OM (0-5 cm depth) more enriched with lignin. This is attributed to largest deposition of leaves in these two treatments and the recalcitrant nature of the lignin. The CEC (natural $\mathrm{pH}$ ) values were more dependent on soil $\mathrm{pH}$, than on the soil C content. The doses of biosolid influenced the soil $\mathrm{pH}$ values, for the three depths sampled. 


\subsection{Introdução}

Aplicações de biossólidos em plantios florestais de rápido crescimento, como fonte de nutrientes para as árvores e/ou como condicionador de solos, é prática comum em países como EUA, Nova Zelândia e Austrália (Estados Unidos, 1984; Polglase \& Mayers, 1995; Magesan \& Wang, 2003), porém no Brasil, ainda é incipiente. O uso de biossólidos em áreas de exploração florestal, com espécies visando a produção de madeira, celulose e papel, é citada como prática ambientalmente segura, devido ao reduzido risco de entrada de metais pesados na cadeia alimentar (Santos et al., 1997; Andrade \& Mattiazzo, 2000). Adicionalmente, deve-se considerar que biossólidos podem melhorar a fertilidade de solos florestais (Vaz \& Gonçalves, 2002, Rocha, 2002; Soares, 2003), geralmente muito intemperizados e originados de materiais pobres quimicamente, que lhe conferem baixa capacidade de troca catiônica (CTC) e restrita disponibilidade de nutrientes (Gonçalves et al., 1987).

Aplicações de biossólidos a solos agrícolas têm, potencialmente, a capacidade de afetar a dinâmica da matéria orgânica (MO), com conseqüências no estoque de carbono (C) do solo, função de alterações no teor do elemento (Boyle \& Paul, 1989; Melo et al., 1994; Iakimenko et al., 1996; Oliveira et al., 2002 ; Vaz \& Gonçalves, 2002; Simonete et al., 2003) e/ou na densidade aparente do solo tratado (Terry et al., 1979a; Metzger \& Yaron, 1987; Metzger et al., 1987; Jorge et al., 1991; Marciano, 1999). O aumento do estoque de $\mathrm{C}$ do solo, pode estar associado a benefícios agronômicos, como aumento da CTC, à depender da qualidade da MO adicionada e de sua transformação no solo (Oliveira et al., 2002), mas, independente disso, implica em alternativa para mitigação do aquecimento global ou efeito estufa, pelo seqüestro de C no solo (Gibson et al., 2002).

Discussões acerca do seqüestro de $\mathrm{C}$ no solo, como alternativa para mitigação do aquecimento global, passam obrigatoriamente pelo Protocolo de Kyoto, documento internacional em processo de ratificação. Nesse documento, dentre as inúmeras resoluções e comprometimentos de cada parte envolvida, está descrito o chamado "Clean Development Mechanism" (CDM), o qual tem por finalidade implementar ações conjuntas entre países que devem obrigatoriamente limitar ou reduzir 
a emissão de gases do efeito estufa (países do Anexo I) e países que não possuem tal comprometimento (países do não-Anexo I). Segundo o CDM, países do Anexo I subsidiariam atividades de projetos certificados em países do não-Anexo I para seqüestro do $C$ atmosférico, visando abater o montante de $C$ seqüestrado, de suas metas de emissão. Nesse sentido, uma das alternativas especuladas atualmente relaciona-se ao seqüestro de $C$ no solo por meio do uso agrícola de biossólidos (Gibson et al., 2002). Tal possibilidade teria reflexos na captação de recursos internacionais, por países em desenvolvimento (não-Anexo I), os quais poderiam implementar planos de saneamento básico, uma vez que biossólidos somente são gerados no tratamento dos esgotos. $\mathrm{O}$ Protocolo de Kyoto ainda não reconhece o seqüestro de $C$ no solo como medida mitigadora do aquecimento global, porém esse reconhecimento deve ocorrer concomitante ao desenvolvimento de pesquisas e ferramentas certificadoras dessa atividade. No caso do uso agrícola de biossólidos, informações a esse respeito ainda são escassas na literatura. O seqüestro de C em reflorestamentos já está previsto no Protocolo de Kyoto.

Considerando que espécies florestais são citadas como preferenciais para receber aplicações de biossólidos (Santos et al., 1997; Andrade \& Mattiazzo, 2000) ; que áreas de produção florestal apresentam potencial para seqüestrar carbono no solo e nas árvores (Gibson et al., 2002); e, finalmente, que solos florestais são muito intemperizados (Gonçalves et al., 1987) e, como tal, exibem CTC altamente dependente da MO (Brady \& Weill, 2002); o presente estudo foi realizado. O objetivo do estudo foi verificar o efeito da aplicação de doses de um biossólido alcalino nos teores e estoques de $\mathrm{C}$ e de $\mathrm{N}$, bem como na qualidade da MO (composição química e efeito na CTC) de um Latossolo cultivado com eucalipto, após cinco anos da aplicação do resíduo. As informações aqui reunidas deverão servir para delinear novas pesquisas e auxiliar na interpretação dos resultados obtidos em outros estudos desenvolvidos no mesmo local deste trabalho. 


\subsection{Material e Métodos}

\subsubsection{Local de estudo}

O estudo de caso foi conduzido em área de campo pertencente à Estação Experimental da ESALQ/USP no município de Itatinga, SP $\left(22^{\circ} 59^{\prime}\right.$ Sul e $48^{\circ} 41^{\prime}$ Oeste), cerca de $220 \mathrm{~km}$ da cidade de São Paulo, SP.

As condições edafoclimáticas e florísticas da área experimental são representativas de extensos blocos de florestas homogêneas plantadas no planalto paulista e o solo foi classificado como LATOSSOLO VERMELHO-AMARELO distrófico de textura média (Tabelas 18 e 19). O clima é, segundo classificação de Köppen, mesotérmico de inverno seco, com temperatura média do mês mais frio (julho) inferior a $18^{\circ} \mathrm{C}$ e do mês mais quente (janeiro) superior a $22^{\circ} \mathrm{C}$. A precipitação média anual é de 1300 mm e o total de chuvas no mês mais seco não ultrapassa 30 mm.

Tabela 18. Características químicas do solo da área experimental

\begin{tabular}{|c|c|c|c|c|c|c|c|c|c|c|c|c|}
\hline Prof. & $\mathbf{p H}_{\mathrm{CaCl} 2}$ & MO & $\mathbf{P}$ & $\mathbf{K}$ & $\mathrm{Ca}$ & Mg & $\overline{\mathrm{H}+\mathrm{Al}}$ & Al & SB & CTC & V\% & $\mathbf{m} \%$ \\
\hline $\mathrm{cm}$ & & $\mathrm{g} \mathrm{dm}^{-3}$ & $\mathrm{mg} \mathrm{dm}$ & --- & 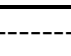 & - & $-\mathrm{mmc}$ & $\mathrm{dm}$ & 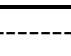 & $\overline{----}$ & & \\
\hline $0-30$ & 4,0 & 16 & 1 & 1,2 & 1 & 1 & 34,4 & 7 & 3 & 37 & 9 & 69 \\
\hline $30-60$ & 4,0 & 15 & 1 & 0,5 & 1 & 1 & 31,0 & 6 & 3 & 34 & 7 & 71 \\
\hline $60-90$ & 4,1 & 14 & 1 & 0,3 & 1 & 1 & 28,0 & 5 & 2 & 30 & 8 & 68 \\
\hline
\end{tabular}

Tabela 19. Granulometria e teores totais de óxidos de ferro, alumínio e silício do solo da área experimental

\begin{tabular}{|c|c|c|c|c|c|c|c|}
\hline Prof. & Argila & Areia grossa & Areia fina & Silte & $\mathrm{Fe}_{2} \mathrm{O}_{3}$ & $\mathbf{A l}_{2} \mathbf{O}_{3}$ & $\mathrm{SiO}_{2}$ \\
\hline $\mathrm{cm}$ & & . & & $\mathrm{g}^{-1}$ & & & 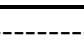 \\
\hline $0-30$ & 168 & 532 & 241 & 59 & 25,0 & 64,0 & 45,0 \\
\hline $30-60$ & 190 & 495 & 266 & 49 & 27,4 & 64,0 & 47,0 \\
\hline 60-90 & 197 & 496 & 278 & 29 & 28,8 & 76,0 & 48,0 \\
\hline
\end{tabular}

Adaptado de Andrade (1999). 


\subsubsection{Detalhes do experimento}

No ano de 1998, um convênio firmado entre o Departamento de Ciências Florestais da ESALQ/USP, o Instituto de Pesquisas e Estudos Florestais (IPEF) e a Companhia de Saneamento Básico do Estado de São Paulo (SABESP), iniciou, pioneiramente no Brasil, um experimento de campo com aplicação de doses de um biossólido alcalino em área cultivada com Eucalyptus grandis. Esse estudo vêm sendo conduzido, desde então, com pesquisas em diversas linhas do conhecimento: (i) fertilidade do solo, nutrição, crescimento e produção das árvores (Vaz, 2000; Martins, 2002; Rocha, 2002); (ii) ciclagem de nutrientes (Poggiani et al., 2000; Guedes \& Poggiani, 2003); (iii) fitodisponibilidade e lixiviação de nitrogênio e metais pesados (Andrade \& Mattiazzo, 2000; Velasco-Molina \& Mattiazzo, 2003); (iv) microbiologia do solo (Fortes Neto, 2000); (v) viabilidade econômica (Faria, 2000; Faria \& Rodriguez, 2000); e (vi) impacto sobre a fauna silvestre. Embora o projeto tenha caráter multidisciplinar, a MO do solo tratado com doses do resíduo somente foi parte integrante das avaliações de fertilidade do solo, sendo pouco individualizada nos estudos.

O biossólido utilizado foi proveniente da ETE-Barueri (SABESP), que trata de parte dos esgotos da grande São Paulo, na época, por meio do processo de lodos ativados convencionais com aeração por ar difuso e digestão anaeróbia dos lodos primários e secundários, com posterior estabilização química do resíduo com cal hidratada e cloreto férrico. Algumas características químicas (Andrade \& Mattiazzo, 2000) do biossólido utilizado foram: $\mathrm{pH}_{\text {água }}=10,6$; Umidade $\left(65^{\circ} \mathrm{C}\right)=615,2 \mathrm{~g} \mathrm{~kg}^{-1}$; C-orgânico $=165,12 \mathrm{~g} \mathrm{~kg}^{-1} ; \quad \mathrm{N}$-total $=15,34 \mathrm{~g} \mathrm{~kg}^{-1} ; \quad$ P-total $=10,6 \mathrm{~g} \mathrm{~kg}^{-1} ; \mathrm{K}=$ $1,23 \mathrm{~g} \mathrm{~kg}^{-1} ; \mathrm{Ca}=149,95 \mathrm{~g} \mathrm{~kg}^{-1} ;$ e $\mathrm{Mg}=3,76 \mathrm{~g} \mathrm{~kg}^{-1}$.

A instalação do experimento foi realizada em março de 1998, após corte raso de uma plantação de Eucalyptus grandis com sete anos de idade e novo plantio (3 x 2 m) com a mesma espécie. O plantio foi realizado na entrelinha da antiga plantação, no sistema de cultivo mínimo. Em julho de 1998 foi realizada a aplicação do biossólido, com umidade original, nas entrelinhas da cultura. Nove tratamentos foram distribuídos aleatoriamente em cada um dos quatro blocos locados no campo, num total de 36 
parcelas experimentais. Cada parcela $(20$ x $30 \mathrm{~m})$ foi constituída de 100 plantas, 10 linhas com 10 plantas cada, sendo que a área útil compreendeu as 36 plantas centrais. Detalhes sobre a implantação e condução inicial do experimento podem ser encontradas em Poggiani et al. (2000).

Dos nove tratamentos instalados na área experimental, apenas cinco foram avaliados neste trabalho: (i) Controle; (ii) Fertilização Mineral (Fert. Mineral) ; (iii) $10 \mathrm{t} \mathrm{ha}^{-1}$ de biossólido + complementação com K (10 t ha $\left.{ }^{-1}\right)$; (iv) $20 \mathrm{t} \mathrm{ha}^{-1}$ de biossólido + complementação com K (20 t ha $\left.{ }^{-1}\right)$; e (v) $40 \mathrm{t} \mathrm{ha}^{-1}$ de biossólido + complementação com K (40 t ha ${ }^{-1}$ ). O tratamento Fert. Mineral constou da aplicação de 1,5 t ha ${ }^{-1}$ de calcário dolomítico (a lanço em área total), $127 \mathrm{~kg} \mathrm{ha}^{-1}$ de $\mathrm{N}, 60 \mathrm{~kg} \mathrm{ha}^{-1}$ de $\mathrm{P}, 137 \mathrm{~kg} \mathrm{ha}^{-1}$ de $\mathrm{K}, 1,3 \mathrm{~kg} \mathrm{ha}^{-1}$ de B e 2,0 $\mathrm{kg} \mathrm{ha}^{-1}$ de $\mathrm{Zn}$, parcelados durante o primeiro ano de crescimento do eucalipto. As complementações com $\mathrm{K}$ nos tratamentos que receberam biossólido foram realizadas no primeiro ano de crescimento do eucalipto, de modo a atingir $137 \mathrm{~kg} \mathrm{ha}^{-1}$ de $\mathrm{K}$, levando-se em consideração as quantidades do nutriente fornecidas via doses do biossólido.

\subsubsection{Amostragem do solo e análises químicas}

O solo (0-5, 5-10, 10-20, 20-30 e 30-60 cm) foi amostrado em setembro de 2003, cerca de cinco anos após a aplicação do biossólido. Amostras simples foram coletadas em número de cinco por parcela, tomadas nas entrelinhas da cultura, misturadas e homogeneizadas para obtenção de uma amostra composta representativa da unidade experimental. Também foram feitas coletas de amostras indeformadas de solo para obtenção da densidade aparente.

As amostras de solo foram secas ao ar, homogeneizadas e passadas em peneira $2 \mathrm{~mm}$. Em todas as amostras coletadas foram determinados os teores totais de C e N. Nas amostras até $20 \mathrm{~cm}$ foram determinados também: valores de $\mathrm{pH}$ em $\mathrm{CaCl}_{2}$, frações do C-orgânico em função de diferentes graus de oxidação, teores de alguns compostos orgânicos (açúcares solúveis, proteína bruta, lipídeos, hemicelulose, celulose e lignina), valores de CTC ao pH 7,0 ( $\left.\mathrm{CTC}_{7}\right)$ e de CTC ao pH natural (CTC efetiva$_{\text {) }}$.

Na seqüência são apresentados os métodos de análise utilizados. 


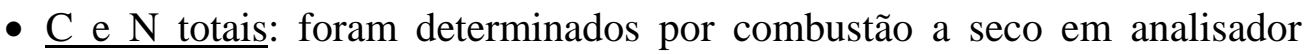
LECO CN-2000, usando amostras dos biossólidos moídas e peneiradas a 100 meshes;

- Fracionamento do C-orgânico por graus de oxidação: foi adaptado de Chan et al. (2001), cujo fundamento se baseia na oxidação do C-orgânico das amostras por combustão seca e também úmida $\left(\mathrm{K}_{2} \mathrm{Cr}_{2} \mathrm{O}_{7}\right)$ em meio ácido, neste último caso com duas concentrações de $\mathrm{H}_{2} \mathrm{SO}_{4}$, 12 e $6 \mathrm{~mol} \mathrm{~L}^{-1}$. O procedimento adotado permitiu a obtenção de três frações de C-orgânico:

- C-lábil (6 mol L $\left.\mathbf{L}^{-1} \mathrm{H}_{2} \mathrm{SO}_{4}\right)$ : C-orgânico oxidado por $\mathrm{K}_{2} \mathrm{Cr}_{2} \mathrm{O}_{7}$ em meio ácido de 6 mol L ${ }^{-1}$ de $\mathrm{H}_{2} \mathrm{SO}_{4}$;

- C-médio (12 - $\left.6 \mathrm{~mol} \mathrm{~L}^{-1} \mathrm{H}_{2} \mathrm{SO}_{4}\right)$ : diferença entre o C-orgânico oxidado por

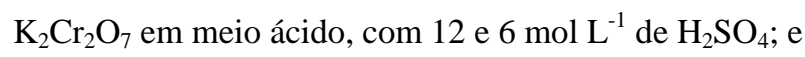

- C-resistente (C-total - $12 \mathrm{~mol} \mathrm{~L}^{-1} \mathrm{H}_{2} \mathrm{SO}_{4}$ ): C-orgânico residual obtido pela diferença entre a oxidação com $\mathrm{K}_{2} \mathrm{Cr}_{2} \mathrm{O}_{7}$ em meio ácido de $12 \mathrm{~mol} \mathrm{~L}^{-1}$ de $\mathrm{H}_{2} \mathrm{SO}_{4}$, e o total de C obtido por combustão seca (LECO CN-2000).

- $\underline{\mathrm{pH}} \underline{\mathrm{CaCl}}_{\mathrm{C} 2}$ : foi determinado em extrato aquoso com relação solo:solução igual a 1:2,5. A solução utilizada foi de $\mathrm{CaCl}_{2} 0,01 \mathrm{~mol} \mathrm{~L}^{-1}$.

- Compostos orgânicos: foram determinados por meio de seqüências complexas de digestões e extrações, originalmente desenvolvidas para análises de forrageiras e madeira. Os teores de lipídeos (extrato etéreo) e proteína bruta (PB) foram determinados conforme recomendação da Association of Official Analytical Chemists (1995), enquanto os carboidratos, a celulose, a hemicelulose e a lignina foram quantificados conforme descrito em Van Soest \& Wine (1967).

- $\underline{\mathrm{CTC}}_{7}$ : a CTC potencial a pH 7,0 foi determinada por meio de metodologia adaptada de Glória et al. (1975), usando o $\mathrm{NH}_{4}{ }^{+}$como cátion índice, fornecido via solução de acetato de amônio $\left(\mathrm{CH}_{3} \mathrm{COONH}_{4} ; \mathrm{pH}=7,0\right)$. O deslocamento do $\mathrm{NH}_{4}{ }^{+}$foi por meio de troca iônica com Ca ${ }^{+2}$, fornecido via solução de acetato de cálcio $\left(\mathrm{Ca}\left(\mathrm{CH}_{3} \mathrm{COO}\right)_{2}, \mathrm{pH}=7,0\right)$. 
A determinação do $\mathrm{NH}_{4}{ }^{+}$foi realizada por destilação da amostra em meio alcalino, recebimento do $\mathrm{NH}_{3}$ em ácido bórico, e posterior titulação com solução ácida padronizada (Mulvaney, 1996).

- $\underline{\mathrm{CTC}}_{\text {efetiva }}:$ a CTC efetiva (pH natural) foi determinada por meio de metodologia adaptada de Glória et al. (1975), usando o $\mathrm{K}^{+}$como cátion índice, fornecido via solução de $\mathrm{KCl} 1,0 \mathrm{~mol} \mathrm{~L}{ }^{-1}$. O deslocamento do $\mathrm{K}^{+}$ foi por meio de troca iônica com $\mathrm{Ca}^{+2}$, fornecido via solução de $\mathrm{CaCl}_{2}$ $0,5 \mathrm{~mol} \mathrm{~L}^{-1}$. A determinação do $\mathrm{K}^{+}$no extrato foi realizada em fotometria de emissão de chama.

\subsubsection{Forma de análise dos resultados}

Os resultados dos teores totais de $\mathrm{C}$ e $\mathrm{N}$ foram utilizados, juntamente com a densidade aparente, para o cálculo dos estoques de $\mathrm{C}$ e $\mathrm{N}$ no solo, nas cinco camadas amostradas, e até 20 e $60 \mathrm{~cm}$ de profundidade.

As frações de carbono orgânico (C-resistente, C-médio e C-lábil) foram interpretadas em termos de concentração na massa seca de solo e em relação ao total de MO. De forma semelhante, os teores de açúcares solúveis, proteína bruta, lipídeos, hemicelulose, celulose e lignina foram expressos em relação a massa seca de solo e em relação ao total de MO das amostras. A MO das amostras foi estimada multiplicando-se o teor total de C pelo fator 1,72 (58\% de C na MO). Os resultados expressos em relação ao conteúdo orgânico tiveram como objetivo evidenciar melhor possíveis alterações na composição química da MO do solo, excluindo o efeito da concentração de carbono (ou MO) na amostra.

A estatística aplicada a todas as variáveis avaliadas foi a análise de variância, seguida de teste para comparação das médias (Tukey 5\%), tendo como fatores de variação os Blocos (4) e os Tratamentos (5). Os resultados de CTC foram utilizados em correlações estatísticas com o teor total de C no solo e frações de C-orgânico, bem como com os valores de $\mathrm{pH}$, este último somente com a $\mathrm{CTC}_{\text {efetiva. }}$ 


\subsection{Resultados e discussão}

\subsubsection{Teores de carbono e nitrogênio no solo}

Após cinco anos da aplicação do biossólido ou dos fertilizantes minerais, o teor total de C no solo (Tabela 20), não diferiu entre os tratamentos, para as cinco profundidades avaliadas até $60 \mathrm{~cm}$.

Tabela 20. Teores totais de carbono nas camadas do solo amostradas até $60 \mathrm{~cm}$ de profundidade, cinco anos após a aplicação de biossólido (10, 20 e 40 t ha $\left.{ }^{-1}\right)$ ou de fertilizantes minerais, em área sob cultivo de eucalipto

\begin{tabular}{|c|c|c|c|c|c|}
\hline \multirow[t]{2}{*}{ Tratamento } & \multicolumn{5}{|c|}{ Carbono $\left(\mathrm{g} \mathrm{kg}^{-1}\right)$} \\
\hline & $0-5 \mathrm{~cm}$ & $5-10 \mathrm{~cm}$ & $10-20 \mathrm{~cm}$ & $20-30 \mathrm{~cm}$ & $30-60 \mathrm{~cm}$ \\
\hline Controle & $48,90 \mathrm{a}^{(1)}$ & 11,42 a & 10,18 a & $9,27 \mathrm{a}$ & $7,62 \mathrm{a}$ \\
\hline Fert. Mineral & 44,33 a & 9,79 a & 9,76 a & 8,75 a & 7,49 a \\
\hline $10 \mathrm{t} \mathrm{ha}^{-1}$ & $50,61 \mathrm{a}$ & 12,87 a & $10,24 \mathrm{a}$ & 9,15 a & $6,94 \mathrm{a}$ \\
\hline $20 \mathrm{t} \mathrm{ha}^{-1}$ & 47,33 a & 10,96 a & 11,05 a & 9,32 a & $7,41 \mathrm{a}$ \\
\hline $40 \mathrm{t} \mathrm{ha}^{-1}$ & $41,71 \mathrm{a}$ & 12,33 a & $10,32 \mathrm{a}$ & $8,88 \mathrm{a}$ & $6,80 \mathrm{a}$ \\
\hline Média & 46,58 & 11,48 & 10,31 & 9,08 & 7,25 \\
\hline$C V \%$ & 29,93 & 21,28 & 15,37 & 9,96 & 9,68 \\
\hline
\end{tabular}

O monitoramento da fertilidade do solo, durante o primeiro ano após a aplicação do biossólido revelou, aos seis meses, redução dos teores de MO (ou C) na camada superficial de 0-5 cm de profundidade, nos tratamentos que receberam doses de biossólido de 20 e $40 \mathrm{t} \mathrm{ha}^{-1}$, em comparação ao Controle e ao tratamento Fert. Mineral (Vaz \& Gonçalves, 2002). A redução do teor de C nos tratamentos 20 e $40 \mathrm{t} \mathrm{ha}^{-1}$, em relação ao Controle, foi correspondente a $30 \%$. A aplicação de $10 \mathrm{t} \mathrm{ha}^{-1}$ de biossólido proporcionou, nessa mesma época e camada do solo, o maior teor de $\mathrm{C}$, superando os demais tratamentos citados. Após treze meses, os teores de C $(0-5 \mathrm{~cm})$ nos tratamentos com 20 e $40 \mathrm{t} \mathrm{ha}^{-1}$ de biossólido foram semelhantes aos observados no Controle e Fert. Mineral, com destaque novamente para o tratamento $10 \mathrm{tha}^{-1}$, com o maior o teor médio (Vaz \& Gonçalves, 2002). Aos trinta e dois meses da aplicação das doses do resíduo, nenhuma diferença foi observada entre os tratamentos (Rocha, 2002). Nas três épocas 
citadas e considerando somente as camadas 5-10 e 10-20 cm, não foram observadas alterações do C do solo em função dos tratamentos testados, embora aos 32 meses da aplicação, Rocha (2002) tenha destacado uma certa tendência de elevação desses teores no solo tratado com biossólido, o que não foi confirmada com os resultados aqui apresentados. A redução inicial dos teores de C do solo foi atribuída a ocorrência do chamado "priming effect" ou efeito priming (Vaz \& Gonçalves, 2002). No cenário avaliado, o efeito priming teria sido provocado pelo aumento da atividade microbiana, função da presença de compostos facilmente biodegradáveis na MO do biossólido, que após exaustão, em relativo curto período, induziu a degradação da MO original do solo, como forma de manutenção da elevada atividade microbiana e tendo em vista que a maior proporção da MO do biossólido é recalcitrante (Gerzabek et al., 2001). É premissa básica para caracterização do efeito priming, que o processo seja de curta duração e imediatamente após a intervenção no sistema (Kuzyakov et al., 2000), o que concorda com a descrição dos acontecimentos. Soares (2003), estudando uma área com eucalipto e tratada com biossólido digerido anaeróbio, também encontrou redução dos teores de MO (ou C) no solo, aos sete e dose meses após aplicação do resíduo em doses até $40 \mathrm{tha}^{-1}$, atribuindo tal comportamento a ocorrência do efeito priming. No mesmo trabalho, em área adjacente e onde a camada fértil de 0-20 cm do solo foi removida, para simulação de uma área degradada, foi observado incremento do teor de C no solo devido a adição do biossólido. A explicação dada pelo autor traça um paralelo entre a existência de frações lábeis de C no solo da área não-degradada, em contraposição a predominância de compostos orgânicos mais estabilizados e/ou protegidos fisicamente na área degradada, cuja camada superficial foi removida. Na área degradada, a comunidade microbiana edáfica, estimulada pelo biossólido, após exaurir os compostos facilmente biodegradáveis do resíduo, teve pouco acesso a MO original do solo e/ou inabilidade em degradá-la, função da ocorrência da MO em micronichos protegidos fisicamente e/ou da maior estabilização da MO quando comparada a camada 0-20 da área não-degradada (Soares, 2003).

Em relação a magnitude dos valores médios de $C$ no solo $(0-5 \mathrm{~cm})$, após cinco anos, o teor médio na área foi igual a 46,58 $\mathrm{g} \mathrm{kg}^{-1}$, semelhante aos valores médios 
dos mesmos tratamentos aos trinta e dois meses da aplicação (Rocha, 2002). A recuperação dos tratamentos 20 e $40 \mathrm{t} \mathrm{ha}^{-1}$ de biossólido, em relação ao decréscimo inicial do teor de $\mathrm{C}$ na camada $0-5 \mathrm{~cm}$ do solo deve ter ocorrido pela maior deposição de folhas, em comparação ao Controle. No período compreendido entre os 17 e 28 meses de desenvolvimento das árvores, o correspondente a 13 e 24 meses da aplicação do biossólido, houve deposição de 2,0 ; 3,4; 3,2 e 4,7 t ha ${ }^{-1}$ (base seca) de folhas nos tratamentos controle, Fert. Mineral, $20 \mathrm{t} \mathrm{ha}^{-1}$ e $40 \mathrm{t} \mathrm{ha}^{-1}$ de biossólido, respectivamente (Guedes, 2000).

Oliveira et al. (2002) verificaram aumentos do teor de C-orgânico em solo cultivado com cana-de-açúcar e tratado com biossólido em dois anos consecutivos, com doses acumuladas (primeiro + segundo ano) entre 70 e $211 \mathrm{t} \mathrm{ha}^{-1}$ (base seca), incorporadas a camada $0-20 \mathrm{~cm}$. Os autores observaram também que os aumentos de C-orgânico foram maiores no segundo ano, indicando a possibilidade de incrementos crescentes com sucessivas aplicações do resíduo. Deve-se ponderar, no entanto, que a simples prática de incorporação ou não do biossólido, afeta os resultados de C no solo. Quando não há incorporação do resíduo, a amostra de solo para análise é praticamente livre de partículas de biossólido, enquanto que o contrário ocorre quando o material é incorporado, isto é, partículas do resíduo encontram-se presentes no material amostrado. A determinação do teor de $\mathrm{C}$ na amostra, mesmo que por procedimentos menos drásticos de oxidação, como o método clássico de Walkley \& Black (1934), é capaz de recuperar parte expressiva do C-orgânico de biossólidos, entre 55 e 70 \% (Andrade et al., 2003) e, com isso, o C do resíduo é computado no teor da amostra. A MO de biossólidos, sujeita intensiva digestão aeróbica e anaeróbia nas estações de tratamento, é relativamente recalcitrante, promovendo, rapidamente, incrementos no teor de C-orgânico de solos tratados sucessivamente com esse tipo de resíduo, o que é explicado pela baixa taxa de degradação do material orgânico adicionado, em comparação a outros resíduos como estercos animais e adubos verdes (Saviozzi et al., 1999; Gerzabek et al., 2001).

Com relação aos teores totais de $\mathrm{N}$ no solo, não houve diferença entre os tratamentos, nas cinco camadas amostradas até $60 \mathrm{~cm}$ de profundidade (Tabela 21). Resultados anteriores do teor total de $\mathrm{N}$, até $90 \mathrm{~cm}$ de profundidade, não revelaram 
diferenças entre o Controle e os tratamentos 10, 20 e $40 \mathrm{t} \mathrm{ha}^{-1}$, aos doze meses de avaliação (Andrade \& Mattiazzo, 2000). Durante o mesmo período (Andrade \& Mattiazzo, 2000), e também após cinco anos da aplicação do biossólido (Velasco-Molina \& Mattiazzo, 2003), não foram observadas alterações do teor de $\mathrm{N}$ inorgânico no solo, em função dos tratamentos testados. Apesar das análises de solo até o momento não terem evidenciado mudanças no status edáfico de $\mathrm{N}$, a avaliação das concentrações foliares tem mostrado aumento da disponibilidade do nutriente com a dose do resíduo aplicada (Andrade \& Mattiazzo, 2000; Rocha, 2002; Guedes \& Poggiani, 2003). As concentrações totais de $\mathrm{N}$ no solo, reportadas por Andrade \& Mattiazzo (2000), doze meses após a aplicação do biossólido, foram em média 0,64 ; 0,$47 ; 0,41 ; 0,37$; e $0,31 \mathrm{~g} \mathrm{~kg}^{-1}$ para as camadas 0-10, 10-20, 20-30, 30-60 e 60-90 cm, respectivamente. Comparando-se os resultados de Andrade \& Mattiazzo (2000), com os obtidos após cinco anos da aplicação do resíduo (Tabela 21), nas camadas 10-20, 20-30 e 30-60 cm, nota-se que existe uma tendência de enriquecimento do solo em $\mathrm{N}$, que pode ser explicada em função de três principais fatores: (i) redução inicial do teor de $\mathrm{N}$ no solo, pela mineralização do $\mathrm{N}$ contido na $\mathrm{MO}$ do solo, sujeito a perdas por erosão e lixiviação, aliado ao baixo aporte de resíduos vegetais devido ao corte raso e novo plantio em fase inicial de crescimento; (ii) elevada demanda por $\mathrm{N}$ até o fechamento das copas do plantio florestal, cerca de 24 meses, reduzindo posteriormente, quando a competição por luz e por água passa a ser mais limitante ao metabolismo foliar (Gonçalves et al., 2000; Rocha, 2002); (iii) aumento da deposição de folhas após o fechamento das copas, iniciando, de fato, a ciclagem bioquímica e biogeoquímica dos nutrientes (Wadt \& Novais, 1997).

Após cinco anos da aplicação do biossólido, os valores de relação $\mathrm{C} / \mathrm{N}$ da MO do solo não diferiram em função dos tratamentos (Tabela 22). Os valores médios da relação $\mathrm{C} / \mathrm{N}$ variaram entre 22 , na camada $0-5 \mathrm{~cm}$, e 15 , na camada $10-20 \mathrm{~cm}$. A MO da camada superficial de solos geralmente apresenta relação $\mathrm{C} / \mathrm{N}$ de 10 a 12, porém solos florestais podem ter valores mais elevados (Stevenson, 1994), determinados pela deposição mais ou menos constante de material vegetal sobre o solo e pela qualidade da serrapilheira com relação C/N da ordem de 49 (Soares, 2003). 
Tabela 21. Teores totais de nitrogênio nas camadas do solo amostradas até $60 \mathrm{~cm}$ de profundidade, cinco anos após a aplicação de biossólido (10, 20 e $40 \mathrm{t} \mathrm{ha}^{-1}$ ) ou de fertilizantes minerais, em área sob cultivo de eucalipto

\begin{tabular}{|c|c|c|c|c|c|}
\hline \multirow[t]{2}{*}{ Tratamento } & \multicolumn{5}{|c|}{ Nitrogênio $\left(\mathrm{g} \mathrm{kg}^{-1}\right)$} \\
\hline & $0-5 \mathrm{~cm}$ & $5-10 \mathrm{~cm}$ & $10-20 \mathrm{~cm}$ & $20-30 \mathrm{~cm}$ & $30-60 \mathrm{~cm}$ \\
\hline Controle & $1,72 \mathrm{a}^{(1)}$ & $0,60 \mathrm{a}$ & $0,72 \mathrm{a}$ & $0,44 \mathrm{a}$ & $0,34 \mathrm{a}$ \\
\hline Fert. Mineral & $1,52 \mathrm{a}$ & $0,48 \mathrm{a}$ & 0,59 a & $0,42 \mathrm{a}$ & $0,34 \mathrm{a}$ \\
\hline $10 \mathrm{t} \mathrm{ha}^{-1}$ & 1,86 a & $0,61 \mathrm{a}$ & $0,81 \mathrm{a}$ & 0,46 a & $0,31 \mathrm{a}$ \\
\hline $20 \mathrm{t} \mathrm{ha}^{-1}$ & $1,76 \mathrm{a}$ & $0,54 \mathrm{a}$ & $0,76 \mathrm{a}$ & $0,46 \mathrm{a}$ & $0,34 \mathrm{a}$ \\
\hline $40 \mathrm{t} \mathrm{ha}^{-1}$ & $1,64 \mathrm{a}$ & $0,57 \mathrm{a}$ & $0,66 \mathrm{a}$ & $0,44 \mathrm{a}$ & $0,34 \mathrm{a}$ \\
\hline Média & 1,70 & 0,56 & 0,71 & 0,44 & 0,34 \\
\hline$C V \%$ & 24,08 & 14,32 & 29,09 & 8,47 & 9,81 \\
\hline
\end{tabular}

Tabela 22. Valores de relação C/N do solo, em diferentes camadas avaliadas até 60 cm de profundidade, cinco anos após a aplicação de biossólido (10, 20 e 40 t há $^{-1}$ ) ou de fertilizantes minerais, em área sob cultivo de eucalipto

\begin{tabular}{|c|c|c|c|c|c|}
\hline Tratamento & & & $\mathrm{C} / \mathrm{N}$ & & \\
\hline & $0-5 \mathrm{~cm}$ & $5-10 \mathrm{~cm}$ & $10-20 \mathrm{~cm}$ & $20-30 \mathrm{~cm}$ & $30-60 \mathrm{~cm}$ \\
\hline Controle & $28,49 \mathrm{a}^{(1)}$ & 19,47 a & 14,43 a & 21,12 a & $22,06 \mathrm{a}$ \\
\hline Fert. Mineral & 28,71 a & $20,57 \mathrm{a}$ & 17,31 a & 20,75 a & $22,19 \mathrm{a}$ \\
\hline $10 \mathrm{tha}^{-1}$ & 27,16 a & 21,06 a & $13,11 \mathrm{a}$ & 20,14 a & $22,20 \mathrm{a}$ \\
\hline $20 \mathrm{tha}^{-1}$ & 25,90 a & 20,66 a & 15,87 a & 20,54 a & $21,54 \mathrm{a}$ \\
\hline $40 \mathrm{t} \mathrm{ha}^{-1}$ & 25,19 a & 21,44 a & 16,29 a & 20,32 a & $20,19 a$ \\
\hline Média & 27,09 & 20,64 & 15,40 & 20,57 & 21,63 \\
\hline$C V \%$ & 7,95 & 9,59 & 27,64 & 9,46 & 6,14 \\
\hline
\end{tabular}

${ }^{(1)}$ Médias seguidas de mesma letra, em cada coluna, não diferem entre si ao nível de 5\% de probabilidade pelo teste de Tukey. 


\subsubsection{Estoques de carbono e nitrogênio no solo}

O estoque de um elemento qualquer no solo é calculado em função do teor do mesmo e da densidade do solo na camada considerada. Dessa maneira, o estoque pode ser alterado por mudança dos valores de ambas variáveis ou de somente uma delas. Como comentado anteriormente, não foi verificado efeito dos tratamentos nos teores de C (Tabela 20) e de N (Tabela 21) do solo, após cinco anos da aplicação do biossólido, ficando possíveis alterações nos estoques desses elementos, atreladas a mudanças na densidade aparente do solo, o que não foi verificado em função dos tratamentos (Tabela 23).

Marciano (1999) encontrou relação linear entre a diminuição da densidade do solo e a aplicação de doses crescentes de biossólido a um Latossolo Vermelho-Amarelo, cultivado com cana-de-açúcar. Nesse trabalho, o solo recebeu doses de 33 a $99 \mathrm{t} \mathrm{ha}^{-1}$ de biossólido, no primeiro ano da cultura, e de 37 e $112 \mathrm{t} \mathrm{ha}^{-1}$ de biossólido, no segundo ano, em ambos os casos com incorporação do resíduo a $20 \mathrm{~cm}$ de profundidade. A redução da densidade do solo somente foi verificada no segundo ano e nas camadas mais superficiais amostradas (0-5, 5-10 e 10-15 cm). Os teores de $\mathrm{C}$ no solo, nos dois anos de avaliação, aumentaram com a dose de biossólido aplicada (Oliveira et al.; 2002) e foram correlacionados com a densidade (Marciano, 1999). A redução da densidade do solo em áreas tratadas como biossólidos pode ser atribuída ao aumento do teor de C no solo, bem como ao estímulo a atividade microbiana de bactérias e fungos (Metzger et al., 1987). Outros trabalhos da literatura citam reduções da densidade do solo com a aplicação de biossólido (Terry et al., 1979a; Metzger \& Yaron, 1987; Metzger et al., 1987; Jorge et al., 1991), porém em todos eles houve incorporação do material. No presente estudo, o biossólido foi aplicado na superfície do solo, sem incorporação, e após cinco anos da aplicação do resíduo, principalmente nas doses de 20 e $40 \mathrm{t} \mathrm{ha}^{-1}$, as partículas de biossólido ainda são visualmente destacadas do solo no campo. Desse modo, pode-se supor que a maior parte das interações do biossólido com a microbiota ficou confinada a interface resíduo/solo, e portanto, o estímulo a atividade microbiana também foi, de certo modo, restringido, com menor possibilidade de alteração da densidade. Em alguns casos em que são observadas alterações da densidade do solo pela adição de biossólidos, 
é possível que o efeito seja somente devido a incorporação do resíduo, o chamado "efeito mistura", caracterizado pela mistura de um material de densidade reduzida a outro com maior densidade, resultando num valor médio, dependente da proporção entre os componentes e da diferença inicial de densidade dos materiais (Melfi \& Montes, 2001).

Os estoques de $\mathrm{C}$ e $\mathrm{N}$ no solo, acumulados até $20 \mathrm{~cm}$ e até $60 \mathrm{~cm}$ de profundidade, também não diferiram entre os tratamentos (Tabelas 26 e 27). Em média os estoques de $\mathrm{C}$ foram iguais a 48,78 e $92,86 \mathrm{t} \mathrm{ha}^{-1}$, até 20 e até $60 \mathrm{~cm}$ de profundidade, respectivamente. Nessas mesmas camadas os estoques médios de $\mathrm{N}$ foram iguais a $2,34 \mathrm{e} 4,41 \mathrm{tha}^{-1}$.

Tabela 23. Densidade aparente do solo amostrado em diferentes profundidades até $60 \mathrm{~cm}$, cinco anos após a aplicação de biossólido (10, 20 e $\left.40 \mathrm{t} \mathrm{ha}^{-1}\right)$ ou de fertilizantes minerais, em área sob cultivo de eucalipto

\begin{tabular}{|c|c|c|c|c|c|}
\hline \multirow[t]{2}{*}{ Tratamento } & \multicolumn{5}{|c|}{ Densidade $\left(\mathrm{g} \mathrm{cm}^{-3}\right)$} \\
\hline & $0-5 \mathrm{~cm}$ & $5-10 \mathrm{~cm}$ & $10-20 \mathrm{~cm}$ & $20-30 \mathrm{~cm}$ & $30-60 \mathrm{~cm}$ \\
\hline Controle & $1,11 \mathrm{a}^{(1)}$ & $1,41 \mathrm{a}$ & $1,34 \mathrm{a}$ & $1,44 \mathrm{a}$ & $1,43 \mathrm{a}$ \\
\hline Fert. Mineral & $1,14 \mathrm{a}$ & $1,38 \mathrm{a}$ & $1,38 \mathrm{a}$ & $1,37 \mathrm{a}$ & 1,42 a \\
\hline $10 \mathrm{t} \mathrm{ha}^{-1}$ & $1,12 \mathrm{a}$ & $1,41 \mathrm{a}$ & $1,45 \mathrm{a}$ & $1,45 \mathrm{a}$ & $1,44 \mathrm{a}$ \\
\hline $20 \mathrm{tha}^{-1}$ & $0,96 \mathrm{a}$ & $1,34 \mathrm{a}$ & $1,38 \mathrm{a}$ & $1,39 \mathrm{a}$ & $1,44 \mathrm{a}$ \\
\hline $40 \mathrm{tha}^{-1}$ & $1,20 \mathrm{a}$ & $1,41 \mathrm{a}$ & $1,41 \mathrm{a}$ & $1,44 \mathrm{a}$ & 1,35 a \\
\hline Média & 1,09 & 1,35 & 1,37 & 1,41 & 1,42 \\
\hline$C V \%$ & 14,89 & 13,12 & 7,69 & 7,51 & 7,64 \\
\hline
\end{tabular}

${ }^{(1)}$ Médias seguidas de mesma letra, em cada coluna, não diferem entre si ao nível de 5\% de probabilidade pelo teste de Tukey. 
Tabela 24. Estoque de carbono em cada camada de solo amostrada, até $60 \mathrm{~cm}$ de profundidade, cinco anos após a aplicação de biossólido (10, 20 e 40 t ha ${ }^{-1}$ ) ou de fertilizantes minerais, em área sob cultivo de eucalipto

\begin{tabular}{|c|c|c|c|c|c|}
\hline \multirow[t]{2}{*}{ Tratamento } & \multicolumn{5}{|c|}{ Carbono $\left(\mathrm{t} \mathrm{ha}^{-1}\right)$} \\
\hline & $0-5 \mathrm{~cm}$ & $5-10 \mathrm{~cm}$ & $10-20 \mathrm{~cm}$ & $20-30 \mathrm{~cm}$ & $30-60 \mathrm{~cm}$ \\
\hline Controle & $27,22 \mathrm{a}^{(1)}$ & 7,96 a & 10,18 a & 13,38 a & $32,58 \mathrm{a}$ \\
\hline Fert. Mineral & 28,55 a & 6,77 a & 9,76 a & 11,99 a & $31,95 \mathrm{a}$ \\
\hline $10 \mathrm{t} \mathrm{ha}^{-1}$ & 28,61 a & 9,00 a & 10,24 a & 13,28 a & 29,89 a \\
\hline $20 \mathrm{tha}^{-1}$ & 22,58 a & 7,39 a & 11,05 a & $13,01 \mathrm{a}$ & $32,16 \mathrm{a}$ \\
\hline $40 \mathrm{t} \mathrm{ha}^{-1}$ & 25,63 a & 8,70 a & 10,32 a & 12,75 a & $29,38 \mathrm{a}$ \\
\hline Média & 26,52 & 7,96 & 10,31 & 12,88 & 31,19 \\
\hline$C V \%$ & 32,75 & 20,46 & 15,37 & 12,19 & 11,60 \\
\hline
\end{tabular}

${ }^{1)}$ Médias seguidas de mesma letra, em cada coluna, não diferem entre si ao nível de 5\% de probabilidade pelo teste de Tukey.

Tabela 25. Estoque de nitrogênio em cada camada de solo amostrada, até $60 \mathrm{~cm}$ de profundidade, cinco anos após a aplicação de biossólido (10, 20 e 40 t ha $\mathrm{h}^{-1}$ ) ou de fertilizantes minerais, em área sob cultivo de eucalipto.

\begin{tabular}{|c|c|c|c|c|c|}
\hline \multirow[t]{2}{*}{ Tratamento } & \multicolumn{5}{|c|}{ Nitrogênio (t ha ${ }^{-1}$ ) } \\
\hline & $0-5 \mathrm{~cm}$ & $5-10 \mathrm{~cm}$ & $10-20 \mathrm{~cm}$ & $20-30 \mathrm{~cm}$ & $30-60 \mathrm{~cm}$ \\
\hline Controle & $0,95 \mathrm{a}^{(1)}$ & $0,41 \mathrm{a}$ & $0,96 \mathrm{a}$ & $0,64 \mathrm{a}$ & $0,34 \mathrm{a}$ \\
\hline Fert. Mineral & $0,98 \mathrm{a}$ & 0,33 a & $0,81 \mathrm{a}$ & $0,58 \mathrm{a}$ & $0,34 \mathrm{a}$ \\
\hline $10 \mathrm{tha}^{-1}$ & $1,05 \mathrm{a}$ & 0,43 a & $1,16 \mathrm{a}$ & $0,66 \mathrm{a}$ & $0,31 \mathrm{a}$ \\
\hline $20 \mathrm{t} \mathrm{ha}^{-1}$ & $0,84 \mathrm{a}$ & 0,36 a & $1,05 \mathrm{a}$ & $0,64 \mathrm{a}$ & $0,34 \mathrm{a}$ \\
\hline $40 \mathrm{t} \mathrm{ha}^{-1}$ & $1,01 \mathrm{a}$ & 0,40 a & $0,95 \mathrm{a}$ & 0,63 a & $0,34 \mathrm{a}$ \\
\hline Média & 0,97 & 0,39 & 0,99 & 0,63 & 0,34 \\
\hline$C V \%$ & 27,72 & 13,75 & 30,04 & 9,89 & 9,81 \\
\hline
\end{tabular}

${ }^{(1)}$ Médias seguidas de mesma letra, em cada coluna, não diferem entre si ao nível de 5\% de probabilidade pelo teste de Tukey. 
Tabela 26. Estoques de carbono e nitrogênio nas camadas 0 a $20 \mathrm{~cm}$ e 0 a $60 \mathrm{~cm}$ do solo, cinco anos após a aplicação de biossólido (10, 20 e $\left.40 \mathrm{t} \mathrm{ha}^{-1}\right)$ ou de fertilizantes minerais, em área sob cultivo de eucalipto

\begin{tabular}{|c|c|c|c|c|}
\hline & \multicolumn{2}{|c|}{ Carbono (t ha $\left.{ }^{-1}\right)$} & \multicolumn{2}{|c|}{ Nitrogênio (t ha $\left.{ }^{-1}\right)$} \\
\hline & $0-20 \mathrm{~cm}$ & $0-60 \mathrm{~cm}$ & $0-20 \mathrm{~cm}$ & $0-60 \mathrm{~cm}$ \\
\hline Controle & $48,57 \mathrm{a}^{(1)}$ & 94,53 a & 2,32 a & $4,44 \mathrm{a}$ \\
\hline Fert. Mineral & 48,77 a & 92,72 a & 2,13 a & $4,15 \mathrm{a}$ \\
\hline 10 t ha $^{-1}$ & 52,46 a & 95,63 a & 2,65 a & $4,66 \mathrm{a}$ \\
\hline 20 t ha $^{-1}$ & 45,16 a & 90,33 a & $2,25 \mathrm{a}$ & 4,39 a \\
\hline 40 t ha $^{-1}$ & 48,94 a & 91,08 a & 2,36 a & $4,44 \mathrm{a}$ \\
\hline Média & 48,78 & 92,86 & 2,34 & 4,41 \\
\hline$C V \%$ & 21,30 & 15,16 & 17,76 & 12,74 \\
\hline
\end{tabular}

\subsubsection{Frações do carbono orgânico do solo}

Pequenas alterações no total de $\mathrm{MO}$ ou C do solo são dificilmente detectáveis a curto prazo, devido, em parte, a variabilidade natural do solo (Lefroy et al., 1993; Blair et al., 1995). Por isso, compartimentos da MO ou do C do solo mais sensíveis ao manejo podem ser utilizados como indicadores de mudanças na dinâmica do C, como por exemplo frações de C-orgânico do solo.

Os resultados do fracionamento do $\mathrm{C}$ do solo, em função de diferentes graus de oxidação, são apresentados nas Tabelas 27 e 28. Não houve diferença entre os tratamentos para os teores de C-resistente, C-médio e C-lábil. Os teores de C-lábil nas três profundidades avaliadas responderam por cerca de 50 \% do total de $\mathrm{C}$ presente, enquanto que os teores de C-médio foram os mais baixos, variando entre 11,48 e 23,03 \% do total de C (Tabela 28). A participação do C-médio no total de C do solo aumentou com a profundidade, concomitante a redução do C-resistente. Em termos absolutos, os teores das três frações de $\mathrm{C}$ tenderam a diminuir com a profundidade (Tabela 27), o que era esperado. 
De modo geral, os resultados de pesquisas com essas frações de C evidenciam que culturas agrícolas ou sistemas de manejo que favorecem adições freqüentes de material orgânico ao solo, tendem a apresentar maior proporção de $C$ na fração lábil, em detrimento a fração resistente (Blair et al., 1995; Conteh et al., 1998; Chan et al. 2001), o que é consistente com a espécie florestal em questão e com o sistema de cultivo mínimo adotado na instalação do experimento. Em um ano de coleta, de setembro de 1999 a setembro de 2000, foram registrados valores superiores a 4,0 t de biomassa seca de folhas depositada sobre o solo, uma quantidade substancial de MO reciclada no sítio florestal (Guedes, 2000). Em áreas com pastagens na Austrália, 36 a 40 \% do total de C no solo foi encontrado presente na fração lábil (Chan et al., 2001). Espécies forrageiras apresentam elevado potencial de produção de fitomassa e, desse modo, a contribuição com carbono para o solo é intensa, principalmente por meio da renovação do sistema radicular (Koutika et al., 2000). Nas culturas de cana-de-açúcar (Blair et al., 1998) e algodão (Conteh et al., 1998), também na Austrália, em que o fogo foi utilizado no manejo, somente 14 a 18 \% do total de C do solo estava presente na fração lábil. Porém em áreas de mesmo solo e onde o fogo não foi utilizado, os valores de C-lábil foram maiores e dependentes do tempo de adoção na nova prática. 
Tabela 27. Teores carbono nas frações resistente (C-resistente), médio (C-médio) e lábil (C-lábil), nas camadas do solo amostradas até $20 \mathrm{~cm}$ de profundidade, cinco anos após a aplicação de biossólido (10, 20 e $\left.40 \mathrm{t} \mathrm{ha}^{-1}\right)$ ou de fertilizantes minerais, em área sob cultivo de eucalipto. Resultados expressos em relação a massa seca

\begin{tabular}{|c|c|c|c|}
\hline & \multicolumn{3}{|c|}{ C-resistente $\left(\mathrm{g} \mathrm{kg}^{-1}\right)$} \\
\hline & $0-5 \mathrm{~cm}$ & $5-10 \mathrm{~cm}$ & $10-20 \mathrm{~cm}$ \\
\hline Controle & $20,78 \mathrm{a}^{(1)}$ & $3,30 \mathrm{a}$ & $2,21 \mathrm{a}$ \\
\hline Fert. Mineral & 23,09 a & $3,74 \mathrm{a}$ & 3,17 a \\
\hline $10 \mathrm{t} \mathrm{ha}^{-1}$ & 22,18 a & 4,38 a & $2,70 \mathrm{a}$ \\
\hline $20 \mathrm{t} \mathrm{ha}^{-1}$ & 21,39 a & $3,56 \mathrm{a}$ & 3,86 a \\
\hline $40 \mathrm{t} \mathrm{ha}^{-1}$ & 14,86 a & $4,98 \mathrm{a}$ & $2,90 \mathrm{a}$ \\
\hline Média & 20,46 & 3,99 & 2,97 \\
\hline \multirow[t]{2}{*}{ CV\% } & 60,23 & 46,37 & 46,43 \\
\hline & \multicolumn{3}{|c|}{ C-médio ( $\mathrm{g} \mathrm{kg}^{-1}$ ) } \\
\hline Controle & 5,87 a & $2,14 \mathrm{a}$ & 2,87 a \\
\hline Fert. Mineral & $4,60 \mathrm{a}$ & $1,01 \mathrm{a}$ & 2,07 a \\
\hline $10 \mathrm{t} \mathrm{ha}^{-1}$ & $4,81 \mathrm{a}$ & 1,97 a & $2,21 \mathrm{a}$ \\
\hline 20 t ha $^{-1}$ & $4,51 \mathrm{a}$ & $2,00 \mathrm{a}$ & $2,55 \mathrm{a}$ \\
\hline $40 \mathrm{t} \mathrm{ha}^{-1}$ & 5,47 a & $2,07 \mathrm{a}$ & $2,30 \mathrm{a}$ \\
\hline Média & 5,05 & 1,84 & 2,40 \\
\hline \multirow[t]{2}{*}{$C V \%$} & 18,89 & 49,08 & 30,96 \\
\hline & \multicolumn{3}{|c|}{ C-lábil (g kg ${ }^{-1}$ ) } \\
\hline Controle & 22,24 a & 5,73 a & 5,31 a \\
\hline Fert. Mineral & 16,66 a & 5,03 a & 4,51 a \\
\hline 10 t ha $^{-1}$ & 22,86 a & $6,54 \mathrm{a}$ & 5,33 a \\
\hline 20 t ha $^{-1}$ & 21,79 a & 5,39 a & 4,64 a \\
\hline $40 \mathrm{t} \mathrm{ha}^{-1}$ & 21,38 a & $5,28 \mathrm{a}$ & 5,11 a \\
\hline Média & 20,99 & 5,59 & 4,98 \\
\hline$C V \%$ & 15,65 & 18,54 & 15,51 \\
\hline
\end{tabular}

(1) Médias seguidas de mesma letra, em cada coluna, não diferem entre si ao nível de 5\% de probabilidade pelo teste de Tukey. 
Tabela 28. Teores carbono nas frações resistente (C-resistente), médio (C-médio) e lábil (C-lábil) nas camadas do solo amostradas até $20 \mathrm{~cm}$ de profundidade, cinco anos após a aplicação de biossólido (10, 20 e $\left.40 \mathrm{t} \mathrm{ha}^{-1}\right)$ ou de fertilizantes minerais, em área sob cultivo de eucalipto. Resultados expressos em relação ao total de carbono

\begin{tabular}{|c|c|c|c|}
\hline & \multicolumn{3}{|c|}{ C-resistente $\left(\mathrm{g} \mathrm{kg}^{-1}\right)$} \\
\hline & $0-5 \mathrm{~cm}$ & $5-10 \mathrm{~cm}$ & $10-20 \mathrm{~cm}$ \\
\hline Controle & $42,46 \mathrm{a}^{(1)}$ & 27,09 a & 26,46 a \\
\hline Fert. Mineral & 47,11 a & 38,07 a & 31,85 a \\
\hline $10 \mathrm{t} \mathrm{ha}^{-1}$ & 42,83 a & 33,29 a & 26,67 a \\
\hline $20 \mathrm{t} \mathrm{ha}^{-1}$ & 48,00 a & 31,88 a & 33,75 a \\
\hline $40 \mathrm{t} \mathrm{ha}^{-1}$ & 32,70 a & 37,50 a & 28,09 a \\
\hline Média & 42,61 & 33,56 & 29,36 \\
\hline \multirow[t]{2}{*}{ CV\% } & 26,62 & 32,50 & 24,15 \\
\hline & \multicolumn{3}{|c|}{ C-médio ( $\mathrm{g} \mathrm{kg}^{-1}$ ) } \\
\hline Controle & 11,96 a & 23,13 a & 25,62 a \\
\hline Fert. Mineral & 11,36 a & 10,25 a & 21,92 a \\
\hline $10 \mathrm{t} \mathrm{ha}^{-1}$ & 11,12 a & $16,05 \mathrm{a}$ & 21,64 a \\
\hline $20 \mathrm{t} \mathrm{ha}^{-1}$ & 9,16 a & $18,52 \mathrm{a}$ & $23,53 \mathrm{a}$ \\
\hline $40 \mathrm{t} \mathrm{ha}^{-1}$ & 13,80 a & 17,66 a & 22,41 a \\
\hline Média & 11,48 & 17,12 & 23,03 \\
\hline \multirow[t]{2}{*}{$C V \%$} & 22,87 & 60,97 & 33,40 \\
\hline & \multicolumn{3}{|c|}{ C-lábil (g kg-1) } \\
\hline Controle & 45,58 a & 49,78 a & 47,91 a \\
\hline Fert. Mineral & 41,53 a & 51,68 a & $46,22 \mathrm{a}$ \\
\hline 10 t ha $^{-1}$ & 46,05 a & 50,66 a & 51,69 а \\
\hline 20 t ha $^{-1}$ & 42,84 a & 49,59 a & $42,72 \mathrm{a}$ \\
\hline $40 \mathrm{t} \mathrm{ha}^{-1}$ & 53,50 a & 44,84 a & 49,50 a \\
\hline Média & 45,90 & 49,31 & 47,61 \\
\hline$C V \%$ & 19,79 & 10,46 & 13,32 \\
\hline
\end{tabular}

${ }^{(1)}$ Médias seguidas de mesma letra, em cada coluna, não diferem entre si ao nível de 5\% de probabilidade pelo teste de Tukey. 


\subsubsection{Compostos orgânicos}

Os teores de açúcares solúveis em água, proteína bruta, lipídeos, celulose e lignina, determinados nas amostras de solo (0-5, 5-10 e 10-20 cm) coletadas cinco anos após a aplicação de biossólido ou de fertilizantes minerais, são apresentados nas Tabelas 29, 30, 31, 32 e 33, respectivamente. Não foi detectada a presença de hemicelulose nas amostras.

Tabela 29. Teores de açúcares solúveis nas camadas do solo amostradas até $20 \mathrm{~cm}$ de profundidade, cinco anos após a aplicação de biossólido (10, 20 e 40 t ha ${ }^{-1}$ ) ou de fertilizantes minerais, em área sob cultivo de eucalipto. Resultados expressos na massa seca e em relação ao total de matéria orgânica

\begin{tabular}{|c|c|c|c|}
\hline & \multicolumn{3}{|c|}{ Açúcares solúveis $\left(\mathrm{g} \mathrm{kg}^{-1}\right)$} \\
\hline & $0-5 \mathrm{~cm}$ & $5-10 \mathrm{~cm}$ & $10-20 \mathrm{~cm}$ \\
\hline Controle & $0,38 \mathrm{a}^{(1)}$ & $0,29 \mathrm{a}$ & $0,26 \mathrm{a}$ \\
\hline Fert. Mineral & $0,41 \mathrm{a}$ & $0,27 \mathrm{a}$ & $0,28 \mathrm{a}$ \\
\hline $10 \mathrm{t} \mathrm{ha}^{-1}$ & $0,42 \mathrm{a}$ & $0,30 \mathrm{a}$ & $0,23 \mathrm{a}$ \\
\hline 20 t ha $^{-1}$ & 0,34 a & 0,29 a & $0,30 \mathrm{a}$ \\
\hline $40 \mathrm{t} \mathrm{ha}^{-1}$ & 0,33 a & $0,28 \mathrm{a}$ & $0,26 \mathrm{a}$ \\
\hline Média & 0,37 & 0,29 & 0,27 \\
\hline \multirow[t]{2}{*}{$C V \%$} & 26,02 & 21,30 & 16,48 \\
\hline & \multicolumn{3}{|c|}{ Açúcares solúveis (\% MO) } \\
\hline Controle & $0,45 \mathrm{a}$ & $1,52 \mathrm{a}$ & $1,53 \mathrm{a}$ \\
\hline Fert. Mineral & $0,58 \mathrm{a}$ & $1,60 \mathrm{a}$ & 1,66 a \\
\hline $10 \mathrm{t} \mathrm{ha}^{-1}$ & 0,48 a & $1,42 \mathrm{a}$ & 1,36 a \\
\hline $20 \mathrm{t} \mathrm{ha}^{-1}$ & $0,45 \mathrm{a}$ & $1,51 \mathrm{a}$ & $1,60 \mathrm{a}$ \\
\hline 40 t ha $^{-1}$ & $0,50 \mathrm{a}$ & $1,41 \mathrm{a}$ & 1,46 a \\
\hline Média & 0,50 & 1,49 & 1,52 \\
\hline CV\% & 29,73 & 26,58 & 19,25 \\
\hline
\end{tabular}

Não houve diferença entre os tratamentos para os teores de açúcares solúveis (Tabela 29), proteína bruta (Tabela 30), lipídeos (Tabela 31) e celulose (Tabela 32) no solo. Os teores médios de açúcares solúveis foram iguais a 0,37 ; 0,29 , e $0,27 \mathrm{~g} \mathrm{~kg}^{-1}$ de 
solo seco, respectivamente para as camadas 0-5, 5-10 e 10-20 cm, representando de 0,5 a $1,5 \%$ do total de MO (Tabela 29). Esses baixos valores estão de acordo com a literatura (Stevenson, 1994; Saviozzi et al., 1999), pois as concentrações de açúcares simples no solo são resultado de um delicado balanço entre síntese e degradação pelos microrganismos edáficos, influenciados por fatores como: umidade, temperatura e oferta de substrato energético (Stevenson, 1994).

A concentração média de proteína bruta na camada $0-5 \mathrm{~cm}$ foi 2,5 vezes maior que nas duas outras camadas, com valor médio de 10,63 $\mathrm{g} \mathrm{kg}^{-1}$ de solo seco (Tabela 30). Embora o teor de proteína expressa na massa seca de solo tenha diminuído com a profundidade, a participação no total de MO aumentou 13,54 \%, na camada 0-5 cm, e 24,94 \%, na camada 10-20 cm, o que indica maior quantidade de compostos orgânicos nitrogenados na MO presente em profundidade. Utilizando a abundância natural do isótopo de carbono ${ }^{13} \mathrm{C}$, tem-se observado que a movimentação de compostos orgânicos para camadas mais profundas no solo, enriquecendo-as em MO, é um processo extremamente lento, com predomínio, em profundidade, de uma MO mais antiga (Balesdent \& Mariotti, 1996). Considerando que a MO apresenta redução da relação C/N inicial, geralmente superior a 30 em resíduos vegetais, tendendo a valores de 10 a 12 , função de processos aeróbios de decomposição com perda parcial de $\mathrm{C}$ na forma de $\mathrm{CO}_{2}$ e manutenção do N (Stevenson, 1986), a MO em profundidade deve ter valores de relação $\mathrm{C} / \mathrm{N}$ mais estreitos, devido ao aumento da participação relativa de compostos orgânicos nitrogenados no total de MO do solo. Isso é confirmado pelos valores de $\mathrm{C} / \mathrm{N}$ até $20 \mathrm{~cm}$, apresentados na Tabela 22.

Os teores de lipídeos nas amostras de solo não diferiram entre os tratamentos, para as três profundidades avaliadas (Tabela 31), e foram inferiores aos valores médios citados por Stevenson (1994), entre 1,23 e 6,24 \% do total de MO. Lipídeos em biossólidos são citados como um dos principais componentes da MO desses resíduos orgânicos (Hohla et al., 1978; Terry et al., 1979a; Rowell et al., 2001), mas, apesar disso, após cinco anos da aplicação do biossólido nenhuma diferença entre os tratamentos foi observada (Tabela 31). Hohla et al. (1978) verificaram em um solo que recebeu aplicações sucessivas de biossólido durante seis anos, num total de $298 \mathrm{t} \mathrm{ha}^{-1}$ (base seca), 
que 11,9 \% do C-orgânico estava presente em óleos e graxas, enquanto que no solo controle, o C presente em óleos e graxas foi somente 1,7 \%, concluindo que a aplicação do biossólido proporcionou acúmulo dessas substâncias. Deve-se ressaltar que no trabalho de Hohla et al (1978) o biossólido utilizado apresentou concentração de 17 \% do total de MO do resíduo como óleos e graxas, além das quantidades e freqüência de aplicação serem muito diferentes do experimento aqui investigado. O biossólido alcalino utilizado no presente trabalho apresentou apenas 7,5 \% do total de MO como lipídeos (ver Tabela 9, capítulo 3) e a dose máxima do resíduo aplicada no campo, uma única vez, foi de $40 \mathrm{t} \mathrm{ha}^{-1}$. As concentrações de lipídeos em alguns solos dos Estados Unidos e Canadá foram relacionados a vegetação e o pH do solo, ou a combinação de ambos. Solos sob vegetação de coníferas, com baixo valor de $\mathrm{pH}$ e teor reduzido de cálcio (Spodosols) exibiram naturalmente maiores teores de lipídeos, em comparação a solos bem drenados sob floresta (Alfisols), com pH relativamente mais alto e bem supridos em cálcio (Stevenson, 1996).

Os teores de celulose no solo também não exibiram diferenças entre os tratamentos, após cinco anos da aplicação do biossólido (Tabela 32). Em média, nas camadas 0-5, 5-10 e 10-20 cm, os teores de celulose foram iguais a 52,89; 14,64 ; e $13,26 \mathrm{~g} \mathrm{~kg}^{-1}$ de solo seco. Na camada $0-5 \mathrm{~cm}$, o teor de celulose foi cerca de 4 vezes superior aos valores das outras duas camadas avaliadas, porém a participação do composto orgânico no total de MO aumentou com a profundidade. Apesar dos carboidratos, incluindo celulose e hemicelulose, constituírem os principais compostos orgânicos ou macromoléculas presentes na MO de solos (Camargo et al., 1999), podendo representar até 50 \% do total de carbono orgânico (Sposito, 1989), os valores aqui apresentados são um pouco elevados, considerando que as quantidade de celulose representou, sozinha, mais de $60 \%$ do total de MO, independente da profundidade (Tabela 32). Esse fato pode estar relacionado as análises químicas utilizadas. Procedimentos analíticos baseados na susceptibilidade de hidrólise ou extração à diferentes soluções (ácidas, neutras ou alcalinas, com ou sem fonte externa de calor, etc.) na realidade não separam ou quantificam entidades químicas definidas, mas sim, compostos orgânicos com características de solubilidade e afinidades químicas comuns 
(Stevenson, 1994). Desse modo, quantidades substanciais de outros compostos podem estar fazendo parte do compartimento aqui denominado celulose. Análises químicas dessa natureza, aplicadas a amostras vegetais, têm sido incapazes de separar totalmente a lignina de outros compostos como alguns carboidratos, taninos e cutinas (Prescott \& Preston, 1994; Coûteaux et al., 1995; Preston et al., 1997), mas, de modo geral, definem compostos com baixa biodegradabilidade no ambiente, como são a lignina, os taninos e as cutinas (Brady \& Weill, 2002). Embora se esperasse teores baixos de hemicelulose, por ser facilmente degradada no solo (Brady \& Weill, 2002), sua ausência nas amostras também pode ser atribuída ao tipo de análise.

Tabela 30. Teores de proteína bruta nas camadas do solo amostradas até $20 \mathrm{~cm}$ de profundidade, cinco anos após a aplicação de biossólido (10, 20 e 40 t ha ${ }^{-1}$ ) ou de fertilizantes minerais, em área sob cultivo de eucalipto. Resultados expressos na massa seca e em relação ao total de matéria orgânica

\begin{tabular}{|c|c|c|c|}
\hline & \multicolumn{3}{|c|}{ Proteína bruta $\left(\mathrm{g} \mathrm{kg}^{-1}\right)$} \\
\hline & $0-5 \mathrm{~cm}$ & $5-10 \mathrm{~cm}$ & $10-20 \mathrm{~cm}$ \\
\hline Controle & $10,74 \mathrm{a}^{(1)}$ & $3,72 \mathrm{a}$ & $4,51 \mathrm{a}$ \\
\hline Fert. Mineral & 9,51 a & $3,00 \mathrm{a}$ & 3,68 a \\
\hline $10 \mathrm{t} \mathrm{ha}^{-1}$ & 11,62 a & $3,84 \mathrm{a}$ & $5,06 \mathrm{a}$ \\
\hline $20 \mathrm{t} \mathrm{ha}^{-1}$ & 10,98 a & $3,37 \mathrm{a}$ & $4,75 \mathrm{a}$ \\
\hline $40 \mathrm{t} \mathrm{ha}^{-1}$ & 10,29 a & 3,59 a & 4,15 a \\
\hline Média & 10,63 & 3,51 & 4,43 \\
\hline \multirow[t]{2}{*}{$C V \%$} & 24,11 & 14,38 & 29,19 \\
\hline & \multicolumn{3}{|c|}{ Proteína bruta (\% MO) } \\
\hline Controle & 12,77 a & 19,02 a & 25,30 a \\
\hline Fert. Mineral & 12,67 a & 17,86 a & 22,20 a \\
\hline $10 \mathrm{t} \mathrm{ha}^{-1}$ & 13,41 a & 17,57 a & 29,30 a \\
\hline $20 \mathrm{t} \mathrm{ha}^{-1}$ & 14,31 a & 18,07 a & 24,50 a \\
\hline $40 \mathrm{t} \mathrm{ha}^{-1}$ & 14,52 a & 17,85 a & 23,41 a \\
\hline Média & 13,54 & 18,07 & 24,94 \\
\hline$C V \%$ & 8,34 & 9,89 & 28,47 \\
\hline
\end{tabular}

$\overline{(1)}$ Médias seguidas de mesma letra, em cada coluna, não diferem entre si ao nível de $5 \%$ de probabilidade pelo teste de Tukey. 
Tabela 31. Teores de lipídeos nas camadas do solo amostradas até $20 \mathrm{~cm}$ de profundidade, cinco anos após a aplicação de biossólido (10, 20 e 40 t ha ${ }^{-1}$ ) ou de fertilizantes minerais, em área sob cultivo de eucalipto. Resultados expressos na massa seca e em relação ao total de matéria orgânica

\begin{tabular}{|c|c|c|c|}
\hline & \multicolumn{3}{|c|}{ Lipídeos ( g kg $^{-1}$ ) } \\
\hline & $0-5 \mathrm{~cm}$ & $5-10 \mathrm{~cm}$ & $10-20 \mathrm{~cm}$ \\
\hline Controle & $0,27 \mathrm{a}^{(1)}$ & $0,13 \mathrm{a}$ & 0,05 a \\
\hline Fert. Mineral & $0,46 \mathrm{a}$ & $0,12 \mathrm{a}$ & $0,07 \mathrm{a}$ \\
\hline 10 t ha $^{-1}$ & 0,38 a & 0,16 a & 0,08 a \\
\hline 20 t ha $^{-1}$ & $0,41 \mathrm{a}$ & 0,09 a & $0,11 \mathrm{a}$ \\
\hline 40 t ha $^{-1}$ & $0,23 \mathrm{a}$ & $0,09 \mathrm{a}$ & 0,09 a \\
\hline Média & 0,35 & 0,12 & 0,08 \\
\hline \multirow[t]{2}{*}{$C V \%$} & 68,24 & 48,80 & 31,18 \\
\hline & \multicolumn{3}{|c|}{ Lipídeos (\% MO) } \\
\hline Controle & $0,32 \mathrm{a}$ & $0,72 \mathrm{a}$ & 0,29 a \\
\hline Fert. Mineral & 0,59 a & $0,67 \mathrm{a}$ & $0,45 \mathrm{a}$ \\
\hline 10 t ha $^{-1}$ & $0,43 \mathrm{a}$ & 0,67 a & $0,44 \mathrm{a}$ \\
\hline 20 t ha $^{-1}$ & $0,44 \mathrm{a}$ & $0,48 \mathrm{a}$ & 0,57 a \\
\hline $40 \mathrm{t} \mathrm{ha}^{-1}$ & $0,31 \mathrm{a}$ & $0,43 \mathrm{a}$ & $0,50 \mathrm{a}$ \\
\hline Média & 0,42 & 0,60 & 0,45 \\
\hline$C V \%$ & 30,94 & 30,43 & 28,00 \\
\hline
\end{tabular}

A lignina foi o único composto orgânico que apresentou diferença na MO do solo em função dos tratamentos e, somente, na camada $0-5 \mathrm{~cm}$ (Tabela 33). Nessa camada, o maior teor de lignina foi observado na MO do solo do tratamento $40 \mathrm{t} \mathrm{ha}^{-1}$ de biossólido, que diferiu estatisticamente dos teores observados no Controle e demais doses de biossólido. O teor médio de lignina na camada $0-5 \mathrm{~cm}$ do solo do tratamento Fert. Mineral foi intermediário entre o maior valor (40 $\mathrm{t} \mathrm{ha}^{-1}$ de biossólido) e os menores valores (demais tratamentos). Portanto, os tratamentos Fert. Mineral e $40 \mathrm{t} \mathrm{ha}^{-1}$ de biossólido se destacaram dos demais. O enriquecimento da MO do solo com lignina nesses tratamentos pode ser explicado pela maior deposição de folhas, em relação aos 
demais, bem como pela natureza desse composto. No período de 12 meses, de setembro de 1999 a agosto de 2000, foram observadas quantidades acumuladas de deposição de folhas iguais a 4,7 e 3,4 $\mathrm{t} \mathrm{ha}^{-1}$, nos tratamentos $40 \mathrm{t} \mathrm{ha}^{-1}$ de biossólido e Fert. Mineral, respectivamente, cerca de 1,7 a 2,3 vezes superior ao valor do Controle, e também superiores as quantidades depositadas nos demais tratamentos (Guedes, 2000). De acordo com Guedes ${ }^{4}$, essa tendência de maior deposição de folhas nos tratamentos $40 \mathrm{t} \mathrm{ha}^{-1}$ de biossólido e Fert. Mineral se manteve nos meses que se seguiram, até cinco anos após a aplicação do biossólido, inclusive com quantidades médias mais próximas, devido a um aumento relativo de deposição no tratamento Fert. Mineral. No entanto, somente a maior deposição de folhas não explica a diferença verificada para a lignina, pois outros compostos orgânicos deveriam, do mesmo modo, ter acumulado MO do solo a 0-5 cm de profundidade. Deve-se, nesse aspecto, considerar também a natureza dos compostos orgânicos. A lignina é, numa escala de biodegradabilidade, praticamente a última das macromoléculas presentes em tecidos vegetais a ser decomposta no ambiente (Brady Weill, 2002), que, juntamente com compostos fenólicos solúveis, são parcialmente estabilizados por processos bio-físico-químicos, formando substâncias humificas (Camargo et al., 1999). A recalcitrância da lignina no ambiente está relacionada principalmente um tipo de ligação química que une os blocos de fenil propano da molécula, são as do tipo carbono-carbono, extremamente resistentes a degradação química (Mason, 1980). Pode-se presumir, então, que outros compostos do folhedo depositado sobre o solo, facilmente degradados pela microbiota, foram mantidos em patamares mais ou menos constantes, sem praticamente interferência da quantidade de folhas depositada, em detrimento ao acúmulo relativo de lignina, função da quantidade do material vegetal depositado e da natureza recalcitrante desse composto. Respeitando a mesma linha de raciocínio, outros compostos de natureza recalcitrante, como alguns lipídeos (Stevenson, 1986), podem também ter se acumulado na MO do solo. No entanto, em função de concentrações originalmente baixas no material vegetal, por exemplo 2 \% para lipídeos (Brady \& Weill, 2002), e condições de alta variabilidade associada a

\footnotetext{
${ }^{4}$ GUEDES, M.C. Comunicação pessoal, 2004.
} 
medidas relacionadas a MO do solo (Lefroy et al., 1993), tais alterações, menos contrastantes, devem ter sido mascaradas.

Tabela 32. Teores de celulose nas camadas do solo amostradas até $20 \mathrm{~cm}$ de profundidade, cinco anos após a aplicação de biossólido (10, 20 e 40 t ha ${ }^{-1}$ ) ou de fertilizantes minerais, em área sob cultivo de eucalipto. Resultados expressos na massa seca e em relação ao total de matéria orgânica

\begin{tabular}{|c|c|c|c|}
\hline & \multicolumn{3}{|c|}{ Celulose $\left(\mathrm{g} \mathrm{kg}^{-1}\right)$} \\
\hline & $0-5 \mathrm{~cm}$ & $5-10 \mathrm{~cm}$ & $10-20 \mathrm{~cm}$ \\
\hline Controle & $57,30 \mathrm{a}^{(1)}$ & 13,70 a & $13,72 \mathrm{a}$ \\
\hline Fert. Mineral & 46,21 a & 11,90 a & 11,84 a \\
\hline $10 \mathrm{t} \mathrm{ha}^{-1}$ & 61,08 a & 17,06 a & $13,32 \mathrm{a}$ \\
\hline 20 t ha $^{-1}$ & 57,45 a & 14,39 a & 14,80 a \\
\hline $40 \mathrm{tha}^{-1}$ & 42,39 a & 16,12 a & $12,62 \mathrm{a}$ \\
\hline Média & 52,89 & 14,64 & 13,26 \\
\hline \multirow[t]{2}{*}{ CV\% } & 32,74 & 22,23 & 20,04 \\
\hline & \multicolumn{3}{|c|}{ Celulose (\% MO) } \\
\hline Controle & 68,11 a & 69,33 a & 77,69 a \\
\hline Fert. Mineral & 59,83 a & 70,61 a & 70,05 a \\
\hline $10 \mathrm{t} \mathrm{ha}^{-1}$ & 69,31 a & 77,57 a & 75,43 a \\
\hline $20 \mathrm{t} \mathrm{ha}^{-1}$ & 72,59 a & 76,22 a & 77,36 a \\
\hline $40 \mathrm{t} \mathrm{ha}^{-1}$ & 60,05 a & 76,58 a & 71,14 a \\
\hline Média & 65,98 & 74,06 & 74,34 \\
\hline CV\% & 16,42 & 7,73 & 5,39 \\
\hline
\end{tabular}

Os dois índices de qualidade da MO, ILC e relação Lignina/N, não evidenciaram qualquer alteração da qualidade do componente orgânico presente no solo dos tratamentos, após cinco anos da aplicação do biossólido ou de fertilizantes minerais (Tabela 34). Embora a lignina esteja incorporada nos dois índices e se tenha verificado certa tendência de destaque dos valores desse composto no solo dos tratamentos $40 \mathrm{t} \mathrm{ha}^{-1}$ de biossólido e Fert. Mineral, a elevada variação dos dados (ver valores de CV\% na 
Tabela 34) impediu que as diferenças fossem estatisticamente distintas, não permitindo maiores especulações a respeito desses resultados.

Tabela 33. Teores de lignina nas camadas do solo amostradas até $20 \mathrm{~cm}$ de profundidade, cinco anos após a aplicação de biossólido (10, 20 e $40 \mathrm{t} \mathrm{ha}^{-1}$ ) ou de fertilizantes minerais, em área sob cultivo de eucalipto. Resultados expressos na massa seca e em relação ao total de matéria orgânica

\begin{tabular}{|c|c|c|c|}
\hline & \multicolumn{3}{|c|}{ Lignina $\left(\mathrm{g} \mathrm{kg}^{-1}\right)$} \\
\hline & $0-5 \mathrm{~cm}$ & $5-10 \mathrm{~cm}$ & $10-20 \mathrm{~cm}$ \\
\hline Controle & $6,95 \mathrm{a}^{(1)}$ & $1,17 \mathrm{a}$ & $0,58 \mathrm{a}$ \\
\hline Fert. Mineral & $12,14 \mathrm{a}$ & 1,13 a & 0,38 a \\
\hline $10 \mathrm{tha}^{-1}$ & $7,26 \mathrm{a}$ & $0,82 \mathrm{a}$ & $0,38 \mathrm{a}$ \\
\hline $20 \mathrm{tha}^{-1}$ & $4,77 \mathrm{a}$ & $0,48 \mathrm{a}$ & $0,53 \mathrm{a}$ \\
\hline $40 \mathrm{tha}^{-1}$ & 15,39 a & $1,01 \mathrm{a}$ & $0,32 \mathrm{a}$ \\
\hline Média & 9,30 & 0,92 & 0,44 \\
\hline \multirow[t]{2}{*}{$C V \%$} & 72,86 & 63,08 & 61,09 \\
\hline & \multicolumn{3}{|c|}{ Lignina (\% MO) } \\
\hline Controle & $8,18 \mathrm{~b}$ & 6,69 a & 3,15 a \\
\hline Fert. Mineral & $13,99 a b$ & $6,91 \mathrm{a}$ & $2,25 \mathrm{a}$ \\
\hline $10 \mathrm{tha}^{-1}$ & $8,14 \mathrm{~b}$ & 3,57 a & $2,13 \mathrm{a}$ \\
\hline $20 \mathrm{t} \mathrm{ha}^{-1}$ & $5,20 \mathrm{~b}$ & $2,60 \mathrm{a}$ & 2,79 a \\
\hline $40 \mathrm{tha}^{-1}$ & 21,18 a & 4,47 a & $1,80 \mathrm{a}$ \\
\hline Média & 11,34 & 4,85 & 2,42 \\
\hline CV\% & 42,99 & 69,74 & 51,99 \\
\hline
\end{tabular}


Tabela 34. Índice lignocelulósico (ILC) e relação Lignina/N da matéria orgânica presente nas amostras de solo coletadas em diferentes camadas até $20 \mathrm{~cm}$ de profundidade, cinco anos após a aplicação de biossólido (10, 20 e $40 \mathrm{t} \mathrm{ha}^{-1}$ ) ou de fertilizantes minerais, em área sob cultivo de eucalipto.

\begin{tabular}{|c|c|c|c|}
\hline & \multicolumn{3}{|c|}{ ILC } \\
\hline & $0-5 \mathrm{~cm}$ & $5-10 \mathrm{~cm}$ & $10-20 \mathrm{~cm}$ \\
\hline Controle & $0,11 \mathrm{a}^{(1)}$ & $0,08 \mathrm{a}$ & $0,04 \mathrm{a}$ \\
\hline Fert. Mineral & $0,20 \mathrm{a}$ & 0,09 a & 0,03 a \\
\hline $10 \mathrm{tha}^{-1}$ & $0,11 \mathrm{a}$ & $0,04 \mathrm{a}$ & $0,02 \mathrm{a}$ \\
\hline $20 \mathrm{t} \mathrm{ha}^{-1}$ & $0,07 \mathrm{a}$ & $0,03 \mathrm{a}$ & 0,03 a \\
\hline $40 \mathrm{t} \mathrm{ha}^{-1}$ & $0,26 \mathrm{a}$ & $0,05 \mathrm{a}$ & $0,02 \mathrm{a}$ \\
\hline Média & 0,15 & 0,06 & 0,03 \\
\hline \multirow[t]{2}{*}{ CV\% } & 44,03 & 70,38 & 51,23 \\
\hline & \multicolumn{3}{|c|}{ Lignina/N } \\
\hline Controle & 3,96 a & $2,34 \mathrm{a}$ & 0,94 a \\
\hline Fert. Mineral & $6,92 \mathrm{a}$ & $2,27 \mathrm{a}$ & $0,62 \mathrm{a}$ \\
\hline $10 \mathrm{t} \mathrm{ha}^{-1}$ & $4,13 \mathrm{a}$ & $1,65 \mathrm{a}$ & $0,62 \mathrm{a}$ \\
\hline $20 \mathrm{tha}^{-1}$ & $2,72 \mathrm{a}$ & $0,97 \mathrm{a}$ & $0,87 \mathrm{a}$ \\
\hline $40 \mathrm{t} \mathrm{ha}^{-1}$ & 8,77 a & $2,02 \mathrm{a}$ & 0,52 a \\
\hline Média & 5,30 & 1,85 & 0,72 \\
\hline$C V \%$ & 72,86 & 63,15 & 61,26 \\
\hline
\end{tabular}

\subsubsection{Capacidade de troca catiônica (CTC)}

Os resultados de CTC são apresentados na Tabela 35. Pode-se notar que não foi verificado efeito dos tratamentos nos valores determinados de $\mathrm{CTC}_{7}$. Em média os valores foram iguais a 80,68 ; 36,73 e 38,25 $\mathrm{mmol}_{\mathrm{c}} \mathrm{kg}^{-1}$ de solo seco. Tais valores foram próximos aos apresentados por Andrade \& Mattiazzo (2000) e Vaz (2000), para períodos de avaliação até 12 meses da aplicação do biossólido. Nesses trabalhos os autores não determinaram diretamente a $\mathrm{CTC}_{7}$, esta foi calculada pela soma dos teores de $\mathrm{Ca}, \mathrm{Mg}, \mathrm{K}$ e $\mathrm{H}+\mathrm{Al}$ nas amostras de solo. Como os teores de $\mathrm{C}$ no solo foram iguais 
entre os tratamentos, a $\mathrm{CTC}_{7}$ somente poderia ter variado em função da qualidade da MO, o que parece não ocorreu.

Tabela 35. Resultados de capacidade de troca catiônica determinada em pH igual a 7,0 $\left(\mathrm{CTC}_{7}\right)$ e no valor natural de $\mathrm{pH}\left(\mathrm{CTC}_{\text {efetiva}}\right)$, a partir de amostras de solo coletadas em três profundidades, até $20 \mathrm{~cm}$, cinco anos após a aplicação de biossólido (10, 20 e $40 \mathrm{t} \mathrm{ha}^{-1}$ ) ou de fertilizantes minerais, em área sob cultivo de eucalipto

\begin{tabular}{|c|c|c|c|c|c|c|}
\hline \multirow[t]{2}{*}{ Tratamento } & \multicolumn{3}{|c|}{$\mathrm{CTC}_{7}\left(\mathrm{mmol}_{\mathrm{c}} \mathrm{kg}^{-1}\right)$} & \multicolumn{3}{|c|}{$\mathrm{CTC}_{\text {efetiva }}\left(\mathrm{mmol}_{\mathrm{c}} \mathrm{kg}^{-1}\right)$} \\
\hline & $0-5 \mathrm{~cm}$ & $5-10 \mathrm{~cm}$ & $10-20 \mathrm{~cm}$ & $0-5 \mathrm{~cm}$ & $5-10 \mathrm{~cm}$ & $10-20 \mathrm{~cm}$ \\
\hline Controle & $90,26 \mathrm{a}^{(1)}$ & 44,12 a & $34,01 \mathrm{a}$ & $53,58 \mathrm{bc}$ & $48,71 \mathrm{~b}$ & $58,91 \mathrm{ab}$ \\
\hline Fert. Mineral & 76,13 a & 31,42 a & $38,01 \mathrm{a}$ & 49,50 c & $52,38 \mathrm{ab}$ & $55,85 \mathrm{~b}$ \\
\hline $10 \mathrm{t} \mathrm{ha}^{-1}$ & 80,30 a & 34,71 a & 35,56 a & 61,24 bc & $55,22 \mathrm{ab}$ & $59,72 \mathrm{ab}$ \\
\hline $20 \mathrm{t} \mathrm{ha}^{-1}$ & 78,41 a & 38,18 a & $42,72 \mathrm{a}$ & $64,80 \mathrm{~b}$ & $60,59 \mathrm{ab}$ & $62,38 \mathrm{ab}$ \\
\hline $40 \mathrm{t} \mathrm{ha}^{-1}$ & 78,28 a & $35,22 \mathrm{a}$ & 40,97 a & 80,88 a & 62,99 a & 67,06 a \\
\hline Média & 80,68 & 36,73 & 38,25 & 62,00 & 55,98 & 60,78 \\
\hline$C V \%$ & 24,38 & 15,14 & 13,69 & 8,65 & 9,83 & 6,10 \\
\hline
\end{tabular}

${ }^{1)}$ Médias seguidas de mesma letra, em cada coluna, não diferem entre si ao nível de 5\% de probabilidade pelo teste de Tukey.

De maneira geral, os resultados de $\mathrm{CTC}_{\text {efetiva }}$ foram influenciados pelos tratamentos (Tabela 35). Nas três camadas avaliadas houve tendência de aumento dos valores de $\mathrm{CTC}_{\text {efetiva }}$ com a aplicação do biossólido. Os aumentos de $\mathrm{CTC}_{\text {efetiva }}$ acompanharam os incrementos de $\mathrm{pH}$ no solo (Tabela 36). Aumentos de $\mathrm{pH}$ foram verificados desde os seis meses da aplicação do resíduo, porém, esses incrementos foram modestos, da ordem de 0,2 a 0,7 , em relação ao solo Controle (Vaz \& Gonçalves, 2002). Aos trinta e dois meses da aplicação, os valores de pH nos tratamentos 10, 20 e $40 \mathrm{t} \mathrm{ha}^{-1}$ de biossólido foram aumentados, respectivamente, em 1,0 ; 2,2 e 2,5 unidades em relação ao valor de 3,6 verificado antes da instalação do experimento (Rocha, 2002). Os valores de pH no solo tratado com doses do biossólido, após cinco anos da aplicação do resíduo, foram, em média, inferiores aos determinados aos 32 meses por Rocha (2002), porém mantiveram-se diferenças significativas entre os valores de pH na maior 
dose de biossólido aplicada e os valores determinados no Controle e/ou Fert, Mineral, à depender da camada amostrada. A diminuição da acidez em solos tratados com biossólidos alcalinos é função principal da quantidade de carbonatos presentes nesse tipo de resíduo.

Tabela 36. Resultados de $\mathrm{pH}$ em $\mathrm{CaCl}_{2}$ nas amostras de solo coletadas em três profundidades, até 20 cm, cinco anos após a aplicação de biossólido (10, 20 e $40 \mathrm{t} \mathrm{ha}^{-1}$ ) ou de fertilizantes minerais, em área sob cultivo de eucalipto

\begin{tabular}{llll}
\hline & \multicolumn{3}{c}{$\mathbf{p H}_{\mathrm{CaCl} 2}$} \\
\hline Controle & $\mathbf{0 - 5} \mathbf{~} \mathbf{m}$ & $\mathbf{5 - 1 0} \mathbf{~} \mathbf{m}$ & $\mathbf{1 0 - 2 0} \mathbf{~} \mathbf{m}$ \\
Fert. Mineral & $3,25 \mathrm{c}^{(1)}$ & $3,77 \mathrm{bc}$ & $3,72 \mathrm{c}$ \\
$10 \mathrm{t} \mathrm{ha}^{-1}$ & $3,22 \mathrm{c}$ & $3,72 \mathrm{c}$ & $3,70 \mathrm{c}$ \\
$20 \mathrm{t} \mathrm{ha}^{-1}$ & $3,82 \mathrm{ab}$ & $3,92 \mathrm{abc}$ & $3,72 \mathrm{c}$ \\
$40 \mathrm{t} \mathrm{ha}^{-1}$ & $4,60 \mathrm{~b}$ & $4,12 \mathrm{ab}$ & $3,97 \mathrm{~b}$ \\
Média & $5,75 \mathrm{a}$ & $4,27 \mathrm{a}$ & $4,20 \mathrm{a}$ \\
CV\% & 4,13 & 3,96 & 3,86 \\
& 8,74 & 4,04 & 2,47
\end{tabular}

(1) Médias seguidas de mesma letra, em cada coluna, não diferem entre si ao nível de 5\% de probabilidade pelo teste de Tukey.

Para comparar a dependência dos valores de CTC $_{\text {efetiva }}$ com relação aos teores de C no solo e com relação ao pH, foram feitas correlações estatísticas entre essas variáveis. Os resultados das correlações são apresentados na Tabela 37. As correlações de $\mathrm{CTC}_{\text {efetiva }}$ com o teor total de C no solo, bem como com as frações de C-orgânico, não foram significativas a 5\% de probabilidade. Com o pH a correlação foi significativa nas três profundidades estudadas. Isso confirma os resultados de Barreto (1995) e de Oliveira et al. (2002), que encontraram valores de CTC mais relacionados com a alterações do $\mathrm{pH}$, do que com o $\mathrm{C}$ em solos tratados com biossólidos alcalinos, tal qual o utilizado no presente estudo.

Embora não tenha sido objetivo comparar os valores de $\mathrm{CTC}_{\text {efetiva }}$ e $\mathrm{CTC}_{7}$ nesse trabalho, notou-se que tais valores foram relativamente próximos na camada 0-5 cm, e que nas camadas mais profundas a $\mathrm{CTC}_{\text {efetiva }}$ foi, em geral, superior a $\mathrm{CTC}_{7}$ 
(Tabela 35). Isso não era esperado, uma vez que solos muito intemperizados, como os Latossolos, possuem quantidades apreciáveis de cargas variáveis em função de alguns fatores, dentre eles o pH (Brady \& Weill, 2002). Desse modo, esperava-se valores maiores na determinação da $\mathrm{CTC}_{7}$, que emprega solução de acetato tamponada a

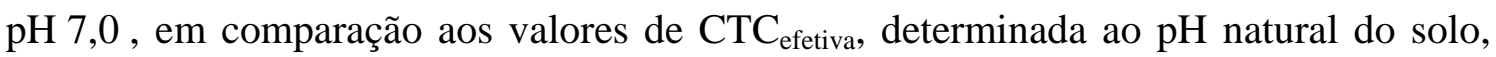
cujo valor máximo foi igual a 5,75 (Tabela 35). Uma possível explicação para esse fato é devido ao uso de diferentes cátions índices nas determinações. Na $\mathrm{CTC}_{7}$ foi utilizado o $\mathrm{NH}_{4}{ }^{+}$como cátion índice, enquanto que na $\mathrm{CTC}_{\text {efetiva }}$ utilizou-se o $\mathrm{K}^{+}$como cátion índice. De acordo com Sumner \& Miller (1996), quando cátions monovalentes como o $\mathrm{NH}_{4}^{+}$e o $\mathrm{Na}^{+}$são utilizados para saturação dos sítios de troca da amostra de solo, reações de hidrólise podem ocorrer, resultando em redução da concentração eletrolítica da solução e perda parcial do cátion índice, subestimando os reais valores. Na Tabela 38 são apresentados os valores de coeficientes de correlação obtidos a partir das correlações estatísticas entre a $\mathrm{CTC}_{7}$ e o teor total de $\mathrm{C}$ e frações de C-orgânico. Excluindo o efeito do $\mathrm{pH}$, que foi mantido constante, os resultados de $\mathrm{CTC}_{7}$ foram dependentes da MO do solo, confirmando a coerência dos resultados, apesar da magnitude dos valores não permitir comparação com a CTC $_{\text {efetiva }}$

Tabela 37. Valores de coefeicientes de correlação obtidos a partir de correlações estatísticas entre os valores de CTC ao $\mathrm{pH}$ natural $\left(\mathrm{CTC}_{\text {efetiva }}\right)$ e os resultados de $\mathrm{pH}$ em $\mathrm{CaCl}_{2}$, teor total de carbono e frações de carbono no solo (C-lábil, C-médio, C-resistente), nas camadas 0-5, 5-10 e 10-20 cm

\begin{tabular}{llll}
\hline & & $\mathbf{C T C}_{\text {efetiva }}$ \\
\hline $\mathbf{p H}_{\mathrm{CaCl} 2}$ & $\mathbf{0 - 5} \mathbf{~ c m}$ & $\mathbf{5 - 1 0} \mathbf{~ m ~}$ & $\mathbf{1 0 - 2 0} \mathbf{~ m ~}$ \\
C-total & $0,787^{* *}$ & $0,621^{* *}$ & $0,633^{* *}$ \\
C-resistente & 0,159 & 0,210 & 0,244 \\
C-médio & 0,056 & 0,054 & 0,147 \\
C-lábil & 0,193 & 0,235 & 0,105 \\
\hline
\end{tabular}

* Significativo a $5 \%$ de probabilidade.

** Significativo a $1 \%$ de probabilidade. 
Tabela 38. Valores de coeficientes de correlação obtidos a partir de correlações estatísticas entre os valores de CTC determinada a $\mathrm{pH}$ 7,0 ( $\left.\mathrm{CTC}_{7}\right)$ e o teor total de carbono e frações de carbono no solo (C-lábil, C-médio, Cresistente), nas camadas 0-5, 5-10 e 10-20 cm

\begin{tabular}{llll}
\hline & \multicolumn{3}{c}{$\mathbf{C T C}_{\mathbf{7}}$} \\
\hline C-total & $\mathbf{0 - 5} \mathbf{~ c m}$ & $\mathbf{5 - 1 0 ~} \mathbf{~ m}$ & $\mathbf{1 0 - 2 0} \mathbf{~ c m}$ \\
C-resistente & $0,542^{*}$ & $-0,186$ & $0,470^{*}$ \\
C-médio & 0,418 & $-0,456$ & $0,513^{*}$ \\
C-lábil & $0,576^{*}$ & $0,666^{* *}$ & 0,221 \\
& $0,475^{*}$ & 0,165 & 0,043 \\
\hline
\end{tabular}

* Significativo a $5 \%$ de probabilidade.

** Significativo a $1 \%$ de probabilidade.

\subsection{Conclusões}

Os teores totais de carbono e nitrogênio no solo, bem como a densidade do solo, após cinco anos da aplicação de doses de um biossólido alcalino ou de fertilizantes minerais, não foram influenciadas pelos tratamentos. Por conseguinte, também não houve contribuição do biossólido ou da fertilização mineral nos estoques de C e $\mathrm{N}$ no solo. A qualidade da matéria orgânica (MO) foi afetada somente na camada 0-5 cm do solo, nos tratamentos com a dose de $40 \mathrm{t} \mathrm{ha}^{-1}$ de biossólido e na fertilização mineral, evidenciando enriquecimento da MO em lignina, função provavelmente da maior deposição de folhas sobre o solo desses tratamentos e da natureza recalcitrante do composto considerado. 


\section{CONCLUSÕES GERAIS}

Os resultados obtidos nos dois estudos que compõe este trabalho permitem concluir que a matéria orgânica (MO) de biossólidos é predominantemente recalcitrante, com a fração facilmente biodegradável exaurida em poucos dias após aplicação no solo, tornando o restante do processo de decomposição do material relativamente mais lento, em comparação a primeira fase. O compartimento protéico representou de 25 a 46 \% do total de MO dos biossólidos e, além da importância quantitativa, desempenhou papel fundamental e crescente com o tempo de incubação, na degradação dos resíduos no solo, podendo-se indicar essa variável como promissora para a previsão da taxa de degradação de biossólidos. No campo, cinco anos após aplicação de um biossólido alcalino, superficialmente, sem incorporação, em solo cultivado com eucalipto, não se verificou efeito das doses do resíduo nos teores e estoques de $\mathrm{C}$ e $\mathrm{N}$ do solo, bem como na qualidade da MO. Houve efeito indireto da maior dose de biossólido (40 $\mathrm{t} \mathrm{ha}^{-1}$ ) no teor de lignina da MO do solo $(0-5 \mathrm{~cm})$, mais enriquecida nesse composto, como também foi observado no tratamento que recebeu fertilizantes minerais, não sendo, portanto, efeito exclusivo do resíduo e dose considerada. 


\section{REFERÊNCIAS BIBLIOGRÁFICAS}

AJWA, H.A.; TABATABAI, M.A. Decomposition of different organic materials in soils. Biology and Fertility of Soils, v.18, p.175-182, 1994.

ALBIACH, R.; CONET, R.; POMARES, F.; INGELMO, F. Organic matter componets, aggregate stability and biological activity in a horticultural soil fertilized with different rates of two sewage sludges during tem years. Bioresouce Technology, v.77, n.2, p.109-114, 2001.

ALTAFIN, L.; ANDRADE, C.A.; MATTIAZZO, M.E. Modelos de cinética no estudo de degradação da fração orgânica de biossólidos após adição ao solo (compact disc). - In: CONGRESSO BRASILEIRO DE CIÊNCIA DO SOLO, 29., Ribeirão Preto, 2003. Resumos. Ilha Solteira: SBCS; UNESP, FCA, 2003. (CD).

ANDRADE, C.A. Nitratos e metais pesados em solos e plantas de Eucalyptus grandis após aplicação de biossólidos da ETE Barueri. Piracicaba, 1999. 65p. Dissertação (Mestrado) - Escola Superior de Agricultura “Luiz de Queiroz”, Universidade de São Paulo.

ANDRADE, C.A.; OLIVEIRA, C.; LIMONGE, F.C.; MATTIAZZO, M.E. Frações de carbono orgânico oxidável de biossólidos e taxas de degradação dos resíduos após aplicação no solo (compact disc). In: ENCONTRO CIENTÍFICO DOS PÓS-GRADUANDOS NO CENA-USP, 9., Piracicaba, 2003. Resumos. Piracicaba: CENA, 2003.

ANDRADE, C.A.; MATTIAZZO, M.E. Nitratos e metais pesados no solo e nas árvores após aplicação de biossólido (lodo de esgoto) em plantações florestais de Eucalyptus grandis. Scientia Forestalis, n.58, p.59-72, 2000.

ANJOS, A.R.M. Lixiviação de espécies químicas em Latossolos sucessivamente tratados com biossólido e disponibilidade de metais pesados para plantas de milho. Piracicaba, 1999. 191p. Tese (Doutorado) - Escola Superior de Agricultura "Luiz de Queiroz”, Universidade de São Paulo. 
ASSOCIATION OF OFFICIAL ANALYTICAL CHEMISTS. Official methods of analysis of the AOAC. 16.ed. Arlington, 1995. v.1, p.4/1-4/30.

AYUSO, M.; HERNANDEZ, T.; GARCIA, C.; COSTA, F. Utilización d'un lodo aerobio como sustitutivo de fertilizantes fosforados inorgánicos. Suelo y Planta, v.2, p.271-280, 1992.

BALESDENT, J.; MARIOTTI, A. Measurement of soil organic matter turnover using ${ }^{13} \mathrm{C}$ natural abundance. In: BOUTTON, T.W.; YAMASAKI, S. Mass spectrometry of soils. New York: Marcel Dekker, 1996. cap.3, p.83-111.

BARRETO, M.C.V. Degradação da fração orgânica de diferentes resíduos e efeitos em algumas propriedades químicas e físicas de dois solos. Piracicaba, 1995. 106p. Tese (Doutorado) - Escola Superior de Agricultura “Luiz de Queiroz”, Universidade de São Paulo.

BAYER, C.; MIELNICZUK, J. Dinâmica e função da matéria orgânica. In: SANTOS, G.A.; CAMARGO, F.A.O. Fundamentos da matéria orgânica do solo: ecossistemas tropicais \& subtropicais. Porto Alegre: Gêneses, 1999. p.9-26.

BERNAL, M.P.; PAREDES, C.; SÁNCHEZ-MONEDERO, M.A.;CEGARRA, J. Maturity and stability parameters of composts prepared with a wide range of organic wastes. Bioresource Technology, v.63, p.91-99, 1998b.

BERNAL, M.P.; SÁNCHEZ-MONEDERO, M.A.; PAREDES, C.; ROIG, A. Carbon mineralization from organic wastes at different composting stages during their incubation with soil. Agriculture, Ecosystems and Environment, v.69, p.175-189, 1998a.

BERTOLDI, M.; VALLINI, G.; PERA, A.; ZUCCONI, F. Technological aspects of composting including modeling and microbiology. In: GASSER, J.K.R. (Ed.). Composting of agricultural and other wastes. London: Elsevier, 1984. p.27-41.

BERTONCINI, E.I. Comportamento de $\mathrm{Cd}$, $\mathrm{Cr}, \mathrm{Cu}$, $\mathrm{Ni}$ e $\mathrm{Zn}$ em Latossolos sucessivamente tratados com biossólido: extração seqüencial, fitodidponibilidade e caracterização de substâncias húmicas. Piracicaba, 2002. 195p. Tese (Doutorado) Escola Superior de Agricultura “Luiz de Queiroz”, Universidade de São Paulo. 
BERTONCINI, E.I. Mobilidade de metais pesados em solos tratados com lodo de esgoto. Piracicaba, 1997. 90p. Dissertação (Mestrado) - Escola Superior de Agricultura “Luiz de Queiroz”, Universidade de São Paulo.

BETTIOL, W.; CAMARGO, O.A. Impacto ambiental do uso agrícola do lodo de esgoto. Jaguariúna: EMBRAPA Meio Ambiente, 2000. 312p.

BETTIOL, W.; CAMARGO, O.A. Prefácio In: BETTIOL, W.; CAMARGO, O.A. (Ed.). Impacto ambiental do uso agrícola de lodo de esgoto. Jaguariúna: EMBRAPA Meio Ambiente, 2000. p.5-6.

BLAIR, G.J.; CHAPMAN, L.; WHITBREAD, A.M.; BALL-COELHO, B.; LARSEN, P.; TIESSEN, H. Soil carbon changes resulting from sugarcane thash management at two locations in Queensland, Australia, and in North-East Brazil. Australian Journal of Soil Research, v.36, p.873-881, 1998.

BLAIR, G.J.; LEFROY, R.D.B.; LISLE, L. Soil carbon fractions based on their degree of oxidation, and the development of a carbon management index for agricultural systems. Austrian Journal of Agricultural Research, v.46, p.1459-1466, 1995.

BLUM, W.E.H. Basic concepts: degradation, resilience, and rehabilitation. In: LAL, R.; BLUM, W.E.H.; VALENTINE, C.; STEWART, B.A. Methods for assessment of soil degradation. Boca Raton: CRC Press, cap.1, p-1-16, 1997.

BOYD, S.A.; SOMMERS, L.E.; NELSON, D.W. Changes in the humic acid fraction of soil resulting from sludge application. Soil Science Society of America Journal, v.44, p.1179-1186, 1980.

BOYLE, M.; PAUL, E.A. Carbon and nitrogen mineralization kinectcs in soil previously amended with sewage sludge. Soil Science Society of America Journal, v.53, p.99-103, 1989.

BRADY, N. C Natureza e propriedades do solo. 7. ed. Rio de Janeiro: Freitas Bastos, 1989. 878p.

BRADY, N.; WEIL, R.R. The nature and properties of soils. 13. ed. Upper Saddle River: Prentice Hall, 2002. 960p.

BROADBENT, F.E. The soil organic fraction. Advances in Agronomy, v.5, p.153-183, 1953. 
BUBB, K.A.; XU, Z.H.; SIMPSON, J.A.; SAFFIGNA, P.G. Some nutrient dynamics associated with litterfall and litter decomposition in hoop pine plantations of southeast Queensland, Australia. Forest Ecology and Management, 110: 343-352, 1998.

CAMARGO, F.A.O.; SANTOS, G.A.; GUERRA, J.G.M. Macromoléculas e substâncias húmicas. In: SANTOS, G.A.; CAMARGO, F.A.O. (Eds.). Fundamentos da material orgânica do solo: ecossistemas trpicais e subtropicais. Porto Alegre: Gênesis, 1999. cap.3, p.27-40.

CANELLAS, L.P.; SANTOS,G.A.; MORAES, A.A.; RUMJANEK, V.M.; OLIVARES, F.L. Avaliação de características de ácidos húmicos de resíduos de origem urbana: I.Métodos espectroscópicos (UV-Vis, IV, $\mathrm{RMN}^{13} \mathrm{C}-\mathrm{CP} / \mathrm{MAS}$ ) e microscopia eletrônica de varredura. Revista Brasileira de Ciência do Solo, v.24, p.741-750, 2000.

CARMO, J.B. Impacto da aplicação de biossólidos nas atividades microbianas do solo. Piracicaba, 2000. 105p. Dissertação (Mestrado) - Escola Superior de Agricultura “Luiz de Queiroz”, Universidade de São Paulo.

CASTELLANOS, J.Z.; PRATT, P.F. Mineralization of manure nitrogen - correlation with laboratory indexes. Soil Science Society of America Journal, v.45, p.354357, 1981.

CAVALLARO, N.; PADILLA, N.; VILLARRUBIA, J. Sewage sludge effects on chemical properties of acid soils. Soil Science, v.156, n.2, p.63-70, 1993.

CERRI, C.C. Dinâmica da matéria orgânica do solo no agroecossitema cana-de-açúcar. Piracicaba, 1986. 197p. Tese (Livre-Docência) - Escola Superior de Agricultura “Luiz de Queiroz”, Universidade de São Paulo.

CHAE, Y.M.; TABATABAI, M.A. Sulfolipid and phospholipid in soils and sewage sludges in Iowa. Soil Science Society of America Journal, v.45, p.20-25, 1981.

CHAN, K.Y.; BOWMAN, A.; OATES, A. Oxidizible organic carbon fractions and soil quality changes in a oxic paleustalf under different pasture leys. Soil Science, v.166, n.1, p.61-67, 2001. 
CIAVATTA, C.; ANTISARI, L.V.; SEQUI, P. Determination of organic carbon in soils and fertilizers. Communications in Soil Science and Plant Analysis, v.20, p.759-773, 1989.

COMPANHIA DE TECNOLOGIA DE SANEAMENTO AMBIENTAL. Aplicação de biossólido em áreas agrícolas: critérios para projeto e operação (Manual Técnico). São Paulo, 1999. 35p.

CONTEH, A.; BLAIR, G.J.; ROCHESTER, I.J. Soil organic carbon fractions in a Vertisol under irrigated cotton production as affected by burning and incorporating cotton stubble. Australian Journal of Soil Research, v.36, p.655-667, 1998.

CORTEZ, J.; DEMARD, J.M.; BOTTNER, P.; MONROZIER, L.J. Decompisition of mediterranean leaf litters: a microcosm experiment investigating relationships between decomposition rates and litter quality. Soil Biology and Biochemistry, v.28, n.5, p.443-452, 1996.

COÛTEAUX, M.M.; BOTTER, P.; BERG, B. Litter decomposition, climate and litter quality. Tree, v.10, n.2, p.63-66, 1995.

DAVID, A.C. Secagem térmica de lodo de esgoto. Determinação da umidade de equilíbrio. São Paulo, 2002. 151p. Dissertação (Mestrado) - Escola Politécnica, Universidade de São Paulo.

DEIANA, S.; GESSA, C.; MANUNZA, B.; RAUSA, R.; SEEBER, R. Analytical and spectroscopic characterization of humic acids extracted from sewage sludge, manure and worm compost. Soil Science, v.150, n.1, p.419-424, 1990.

DİAZ-BURGOS, M.A.; POLO, A. Variaciones de la fracción orgánica durante el compostaje de lodos de depuradoras. Suelo y Planta, v.1, p.453-466, 1991.

DORAN, J.W.; PARKIN, T.B. Defining and assessing soil quality. In: DORAN, J.W.; COLEMAN, D.F.; BEZDICEK, D.F.; STEWART, B.A. Defining soil quality for a sustainable environment. 2 ed. Madison: Soil Science Society of America, cap.1, p.3-22, 1994.

EATON, A.D.; CLESCERI, L.S.; GREENBERG, A.E. Standard methods for the examination of water and wastewater. 19.ed. Washington: American Public Health Association; American Water Works Association; Water Environment Federation, 1995. 533p. 
ESTADOS UNIDOS. Environmental Protection Agency. EPA 625/10-84-003. Environmental regulations and technology : use and dispoal of municipal wastewater sludge. Federal Register, p.15-16, 1984.

ESTADOS UNIDOS. Environmental Protection Agency. Title 40 CRF - Part 503. Final rules: standards for the use or disposal of sewage sludge. Federal Register, v.58, n.32, p.9387-9415, 1993.

ESWARAN, H.; VAN DER BERG, E.; REICH, P. Organic carbon in soils of the world. Soil Science Society of Ameria Journal, v.57, p.192-194, 1993.

FARIA, L.C. Fertilização de povoamentos de eucalipto com biossólido da ETE de Barueri, SP: demanda potencial e nível mínimo de resposta. Piracicaba, 2000. 85p. Dissertação (Mestrado) - Escola Superior de Agricultura “Luiz de Queiroz”, Universidade de São Paulo.

FARIA, L.C.; RODRIGUEZ, L.C.E. Aplicabilidade do biossólido em plantações florestais: 5-Avaliação do potencial de uso do resíduo da ETE de Barueri, SP. In: BETTIOL, W.; CAMARGO, O.A. (Ed.). Impacto ambiental do uso agrícola do lodo de esgoto. Jaguariúna: Embrapa, 2000. p.209-213.

FEIGL, B.J.; MELILLO, J.; CERRI, C.C. Changes in the origin and quality of soil organic matter after pasture introduction in Rondônia (Brazil). Plant and Soil, n.175, p.21-29, 1995.

FRANCO-HERNÁNDEZ, O.; MCKELLIGAN-GONZALEZ, A.N.; LOPEZ-OLGUIN, A.M.; ESPINOSA-CERON, F.; ESCAMILLA-SILVA, E.; DENDOOVEN, L. Dynamics of carbon, nitrogen and phosphorus in soil amended with irradiated, pasteurized and limed biosolids. Bioresouce Technology, v.87, p.93-102, 2003.

GERZABEK, M.H.; HABERHAUER, G.; KIRCHMANN, H. Soil orgânica matter pools and carbon-13 natural abundances in particle-size fractions of a long-term agricultural field experiment receiving organic amandments. Soil Science Society of America Journal, v.65, p.352-358, 2001.

GIBSON, T.S.; CHAN, K.Y.; SHARMA, G. SHEARMAN, R. Soil carbon sequestration utilising recycled organics. Sydney: NSW Agriculture, 2002. 95p.

GILMOUR, J.T.; ROMAN, F.; CLARK, M.D. Decomposition of biosolids in a disposal site soil. Journal of Environmental Quality, v.25, p.1083-1086, 1996b. 
GILMOUR, T.J.; CLARK, M.D.; DANIEL, S.M. Predicting long-term decomposition of biosolids with a seven day test. Journal of Environmental Quality, v.25, p.766-770, 1996a.

GLÓRIA, N.A. Resíduos industriais como fonte de matéria orgânica. In: ENCONTRO SOBRE MATÉRIA ORGÂNICA DO SOLO: PROBLEMAS E SOLUÇÕES, Botucatu, 1992. Botucatu: UNESP, Faculdade de Ciências Agronômicas, 1992. p.129-148.

GLÓRIA, N.A.; CATANI, R.A.; MATUO, T. A determinação da capacidade de troca de cátions do solo pelo método do EDTA. Revista de Agricultura, v.40, p.195198, 1965.

GONÇALVES, J.L.M.; BARROS, N.F.; NAMBIAR, E.K.S.; NOVAIS, R.F. Soil and stand manadement for short-rotation plantations. In: NAMBIAR, S.; BROWN, A. (Ed.). Management of soil, nutrients and water in tropical plantation forests. Camberra: ACIAR, CSIRO, CIFOR, 1997. cap.11, p.379-418.

GONÇALVES, J.L.M.; STAPE, J.L.; BENEDETTI, V.; FESSEL, V.A.G.; GAVA, J.L. Reflexos do cultivo mínimo e intensidade do solo em sua fertilidade e na nutrição das árvores. In: GONÇALVES, J.L.M.; BENEDETTI, V. (Ed.). Nutrição e fertilização florestal. Piracicaba: IPEF, 2000. cap.1, p.1-57.

GREENLAND, D.J.; OADES, J.M. Saccharides. In: GIESEKING, J.E. Soil components: organic components. New York: Springer-Verlag, 1975. v.1, cap.2, p.213-304.

GUEDES, M.C. Efeito do lodo de esgoto (biossólido) sobre a nutrição, ciclagem de nutrients e crescimento de sub-bosque, em plantação de eucalipto. Piracicaba, 2000. 74p. Dissertação (Mestrado) - Escola Superior de Agricultura “Luiz de Queiroz”, Universidade de São Paulo.

GUEDES, M.C.; POGGIANI, F. Variação dos teores de nutrientes foliares em eucalipto fertilizado com biossólido. Scientia Forestalis, n.63, p.188-201, 2003.

HANKIN, L.; HILL, D.E. Proportion of bacteria in agricultural soils able to procedure degradative enzymes. Soil Science, v.126, p.40-43, 1978. 
HATTORI, H.; MUKAI, S. Decomposition of sewage sludges in soil as affected by their organic matter composition. Soil Science and Plant Nutrition, v.32, n.3, p.421-432, 1986.

HEANES, D.L. Determination of total organic-C in soils by improved chromic acid digestion and spectrophotometric procedure. Communications in Soil Science and Plant Analysis, v.15, p.1191-1213, 1984.

HERNÁNDEZ, M.T.; MORENO, J.I.; COSTA, F.; GONZÁLEZ-VILA, F.J.; FRÜND, R. Structural features of humic acidlike substances from sewage sludges. Soil Science, v.149, n.2, p.63-68, 1990.

HERNÁNDEZ-APAOLAZA, L.; , GASCÓ, J.M.; GUERRERO, F. Initial organic matter transformation of soil amended with composted sewage sludge. Biology and Fertility of Soils, v.32, p.421-426, 2000.

HOHLA, G.N.; JONES, R.L.; HINESLY, T.D. The effect of anaerobically digested sewage sludge on organic fractions of blount silt loam. Journal of Environmental Quality, v.7, n.4, p.559-563, 1978.

HSIEH, Y.P.; DOUGLAS, L.A.; MOTTO, H.L. Modeling sewage sludge decomposition in soil: I. Organic carbon transformation. Journal of Environmental Quality, v.10, n.1, p.54-58, 1981.

IAKIMENKO, O.; OTABBONG, E.; SADOVNIKOVA, L.; PERSSON, J.; NILSSON, I.; ORLOV, D.; AMMOSOVA, Y. Dynamic transformation of sewage sludge and farmyard manure components. 1 . Content of humic substances and mmineralisation of organic carbon and nitrogen in incubated soils. Agriculture, Ecosystems and Environment, v.58, p.121-126, 1996.

IPCC, OECD, IEA. Revised 1996 IPCC Guidelines for National Greenhouse Gas Inventories. Bracknell: UK, 1997.

JAMALUDHEEN, V.; KUMAR, B.M. Litter of multipurpose trees in Kerala, India: variations in the amosut, quality, decay rates and release of nutrients. Forest Ecology and Management, n.115, p.1-11, 1999.

JAMES, B.R.; ASCHMANN, S.G. Soluble phosphorus in a forest soil Ap horizon amended with municipal wastewater sludge or compost. Communications in Soil Science and Plant Analisys, v.23, n.7-8, p.861-875, 1992. 
JANZEN, H.H.; KUCEY, R.M.N. C, N, and S mineralization of crop residues as influenced by crop species and nutrient regime. Plant and Soil, v.106, p.35-41, 1988.

JENKINSON, D.S.; ADAMS, D.E.; WILD, A. Model estimates of $\mathrm{CO}_{2}$ emissions from soil in response to global warming. Nature, v.351, p.304-306, 1991.

JOHNSTON, A.E. Soil organic carbon, effects on soils and crops. Soil Use Management, v.2, p.97-105, 1986.

JORGE, J.A.; CAMARGO, O.A.; VALADARES, J.M.A.S. Condições físicas de um Latossolo Varmelho-Escuro quatro anos após aplicação de lodo de esgoto e calcário. Revista Brasileira de Ciência do Solo, v.15, p.237-240, 1991.

KARLEN, D.L.; ANDREWS, S.S.; DORAN, J.W. Soil quality: current concepts and applications. Advances in Agronomy, v.74, p.1-40, 2001.

KARLEN, D.L.; MAUSBACH, M.J.; DORAN, J.W.; CLINE, R.G.; HARRIS, R.F.; SCHUMAN, G.E. Soil quality: a concept, definition, and framework for evaluation. Soil Science Society of America Journal, v.61, p.4-10, 1997.

KOUTIKA, L.S.; ANDREUX, F.; HASSINK, J.; CHONÉ, TH.; CERRI, C.C. Characterization of organic matter in topsoils under rain forest and pasture in the eastern Brazilian Amazon basin. Biology and Fertility os Soils, v.29, p.309-313, 1999.

KUZYAKOV, Y.; FRIEDEL, J.K.; STAHR, K. Review of mechanisms and quantification of priming effects. Soil Biology and Biochemistry, v.32, p.14851498, 2000.

LAVKULICH, L.M. ; WIENS, J.H. Comparison of organic matter destruction by hydrogen peroxide and sodium hypochlorite and its effects on selected mineral constituents . Soil Science Society of America Proceedings, v.34, n.5, p. 755-758, 1970.

LEFROY, R.D.B.; GRAEME, J.B.; STRONG, W.M. Changes in soil organic matter with cropping as measured by organic carbon fractions and ${ }^{13} \mathrm{C}$ natural isotopic abundance. Plant and Soil, v.155/156, p.399-402, 1993. 
LEINWEBER, P.; BLUMENSTEIN, O.; SCHULTEN, H.R. Organic matter composition in sewage farm soils: Investigations by 13C-NMR and pyrolysis-field ionization mass spectrometry. European Journal of Soil Science, v.47, n.1, p.7180, 1996.

LEITA, L.; DE NOBILI, M. Water-soluble fractions of heavy metals during composting of municipal solid waste. Journal of Environmental Quality, v.20, p.73-78, 1991.

LERCH, R.N.; BARBARICK, K.A.; SOMMERS, L.E.; WESTFALL, D.G. Sewage sludge proteins as labile carbon and nitrogen sources. Soil Science Society of America Journal, v.56, p.1470-1476, 1992.

LEVI-MINZI, R.; RIFFALDI, R.; SAVIOZZI, A. Organic matter and nutrients in fresh and mature farmyard manure. Agricultural Wastes, v.16, p.225-236, 1986.

LOEPPERT, R.H.; SUAREZ, D.L. Carbonate and gypsum. In: SPARKS, D.L.; PAGE, A.L.; HELMKE, P.A.; LOEPPERT, R.H.; SOLTANPOUR, P.N.; TABATABAI, M.A.; JOHNSTON, C.T.; SUMNER, M.E. Methods of soil analysis: part 3 Chemical methods. Madison: Soil Science Society of America, American Society of Agronomy, 1996. Cap.15. p.437-476.

LOLL, M.J.; BOLLAG. Protein tranformation in soil. Advances in Agronomy, v.36, p.351-382, 1983.

MAGESAN, G.N.; WANG, H. Application of municipal and industrial residuals in New Zealand forests: an overview. Australian Journal of Soil Research, v.41, p.557-569, 2003.

MARCIANO, C.R. Alterações nos atributos físico-hídricos do solo pela aplicação de resíduos urbanos. Piracicaba, 1999. 74p. Tese (Doutorado) - Escola Superior de Agricultura “Luiz de Queiroz”, Universidade de São Paulo.

MARQUES, M.O. Incorporação de lodo de esgoto em solo cultivado com cana-deaçúcar. Jaboticabal, 1996. 111p. Tese (Livre Docência) - Faculdade de Ciências Agrárias e Veterinárias, Universidade Estadual Paulista “Júlio de Mesquita Filho”.

MARSTORP, H. Influence of solublecarbohydrates, free aminoacids, and protein content on the decomposition of Lolium multiflorum shoots. Biology and Fertility of Soils, v.21, p.257-263, 1996. 
MARTINS, L.F.S. Configuração do sistema radicular das árvores de Eucalyptus grandis em resposta à aplicação de doses crescentes de biossólido. Piracicaba, 2002. 73p. Dissertação (Mestrado) - Escola Superior de Agricultura "Luiz de Queiroz", Universidade de São Paulo.

MASON, C. F. Decomposição. São Paulo: EPU, EDUSP, 1980. 63p.

MATTIAZZO, M.E.; BARRETO, M.C.V.; RODELLA, A.A. Organic matter kinetics mineralization in soils amended with four diffrent organic wastes (compact disc). In: CONGRESS MONDIAL DE SCIENCE DU SOL, 16., Montpellier, 1998. Actes. Montpellier: ISSS, 1998.

MELFI, A.J.; MONTES, C.R. Impacto dos biossólidos sobre o solo. In: TSUTIYA, M.T.; COMPARINI, J.B.; SOBRINHO, P.A.; HESPANHOL, I.; CARVALHO, P.C.T.; MELFI, A.J.; MELO, W.J.; MARQUES, M.O. (Ed.). Biossólidos na agricultura. São Paulo: SABESP, 2001. cap.9, p.243-272.

MELILLO, J.M.; ABER, J.D.; MURATORE, J.F. Nitrogen and lignin control of hardwood leaf litter decomposition dynamics. Ecology, v.63, p.621-626, 1982.

MELO, J.W.; MARQUES, M.O. Potencial do lodo de esgoto como fonte de nutrientes para as plantas. In: BETTIOL, W.; CAMARGO, O.A. (Ed.). Impacto ambiental do uso agrícola de lodo de esgoto. Jaguariúna: EMBRAPA Meio Ambiente, 2000. cap.5, p.109-142.

MELO, W.J.; MARQUES, M.O.; SANTIAGO, G.; CHELLI, R.A.; LEITE, S.A.S. Efeitos de doses crescentes de lodo de esgoto sobre frações de matéria orgânica e CTC de um Latossolo cultivado com cana-de-açúcar. Revista Brasileira de Ciência do Solo, v.18, p.449-455, 1994.

METZGER, L.; YARON, B. Influence of sludge organic matter on soil physical properties. Advances in Soil Science, v.7, p.141-163, 1987.

METZGER, L.;LEVANON, D.; MINGELGRIN, U. The effect of sewage sludge on soil structural stability: microbiological aspects. Soil Science Society of America Journal, v.51, p.346-351, 1987. 
MITCHELL, M.J. HARTENSTEIN, R.; SWIFT, B.L.; NEUHAUSER, E.F.; AGRAMS, B.I.; MULLIGAN, R.M.; BROWN, B.A.; CRAIG, D.; KAPLAN, D. Effect of different sewage sludges on some chemical and biological characteristics of soil. Journal of Environmental Quality, v.7, p.551-558, 1978.

MOORE, D.M.; REYNOLDS JR. R.C. X-ray diffraction and the identification and analysis of clay minerals. New York: Oxford University Press, 1989. 332p.

MORAL， R.; MORENO-CASELLES， J.; PEREZ-MURCIA， M.D.; PEREZESPINOSA, A.; RUFETE, B.; PAREDES, C. Characterization of the organic matter pool in manure. In: INTERNATIONAL CONFERENCE OF THE RAMIRAN NETWORK, 20., Strbské Pleso, 2002. Proceedings. Strbské Pleso: University of Veterinary Medicine and, Research Institute of Veterinary Medicine, 2002. p.169-172.

MULVANEY, R.L. Nitrogen - inorganic forms. In: BIGHAM, J.M. (Ed.). Methods of soil analysis: chemical methods. Madison: Soil Science Society of America; American Society of Agronomy, 1996. cap.38, p.1123-1184.

NELSON, D.W.; SOMMERS, L.E. A rapid and accurate procedure for estimation on organic carbon in soil. Proceedings of Indiana Academy of Science, v.84, p.456-462, 1975.

NELSON, D.W.; SOMMERS, L.E. Total carbon, organic carbon, and organic matter. In: BIGHAM, J.M. (Ed.). Methods of soil analysis: chemical methods. Madison: Soil Science Society of America; American Society of Agronomy, 1996. cap.34, p.961-1010.

OLAYINKA, D.; ADEBAYO, A.; AMUSAN, A. Evaluation of organic carbon oxidation efficiences of a modified wet combustion and Walkley-Black procedures in Nigerian soils. Communications in Soil Science and Plant Analysis, v.29, n.17-18, p.2749-2756, 1998.

OLIVEIRA, F.C. Disposição de lodo de esgoto e composto de lixo urbano num Latossolo Vermelho-Amarelo cultivado com cana-de-açúcar. Piracicaba, 2000. 247p. Tese (Doutorado) - Escola Superior de Agricultura “Luiz de Queiroz”, Universidade de São Paulo. 
OLIVEIRA, F.C.; MATTIAZZO, M.E.; MARCIANO, C.R.; ROSSETO, R. Efeitos de aplicações sucessivas de lodo de esgoto em um Latossolo Amarelo distrófico cultivado com cana-de-açúcar: carbono orgânico, condutividade elétrica, pH e CTC. Revista Brasileira de Ciência do Solo, v.26, p.505-519, 2002.

PIOTROWSKI, E.G.; VALENTINE, K.M.; PFEFFER, P.E. Solid-state, ${ }^{13} \mathrm{C}$, crosspolarization, "magic-angle" spinning, NMR spectroscopy studies of sewage sludge. Soil Science, v.37, n.3, p.194-203, 1984.

PIRES, A.M.M. Ácidos orgânicos da rizosfera : aspectos qualitativos e quantitativos e fitodisponibilidade de metais pesados originários de biossólidos. Piracicaba, 2003. 94p. Tese (Doutorado) - Escola Superior de Agricultura "Luiz de Queiroz", Universidade de São Paulo.

PIRES, A.M.M. Disponibilidade de Zn e Cu adicionados a solos via lodo de esgoto para plantas de arroz. Piracicaba, 1998. 55p. Dissertação (Mestrado) - Escola Superior de Agricultura "Luiz de Queiroz”, Universidade de São Paulo.

PIRES, A.M.M.; ANDRADE, C.A.; MATTIAZZO, M.E. Degradação da carga orgânica, condutividade elétrica e $\mathrm{pH}$ de um Latossolo tratado com biossólido incorporado ou em superfície (compact disc). In: FERTBIO2002, Rio de Janeiro, 2002. Resumos. Rio de Janeiro: UFRRJ, 2002.

POGGIANI, F.; GUEDES, M.C.; BENEDETTI, V. Aplicabilidade do biossólido em plantações florestais: 1-Reflexos no ciclo de nutrientes. In: BETTIOL, W.; CAMARGO, O.A. (Ed.). Impacto ambiental do uso agrícola do lodo de esgoto. Jaguariúna: Embrapa, 2000. p.163-178.

POLGLASE, P.J.; MYERS, B.J. Tree plantations for recycling effluent and biosolids in Australia. In: ELBRIDGE, K.G.; CROWE, M.P.; OLD, K.M. (Eds.) Environment management: the role of eucalypts and pthers fast growing species. Melbourn: CSIRO, 1995. p.100-109.

PRESCOTT, C.E.; PRESTON, C.M. Nitrogen mineralization and decomposition in Forest floors in adjacent plantations of western red cedar, wetern hemlock, and Douglas-fir. Canadian Journal of Forest Research, v.24, p.2424-2431, 1994. 
PRESTON, C.M.; TROFYMOW, J.A.; SAYER, B.G.; NIU, J. ${ }^{13}$ C nuclear magnetic resonance spectroscopy with cross-polarization and magig-angle spinning investigation of the proximate-analysis fractions used to assess litter quality in decomposition studies. Canadian Journal of Botany, v.75, p.1601-1613, 1997.

RAIJ, B. van; QUAGGIO, J.A. Métodos de análise de solo para fins de fertilidade. Campinas: IAC, 1983. 40p (IAC. Boletim Técnico, 81).

REDDY, K.R.; KHALEEL, R.; OVERCASH, M.R.; Carbon transformation in the land areas receiving organic wastes in relation to nonpoint source pollution: A conceptual model. Journal of Environmental Quality, v.9; p.434-442, 1980.

REEVES, D.W. The role of soil organic matter in maitaining soil quality in continuous cropping systems. Soil and Tillage Research, v.43, p.131-167, 1997.

REINERTSEN, S.A.; ELLIOTT, L.F.; COCHRAN, V.L. CAMPBELL, G.S. Role of availabable carbon and nitrogen in determining the rate of wheat straw decomposition. Soil Biology and Biochemistry, v.16, p.459-464, 1984.

RIFFALDI, R.; SAVIOZZI, A.; LEVI-MINZI, R. Water extracts of fresh and mature farmyard manure. Biological Wates, v.23, p.65-72, 1988.

ROBERTS, J.A.; DANIELS, W.L.; BELL, J.C.; BURGER, J.A. Early stages of mine soil genesis as affected by topsoilimg and organic amendements. Soil Science Society of America Journal, v.52, p.730-738, 1988.

ROCHA, G.N. Monitoramento da fertilidade do solo, nutrição mineral e crescimento de um povoamento de Eucalyptus' grandis fertilizado com biossólido. Piracicaba, 2002. 48p. Dissertação (Mestrado) - Escola Superior de Agricultura "Luiz de Queiroz”, Universidade de São Paulo.

RODELLA, A.A. Métodos de avaliação de materiais orgânicos e efeitos de sua incorporação ao solo sobre a mobilização de macronutrientes. Piracicaba, 1996. 148p. Tese (Livre Docência) - Escola Superior de Agricultura “Luiz de Queiroz”, Universidade de São Paulo.

RODELLA, A.A.; SABOYA, L.V. Calibration for conductimetric determination of carbon dioxide. Soil Biology and Biochemistry, v.31, p.2059-2060, 1999. 
ROWELL, D.M.; PRESCOTT, C.E.; PRESTON, C.M. Decomposition en nitrogen mineralization from biosolids and other organic materials: relationship with initial chemistry. Journal of Environmental Quality, v.30, p.1401-1410, 2001.

RYDIN, E.; OTABBONG, E. Potential release of phosphorus from soil mixed with sewage sludge. Journal of Environmental Quality, v.26, n.2, p.529-534, 1997.

SANTOS, D.S.; ANDRADE, C.A.; MATTIAZZO, M.E. Capacidade de troca catiônica em solos tratados com doses de biossólidos (compact disc). In: CONGRESSO BRASILEIRO DE CIÊNCIA DO SOLO, 29., Ribeirão Preto, 2003. Resumos. Ribeirão Preto: Agromídia Software, 2003.

SANTOS, D.S.; ANDRADE, C.A.; MATTIAZZO, M.E. Degradação da fração orgânica de lodos de esgoto após aplicação no solo (compact disc). In: FERTBIO, Rio de Janeiro, 2002. Resumos. Rio de Janeiro: SBCS; SBM; UFFRJ, 2002.

SANTOS, H.F. Uso agrícola do lodo das estações de tratamento de esgotos (ETEs): subsídios para elaboração de uma norma brasileira. São Paulo, 1996. 74p. Dissertação (Mestrado) - Universidade Mackenzie.

SANTOS, H.F.; GUIMARÃES, M.O.; GIUSTI, P.E.A. Uso de lodo de ETEs em reflorestamentos. In: ENCONTRO TÉCNICO DA ASSOCIAÇÃO DE ENGENHEIROS DA SABESP, São Paulo, 1997. Anais. São Paulo: SABESP, 1997. p.1-23.

SAUNDERS, W.M.H.; WILLIAMS, E.G. Observations on the determination of total organic phosphorus in soil. Journal of Soil Science, v.6, p.254-267, 1955.

SAUVESTY, A.; PAGE, F e HOUT, J. A simple method for extracting plant phenolic compounds. Canadian Journal Forest Research, v.22, p.654-659, 1992.

SAVIOZZI, A.; BIASCI, A.; RIFFALDI, R.; LEVI-MINZI, R. Long-term effects of farmyard manure and sewage sludge on some soil biochemical characteristics. Biology and Fertility of Soils, v.30, n.1-2, p.100-106, 1999.

SCHLESINGER, W.H. Biogeochemistry: an analysis of global change. San Diego: Academic Press., 1996. 359p.

SILVA, C.D.; COSTA, L.M.; MATOS, A.T.; CECON, P.R.; SILVA, D.D. Vermicomposto de lodo de esgoto urbano e bagaço de cana-de-açúcar. Revista Brasileira de Engenharia Agrícola e Ambiental, v.6, n.3, p.487-491, 2002. 
SILVA, F.C. Uso agronômico de lodo de esgoto: efeitos em fertilidade do solo e qualidade da cana-de-açúcar. Piracicaba, 1995. 170p. Tese (Doutorado) - Escola Superior de Agricultura “Luiz de Queiroz”, Universidade de São Paulo.

SIMEONI, L.A.; BARBARICK, K.A.; SABEY, B.R. Effect of small-scale composting of sewage-sludge on heavy metal availability to plants. Journal of Environmental Quality, v.13, n.2, p.264-268, 1984.

SIMONETE, M.A.; KIEHL, J.C.; ANDRADE, C.A.; TEIXEIRA, C.F.A. Efeito do lodo de esgoto em um Argissolo e no crescimento e nutrição de milho. Pesquisa Agropecuária Brasileira, v.38., n.10, p.1187-1195, 2003.

SOARES, M.T.S. taxas de mineralização e de lixiviação do nitrogênio, e alterações da fertilidade de um Latossolo Vermelho-Amarelo degradado e outro não-degradado fertilizados com biossólido e florestados com Eucalyptus grandis. Piracicaba, 2003. 142p. Tese (Doutorado) - Escola Superior de Agricultura “Luiz de Queiroz”, Universidade de São Paulo.

SOMMERS, L.E.; NELSON, D.W.; SILVIERA, D.J. Transformations of carbon, nitrogen, and metals in soils treated with waste materials. Journal of Environmental Quality, v.8, p.287-294, 1979.

SOMMERS, L.E.; NELSON, D.W.; YOST, K.J. Variable nature of the chemical composition of sewage sludge. Journal of Environmental Quality, v.5, n.3, p.303-306, 1976.

SOON, Y.K.; ABBOUD, S. A comparison of some methods for soil organic carbon determination. Communications in Soil Science and Plant Analisys, v.22, p.943954, 1991.

SPOSITO, G. The chemistry of soils. Oxford: Oxford University Press, 1989. 222p.

STEVENSON, F.J. Humus chemistry: genesis, composition, reactions. 2.ed. New York: John Wiley \& Sons, 1994. 496p.

STEVENSON. F.J. Cycles of soil: carbon, nitrogen, phosphorus, súlfur, micronutrients. New York: John Wiley, 1986. 380p.

SUMNER, M.E.; MILLER, W.P. Cation exchange capacity and exchange coefficients. In: SPARKS, D.L. (Ed.) Methods of soil analysis: chemical methods. Madison: Soil Science Society of America, 1996. cap.40, p.1201-1229. 
TAVARES, D. Lodo que vira adubo. Globo Rural, n.210, p.58-61, 2003.

TERRY, R.E.; NELSON, D.W.; SOMMERS, L.E. Carbon cycling during sewage sludge decomposition in soils. Soil Science Society of America Journal, v.43, p.494-499, 1979a.

TERRY, R.E.; NELSON, D.W.; SOMMERS, L.E. Decomposition of anaerobically digested sewage sludge as affected by soil environmental conditions. Journal of Environmental Quality, v.8, p.342-347, 1979b.

TESTER, C.F.; PARR, J.F. Decomposition of sewage sludge compost in soil: IV. Effect of indigenous salinity. Journal of Environmental Quality, v.12, p.123-126, 1983.

TESTER, C.F.; SIKKORA, J.M.; TAYLOR, J.; PARR, J.F. Decomposition of sewage sludge compost in soil. I. Carbon and nitrogen transformations. Journal of Envieronmental Quality, v.6, p.459-463, 1977.

TESTER, C.F.; SIKKORA, J.M.; TAYLOR, J.; PARR, J.F. Decomposition of sewage sludge compost in soil: III. Carbon, nitrogen, and phosphorus transformations in different sized fractions. Journal of Environmental Quality, v.8, n.1, p.79-82, 1979.

TSUTIYA, M.T. Características de biossólidos gerados em estações de tratamento de esgotos. In: TSUTIYA, M.T.; COMPARINI, J.B.; SOBRINHO, P.A.; HESPANHOL, I.; CARVALHO, P.C.T.; MELFI, A.J.; MELO, W.J.; MARQUES, M.O. (Ed.). Biossólidos na agricultura. São Paulo: SABESP, 2001. cap.4, p.89-132.

TSUTYA, M.T. Alternativas de disposição final de biossólidos gerados em estações de tratamento de esgotos. In: BETTIOL, W.; CAMARGO, O.A. (Eds.). Impacto ambiental do uso agrícola de lodo de esgoto. Jaguariúna: EMBRAPA Meio Ambiente, 2000. Cap.4, p.69-106.

VAN SOEST, P.J.; WINE, R.H. Use of detergent in the analisys of farmersfeeds. IV. Determination of plant cell wall constituints. Journal of Association of Official Analytical Chemistry, v.50, p.50-55, 1967.

VAZ, L.M.S. Crescimento inicial, fertilidade do solo e nutrição de um povoamento de Eucalyptus grandis fertilizado com biossólido. Piracicaba, 2000. 41p. Dissertação (Mestrado) - Escola Superior de Agricultura “Luiz de Queiroz”, Universidade de São Paulo. 
VAZ, L.M.S; GONÇALVES, J.L.M. Uso de biossólidos em povoamento de eucalipto: efeito em atributos químicos do solo, no crescimento e na absorção de nutrientes. Revista Brasileira de Ciência do Solo, v.26, n.3, p.747-758, 2002.

VELASCO-MOLINA, M.; MATTIAZZO, M.E. Nitrogênio inorgânico em solo cinco anos após a aplicação de biossólido. In: CONGRESSO BRASILEIRO DE CIÊNCIA DO SOLO, 29., Ribeirão Preto, 2003. Resumos. Ilha Solteira: SBCS; UNESP,FCA, 2003.

VON LÜTZOW, M.; LEIFELD, J.; KAINZ, M.; KÖGEL-KNABNER, I.; MUNCH, J.C. Indicators for soil organic matter quality in soils under different management. Geoderma, v.105, p.243-258, 2002.

WADT, P.G.S.; NOVAIS, R.F. Influência da idade da árvore na interpretação do estado nitricional de Eucalypto grandis, pelos métodos do nível crítico e do DRIS. In: IUFRO CONFERENCE ON SILVICULTURE AND IMPROVEMENT TO EUCALYPT, Salvador, 1997. Proceedings. Salvador: Embrapa Centro Nacional de Pesquisas Florestais, 1997. p.262-268.

WALKER, T.W.; ADAMS, A.F.R. Studies on soil organic matter: 1.Influenece of phosphorus content of parent materials on accumulations of carbon, nitrogen, sulfur, and organic phosphorus in grassland soils. Soil Science, v.85, p.307-318, 1958.

WALKLEY, A.; BLACK, I.A. An examination of the Degtjareff method for determining soil organic matter and a proposed modification of the chromic acid titration method. Soil Science, v.37, p.29-38, 1934.

WARKENTIN, B.P. The changing concept of soil quality. Journal of Soil and Water Conservation, v.50, p.226-228, 1995.

WISEMAN, J.T.; ZIBILSKE, L.M. Effect of sludge application sequence on carbon and nitrogen mineralization in soil. Journal of Environmental Quality, v.17, n.2, p.334-339, 1988.

WONG, J.W.C.; LAI, M.; FANG, M.; MA, K.K. Effect of sewage sludge amendment on soil microbial activity and nutrient mineralization. Environment International, v.24, n.8, p.935-943, 1998. 
APÊNDICES 
Apêndice 1. Valores de coeficiente de correlação (r) obtidos a partir das correlações estatísticas simples entre todas as variáveis expressas em relação ao total de massa seca

\begin{tabular}{|c|c|c|c|c|c|c|c|c|c|c|}
\hline & $\mathrm{MO}$ & C-total & C-org. & C-inorg. & N-total & N-org. & N-inorg. & P-total & P-org. & P-inorg. \\
\hline $\mathrm{MO}$ & ----- & $0,972 * *$ & $0,993 * *$ & $-0,855$ & 0,838 & 0,817 & 0,820 & 0,566 & 0,636 & 0,202 \\
\hline C-total & $0,972 * *$ & ----- & $0,988 * *$ & $-0,728$ & 0,878* & $0,875^{*}$ & 0,720 & 0,628 & 0,710 & 0,206 \\
\hline C-org. & $0,993 * *$ & $0,988 * *$ & ----- & $-0,824$ & 0,834 & 0,821 & 0,764 & 0,557 & 0,654 & 0,145 \\
\hline C-inorg. & $-0,855$ & $-0,728$ & $-0,824$ & ----- & $-0,491$ & $-0,442$ & $-0,761$ & $-0,172$ & $-0,304$ & 0,112 \\
\hline N-total & 0,838 & $0,878 *$ & 0,834 & $-0,491$ & ----- & $0,997 * *$ & 0,814 & $0,922 *$ & $0,903^{*}$ & 0,538 \\
\hline N-org. & 0,817 & $0,875^{*}$ & 0,821 & $-0,442$ & $0,997 * *$ & ----- & 0,767 & $0,926 *$ & $0,906 *$ & 0,538 \\
\hline N-inorg. & 0,820 & 0,720 & 0,764 & $-0,761$ & 0,814 & 0,767 & ----- & 0,701 & 0,689 & 0,424 \\
\hline P-total & 0,566 & 0,628 & 0,557 & $-0,172$ & $0,922 *$ & $0,926 *$ & 0,701 & ----- & $0,918 *$ & 0,682 \\
\hline P-org. & 0,636 & 0,710 & 0,654 & $-0,304$ & 0,903* & $0,906^{*}$ & 0,689 & $0,918 *$ & ----- & 0,338 \\
\hline P-inorg. & 0,202 & 0,206 & 0,145 & 0,112 & 0,538 & 0,538 & 0,424 & 0,682 & 0,338 & ----- \\
\hline C-solúvel & 0,656 & 0,767 & 0,693 & 0,267 & 0,900* & $0,917 *$ & 0,582 & $0,881^{*}$ & $0,975 * *$ & 0,293 \\
\hline C-lábil & 0,578 & 0,463 & 0,576 & 0,863 & 0,058 & 0,019 & 0,337 & $-0,305$ & $-0,079$ & $-0,544$ \\
\hline C-médio & 0,767 & 0,821 & 0,759 & 0,362 & 0,930* & 0,938* & 0,673 & 0,852 & 0,719 & 0,287 \\
\hline C-resistente & $0,940 *$ & $0,982 * *$ & $0,956 * *$ & $-0,649$ & $0,945 * *$ & $0,943 *$ & 0,758 & 0,755 & 0,826 & $-0,343$ \\
\hline Carboidrato & 0,608 & 0,762 & 0,688 & $\begin{array}{l}-0,398 \\
\end{array}$ & 0,550 & 0,574 & 0,256 & 0,364 & 0,655 & 0,246 \\
\hline
\end{tabular}

* Significativo ao nível de $5 \%$ de probabilidade.

** Significativo ao nível de $1 \%$ de probabilidade. 
Apêndice 1. Valores de coeficiente de correlação (r) obtidos a partir das correlações estatísticas simples entre todas as variáveis expressas como porcentagem do conteúdo orgânico (Continuação)

\begin{tabular}{|c|c|c|c|c|c|c|c|c|c|c|}
\hline & $\mathrm{MO}$ & C-total & C-org. & C-inorg. & N-total & N-org. & $\mathrm{N}$-inorg. & P-total & P-org. & P-inorg. \\
\hline Lipídeos & 0,654 & 0,755 & 0,689 & $-0,296$ & $0,887^{*}$ & $0,900 *$ & 0,605 & 0,868 & $0,984^{* *}$ & 0,246 \\
\hline Proteína & 0,816 & $0,870 *$ & 0,820 & $-0,452$ & $0,997 * *$ & $0,998 * *$ & 0,780 & 0,929* & $0,926 *$ & 0,509 \\
\hline Hemicel. & 0,066 & 0,177 & 0,061 & 0,380 & 0,586 & 0,613 & 0,255 & 0,829 & 0,618 & 0,811 \\
\hline Celulose & 0,130 & 0,002 & 0,127 & $-0,561$ & $-0,421$ & $-0,457$ & $-0,065$ & $-0,716$ & $-0,528$ & $-0,701$ \\
\hline Lignina & 0,931* & 0,854 & 0,898* & $-0,868$ & 0,679 & 0,649 & 0,762 & 0,382 & 0,356 & 0,287 \\
\hline Fenóis & 0,483 & 0,392 & 0,488 & $-0,737$ & $-0,069$ & $-0,093$ & 0,133 & $-0,448$ & $-0,283$ & $-0,509$ \\
\hline Taninos & 0,458 & 0,326 & 0,437 & $-0,752$ & $-0,091$ & $-0,127$ & 0,202 & $-0,450$ & $-0,359$ & $-0,369$ \\
\hline $\mathrm{C} / \mathrm{N}$ & $-0,010$ & $-0,152$ & $-0,024$ & $-0,458$ & $-0,542$ & $-0,580$ & $-0,147$ & $-0,792$ & $-0,623$ & $-0,710$ \\
\hline C-lábil/N & $-0,208$ & $-0,361$ & $-0,229$ & $-0,309$ & $-0,668$ & $-0,709$ & $-0,216$ & $-0,830$ & $-0,667$ & $-0,725$ \\
\hline C-médio/N & $-0,546$ & $-0,455$ & $-0,526$ & 0,674 & $-0,481$ & $-0,432$ & $-0,746$ & $-0,394$ & $-0,617$ & 0,184 \\
\hline C-resist/N & 0,830 & 0,815 & 0,857 & $-0,825$ & 0,442 & 0,433 & 0,421 & 0,064 & 0,245 & $-0,271$ \\
\hline Lignina/N & 0,594 & 0,450 & 0,559 & $-0,840$ & 0,088 & 0,046 & 0,390 & $-0,266$ & 0,219 & $-0,188$ \\
\hline ILC & 0,781 & 0,789 & 0,772 & $-0,448$ & $0,960 * *$ & $0,950 * *$ & 0,833 & 0,911* & 0,787 & 0,729 \\
\hline QHL & 0,087 & 0,223 & 0,094 & 0,400 & 0,586 & 0,623 & 0,183 & 0,801 & 0,594 & 0,788 \\
\hline OCR & $-0,029$ & 0,195 & 0,072 & 0,399 & 0,242 & 0,306 & $-0,291$ & 0,321 & 0,476 & $-0,146$ \\
\hline
\end{tabular}

* Significativo ao nível de $5 \%$ de probabilidade.

** Significativo ao nível de $1 \%$ de probabilidade. 
Apêndice 1. Valores de coeficiente de correlação (r) obtidos a partir das correlações estatísticas simples entre todas as variáveis expressas como porcentagem do conteúdo orgânico (Continuação)

\begin{tabular}{|c|c|c|c|c|c|c|c|c|c|c|}
\hline & C-solúvel & C-lábil & C-médio & C-resistente & Carboidratos & Lipídeos & Proteína & Hemicel. & Celulose & Lignina \\
\hline $\mathrm{MO}$ & 0,656 & 0,578 & 0,767 & $0,940 *$ & 0,608 & 0,654 & 0,816 & 0,066 & 0,130 & $0,931^{*}$ \\
\hline C-total & 0,767 & 0,463 & 0,821 & $0,982 * *$ & 0,762 & 0,755 & $0,870^{*}$ & 0,177 & 0,002 & 0,854 \\
\hline C-org. & 0,693 & 0,576 & 0,759 & $0,956 * *$ & 0,688 & 0,689 & 0,820 & 0,061 & 0,127 & $0,898^{*}$ \\
\hline C-inorg. & 0,267 & 0,863 & 0,362 & $-0,649$ & $\begin{array}{l}-0,398 \\
\end{array}$ & $-0,296$ & $-0,452$ & 0,380 & $-0,561$ & $-0,868$ \\
\hline N-total & $0,900 *$ & 0,058 & $0,930 *$ & $0,945 * *$ & 0,550 & $0,887^{*}$ & $0,997 * *$ & 0,586 & $-0,421$ & 0,679 \\
\hline N-org. & 0,917* & 0,019 & $0,938^{*}$ & $0,943^{*}$ & 0,574 & $0,900^{*}$ & $0,998 * *$ & 0,613 & $-0,457$ & 0,649 \\
\hline N-inorg. & 0,582 & 0,337 & 0,673 & 0,758 & 0,256 & 0,605 & 0,780 & 0,255 & $-0,065$ & 0,762 \\
\hline P-total & $0,881^{*}$ & $-0,305$ & 0,852 & 0,755 & 0,364 & 0,868 & 0,929* & 0,829 & $-0,716$ & 0,382 \\
\hline P-org. & $0,975 * *$ & $-0,079$ & 0,719 & 0,826 & 0,655 & $0,984 * *$ & $0,926^{*}$ & 0,618 & $-0,528$ & 0,356 \\
\hline P-inorg. & 0,293 & $-0,544$ & 0,287 & $-0,343$ & 0,246 & 0,246 & 0,509 & 0,811 & $-0,701$ & 0,287 \\
\hline C-solúvel & ----- & $-0,065$ & 0,757 & 0,865 & 0,757 & $0,996 * *$ & 0,930* & 0,601 & $-0,516$ & 0,371 \\
\hline C-lábil & $-0,065$ & ----- & $-0,055$ & 0,328 & 0,385 & $-0,031$ & 0,030 & $-0,774$ & $0,878^{*}$ & 0,622 \\
\hline C-médio & 0,757 & $-0,055$ & ----- & 0,863 & 0,374 & 0,715 & 0,918* & 0,644 & $-0,471$ & 0,706 \\
\hline C-resistente & 0,865 & 0,328 & 0,863 & ----- & 0,729 & 0,855 & $0,944^{*}$ & 0,327 & $-0,158$ & 0,780 \\
\hline Carboidrato & 0,757 & 0,385 & 0,374 & 0,729 & ----- & 0,766 & 0,592 & 0,000 & 0,037 & 0,324 \\
\hline
\end{tabular}

* Significativo ao nível de $5 \%$ de probabilidade.

** Significativo ao nível de $1 \%$ de probabilidade. 
Apêndice 1. Valores de coeficiente de correlação (r) obtidos a partir das correlações estatísticas simples entre todas as variáveis expressas como porcentagem do conteúdo orgânico (Continuação)

\begin{tabular}{|c|c|c|c|c|c|c|c|c|c|c|}
\hline & C-solúvel & C-lábil & C-médio & C-resistente & Carboidratos & Lipídeos & Proteína & Hemicel. & Celulose & Lignina \\
\hline Lipídeos & $0,996 * *$ & $-0,031$ & 0,715 & 0,855 & 0,766 & ----- & $0,918^{*}$ & 0,564 & $-0,483$ & 0,358 \\
\hline Proteína & $0,930 *$ & 0,030 & $0,918^{*}$ & $0,944 *$ & 0,592 & $0,918^{*}$ & ----- & 0,603 & $-0,450$ & 0,634 \\
\hline Hemicel. & 0,601 & $-0,774$ & 0,644 & 0,327 & 0,000 & 0,564 & 0,603 & $\begin{array}{l}---- \\
\end{array}$ & $-0,974 * *$ & $-0,054$ \\
\hline Celulose & $-0,516$ & $0,878^{*}$ & $-0,471$ & $-0,158$ & 0,037 & $-0,483$ & $-0,450$ & $-0,974 * *$ & ----- & 0,274 \\
\hline Lignina & 0,371 & 0,622 & 0,706 & 0,780 & 0,324 & 0,358 & 0,634 & $-0,054$ & 0,274 & ----- \\
\hline Fenóis & $-0,217$ & $0,947 * *$ & $-0,069$ & 0,223 & 0,286 & $-0,207$ & $-0,099$ & $-0,805$ & 0,901* & 0,601 \\
\hline Taninos & $-0,327$ & $0,913^{*}$ & $-0,059$ & 0,156 & 0,083 & $-0,318$ & $-0,137$ & $-0,781$ & 0,896* & 0,644 \\
\hline $\mathrm{C} / \mathrm{N}$ & $-0,629$ & 0,799 & $-0,588$ & $-0,305$ & $-0,091$ & $-0,592$ & $-0,572$ & $-0,986 * *$ & $0,987 * *$ & 0,149 \\
\hline C-lábil/N & $-0,713$ & 0,657 & $-0,749$ & $-0,484$ & $-0,230$ & $-0,664$ & $-0,693$ & $-0,951 * *$ & $0,913^{*}$ & $-0,061$ \\
\hline C-Médio/N & $-0,488$ & $-0,469$ & $-0,148$ & $-0,503$ & $-0,448$ & $-0,558$ & $-0,478$ & 0,090 & $-0,169$ & $-0,354$ \\
\hline C-Resist/N & 0,339 & 0,840 & 0,401 & 0,702 & 0,676 & 0,337 & 0,428 & $-0,405$ & 0,549 & 0,805 \\
\hline Lignina/N & $-0,207$ & 0,888* & 0,120 & 0,296 & 0,079 & $-0,201$ & 0,034 & $-0,642$ & 0,796 & 0,779 \\
\hline ILC & 0,762 & $-0,031$ & $0,960 * *$ & 0,852 & 0,304 & 0,740 & $0,941^{*}$ & 0,645 & $-0,463$ & 0,709 \\
\hline QHL & 0,614 & $-0,759$ & 0,679 & 0,358 & 0,067 & 0,567 & 0,607 & 0,986** & $-0,961^{* *}$ & $-0,031$ \\
\hline OCR & 0,605 & $-0,354$ & 0,183 & 0,272 & 0,676 & 0,585 & 0,313 & 0,400 & $-0,492$ & $-0,322$ \\
\hline
\end{tabular}

* Significativo ao nível de $5 \%$ de probabilidade.

** Significativo ao nível de $1 \%$ de probabilidade. 
Apêndice 1. Valores de coeficiente de correlação (r) obtidos a partir das correlações estatísticas simples entre todas as variáveis expressas como porcentagem do conteúdo orgânico (Continuação)

\begin{tabular}{|c|c|c|c|c|c|c|c|c|c|c|}
\hline & Fenóis & Taninos & $\mathrm{C} / \mathrm{N}$ & C-lábil/N & C-médio/N & C-resist/N & Lignina/N & ILC & QLC & OCR \\
\hline $\mathrm{MO}$ & 0,483 & 0,458 & $-0,010$ & $-0,208$ & $-0,546$ & 0,830 & 0,594 & 0,781 & 0,087 & $-0,029$ \\
\hline C-total & 0,392 & 0,326 & $-0,152$ & $-0,361$ & $-0,455$ & 0,815 & 0,450 & 0,789 & 0,223 & 0,195 \\
\hline C-org. & 0,488 & 0,437 & $-0,024$ & $-0,229$ & $-0,526$ & 0,857 & 0,559 & 0,772 & 0,094 & 0,072 \\
\hline C-inorg. & $-0,737$ & $-0,752$ & $-0,458$ & $-0,309$ & 0,674 & $-0,825$ & $-0,840$ & $-0,448$ & 0,400 & 0,399 \\
\hline N-total & $-0,069$ & $-0,091$ & $-0,542$ & $-0,668$ & $-0,481$ & 0,442 & 0,088 & $0,960 * *$ & 0,586 & 0,242 \\
\hline N-org. & $-0,093$ & $-0,127$ & $-0,580$ & $-0,709$ & $-0,432$ & 0,433 & 0,046 & $0,950 * *$ & 0,623 & 0,306 \\
\hline N-inorg. & 0,133 & 0,202 & $-0,147$ & $-0,216$ & $-0,746$ & 0,421 & 0,390 & 0,833 & 0,183 & $-0,291$ \\
\hline P-total & $-0,448$ & $-0,450$ & $-0,792$ & $-0,830$ & $-0,394$ & 0,064 & $-0,266$ & $0,911^{*}$ & 0,801 & 0,321 \\
\hline P-org. & $-0,283$ & $-0,359$ & $-0,623$ & $-0,667$ & $-0,617$ & 0,245 & 0,219 & 0,787 & 0,594 & 0,476 \\
\hline P-inorg. & $-0,509$ & $-0,369$ & $-0,710$ & $-0,725$ & 0,184 & $-0,271$ & $-0,188$ & 0,729 & 0,788 & $-0,146$ \\
\hline C-solúvel & $-0,217$ & $-0,327$ & $-0,629$ & $-0,713$ & $-0,488$ & 0,339 & $-0,207$ & 0,762 & 0,614 & 0,605 \\
\hline C-lábil & $0,947 * *$ & 0,913* & 0,799 & 0,657 & $-0,469$ & 0,840 & $0,888 *$ & $-0,031$ & $-0,759$ & $-0,354$ \\
\hline C-médio & $-0,069$ & $-0,059$ & $-0,588$ & $-0,749$ & $-0,148$ & 0,401 & 0,120 & $0,960 * *$ & 0,679 & 0,183 \\
\hline C-resistente & 0,233 & 0,156 & $-0,305$ & $-0,484$ & $-0,503$ & 0,702 & 0,296 & 0,852 & 0,358 & 0,272 \\
\hline Carboidrato & 0,286 & 0,083 & $-0,091$ & $-0,230$ & $-0,448$ & 0,676 & 0,079 & 0,304 & 0,067 & 0,676 \\
\hline
\end{tabular}

* Significativo ao nível de $5 \%$ de probabilidade.

** Significativo ao nível de $1 \%$ de probabilidade. 
Apêndice 1. Valores de coeficiente de correlação (r) obtidos a partir das correlações estatísticas simples entre todas as variáveis expressas como porcentagem do conteúdo orgânico (Continuação)

\begin{tabular}{|c|c|c|c|c|c|c|c|c|c|c|}
\hline & Fenóis & Taninos & $\mathrm{C} / \mathrm{N}$ & C-lábil/N & C-médio/N & C-resist/N & Lignina/N & ILC & QLC & OCR \\
\hline Lipídeos & $-0,207$ & $-0,318$ & $-0,592$ & $-0,664$ & $-0,558$ & 0,337 & $-0,201$ & 0,740 & 0,567 & 0,585 \\
\hline Proteína & $-0,099$ & $-0,137$ & $-0,572$ & $-0,693$ & $-0,478$ & 0,428 & 0,034 & $0,941^{*}$ & 0,607 & 0,313 \\
\hline Hemicel. & $-0,805$ & $-0,781$ & $-0,986 * *$ & $-0,951 * *$ & 0,090 & $-0,405$ & $-0,642$ & 0,645 & $0,986 * *$ & 0,400 \\
\hline Celulose & $0,901^{*}$ & $0,896^{*}$ & $0,987 * *$ & 0,913* & $-0,169$ & 0,549 & 0,796 & $-0,463$ & $-0.961 * *$ & $-0,492$ \\
\hline Lignina & 0,601 & 0,644 & 0,149 & $-0,061$ & $-0,354$ & 0,805 & 0,779 & 0,709 & $-0,031$ & $-0,322$ \\
\hline Fenóis & ----- & $0,971^{* *}$ & 0,824 & 0,647 & $-0,163$ & 0,838 & $0,921^{*}$ & $-0,122$ & $-0,750$ & $-0,353$ \\
\hline Taninos & $0,971^{* *}$ & $\begin{array}{l}---- \\
\end{array}$ & 0,836 & 0,676 & $-0,139$ & 0,753 & $0,976 * *$ & $-0,081$ & $-0,747$ & $-0,558$ \\
\hline $\mathrm{C} / \mathrm{N}$ & 0,824 & 0,836 & ----- & $0,964 * *$ & $-0,123$ & 0,409 & 0,724 & $-0,565$ & $-0,986 * *$ & $-0,544$ \\
\hline C-lábil/N & 0,647 & 0,676 & $0,964 * *$ & $\begin{array}{l}---- \\
\end{array}$ & $-0,148$ & 0,176 & 0,554 & $-0,680$ & $-0,984 * *$ & $-0,571$ \\
\hline C-Médio/N & $-0,163$ & $-0,139$ & $-0,123$ & $-0,148$ & ----- & $-0,338$ & $-0,221$ & $-0,359$ & 0,188 & 0,096 \\
\hline C-Resist/N & 0,838 & 0,753 & 0,409 & 0,176 & $-0,338$ & ----- & 0,774 & 0,328 & $-0,332$ & 0,009 \\
\hline Lignina/N & $0,921^{*}$ & $0,976^{* *}$ & 0,724 & 0,554 & $-0,221$ & 0,774 & ----- & 0,123 & $-0,622$ & $-0,611$ \\
\hline ILC & $-0,122$ & $-0,081$ & $-0,565$ & $-0,680$ & $-0,359$ & 0,328 & 0,123 & ----- & 0,634 & 0,044 \\
\hline QHL & $-0,750$ & $-0,747$ & $-0,986 * *$ & $-0,984 * *$ & 0,188 & $-0,332$ & $-0,622$ & 0,634 & ----- & 0,482 \\
\hline OCR & $-0,353$ & $-0,558$ & $-0,544$ & $-0,571$ & 0,096 & 0,009 & $-0,611$ & 0,044 & 0,482 & ----- \\
\hline
\end{tabular}

* Significativo ao nível de $5 \%$ de probabilidade.

** Significativo ao nível de $1 \%$ de probabilidade. 
Apêndice 2. Valores de coeficiente de correlação (r) obtidos a partir das correlações estatísticas simples entre todas as variáveis expressas como porcentagem do conteúdo orgânico

\begin{tabular}{|c|c|c|c|c|c|c|c|c|c|c|c|}
\hline & C-solúv. ${ }^{\text {a }}$ & C-lábil ${ }^{\mathrm{a}}$ & C-médio ${ }^{a}$ & C-resist. ${ }^{a}$ & Açúcares b & $\mathrm{PB}^{\mathrm{b}}$ & Lipíd. $^{b}$ & Hemicel. $^{\text {b }}$ & Celul. $^{\text {b }}$ & Tanin. ${ }^{b}$ & Fenóis $^{b}$ \\
\hline C-solúv. $^{\text {a }}$ & ----- & $-0,853$ & 0,498 & 0,763 & 0,436 & $0,903^{*}$ & $0,987 * *$ & 0,549 & $-0,865$ & $-0,781$ & $-0,786$ \\
\hline C-lábil ${ }^{\text {a }}$ & $-0,853$ & ----- & $-0,691$ & $-0,807$ & $-0,520$ & $-0,895^{*}$ & $-0,764$ & $-0,797$ & $0,919^{*}$ & 0,868 & 0,824 \\
\hline C-médio ${ }^{\mathrm{a}}$ & 0,498 & $-0,691$ & ----- & 0,130 & $-0,224$ & 0,766 & 0,375 & 0,750 & $-0,857$ & $-0,741$ & $-0,852$ \\
\hline C-resist. $^{a}$ & 0,763 & $-0,807$ & 0,130 & ----- & 0,896* & 0,601 & 0,741 & 0,480 & $-0,560$ & $-0,585$ & $-0,433$ \\
\hline Açúcares b & 0,436 & $-0,520$ & $-0,224$ & $0,896^{*}$ & ----- & 0,270 & 0,434 & 0,322 & $-0,192$ & $-0,343$ & $-0,112$ \\
\hline $\mathrm{PB}^{\mathrm{b}}$ & 0,903* & $-0,895^{*}$ & 0,766 & 0,601 & 0,270 & ----- & 0,837 & 0,820 & $-0,978 * *$ & $-0,958 * *$ & $-0,974 * *$ \\
\hline Lipíd. $^{b}$ & 0,987* & $-0,764$ & 0,375 & 0,741 & 0,434 & 0,837 & ----- & 0,429 & $\begin{array}{l}-0,781 \\
\end{array}$ & $-0,696$ & $-0,703$ \\
\hline Hemicel. $^{b}$ & 0,549 & $-0,797$ & 0,750 & 0,480 & 0,322 & 0,820 & 0,429 & ----- & $-0,807$ & $-0,941^{*}$ & $-0,873^{*}$ \\
\hline Celul. $^{b}$ & $-0,865$ & 0,919* & $-0,857$ & $-0,560$ & $-0,192$ & $-0,978 * *$ & $-0,781$ & $-0,807$ & ----- & 0,919* & 0,961* \\
\hline Tanin. ${ }^{b}$ & $-0,781$ & 0,868 & $-0,741$ & $-0,585$ & $-0,343$ & $-0,958 * *$ & $-0,696$ & $-0,941^{*}$ & $-0,919 *$ & ----- & $0,964 * *$ \\
\hline Fenóis ${ }^{b}$ & $\begin{array}{l}-0,786 \\
\end{array}$ & 0,824 & $-0,852$ & $-0,433$ & $-0,112$ & $-0,974 * *$ & $\begin{array}{l}-0,703 \\
\end{array}$ & $-0,873 *$ & $0,961^{*}$ & $0,964 * *$ & ----- \\
\hline
\end{tabular}

${ }^{\mathrm{a}}$ Valores utilizados nas correlações, expressos como porcentagem do total de C-orgânico dos biossólidos.

${ }^{\text {b }}$ Valores utilizados nas correlações, expressos como porcentagem do total de MO dos biossólidos.

* Significativo ao nível de $5 \%$ de probabilidade.

** Significativo ao nível de 1 \% de probabilidade. 